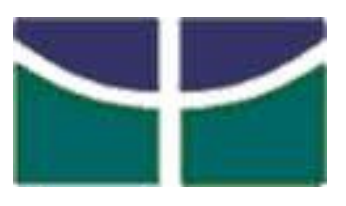

\author{
Universidade de Brasília - UnB \\ Instituto de Ciências Humanas - IH \\ Departamento de Serviço Social - SER \\ Programa de Pós-Graduação em Política Social - PPGPS
}

TESE DE DOUTORADO

\title{
AS RESPOSTAS DO ESTADO ÀS DEMANDAS SOCIAIS E ÉTNICO-RACIAIS: PARTICULARIDADES NO BRASIL ENTRE 2003 E 2013
}

Carlos Alberto Santos de Paulo

Brasília, agosto de 2015 
Carlos Alberto Santos de Paulo

AS RESPOSTAS DO ESTADO ÀS DEMANDAS SOCIAIS E ÉTNICO-

RACIAIS: PARTICULARIDADES NO BRASIL ENTRE 2003 E 2013

Tese de Doutorado apresentada o Programa de Pós - Graduação em Política Social do Departamento de Serviço Social da Universidade de Brasília/UnB, como requisito parcial à obtenção do Título de Doutor em Política Social.

Aprovada em , de de 2015

BANCA EXAMINADORA

Prof. ${ }^{\text {a }} \mathrm{Dr}^{\mathrm{a}}$ Ivanete Salete Boschetti (Orientadora - SER/UnB)

Prof. Dr. Mário Lisboa Theodoro (Co-Orientador - SOL/UnB)

Prof ${ }^{\underline{a}}$ Dr $^{\mathrm{a}}$ Rosa Helena Stein (SER/UnB)

Prof ${ }^{-a}$ Dr $^{\text {a }}$ Silvia Cristina Yannoulas (SER/UnB)

Prof $^{\mathrm{a}}$ Dr $^{\mathrm{a}}$ Christiane Girard (SOL/UnB)

Prof. Dr. Evilásio Salvador (Suplente - SER/UnB) 
AGRADECIMENTOS

Inicialmente, agradeço à força da ancestralidade e à presença de Xangô em minha existência, sem a qual não teria a resistência para me manter com alguma sanidade para lidar com o racismo diário há mais de meio século. Sou um sobrevivente, desejando contar uma história de um outro jeito.

À minha orientadora, Prof ${ }^{a} \mathrm{Dr}^{\mathrm{a}}$ Ivanete Boschetti, pela aceitação em assumir a orientação já no final desse atropelado momento de conclusão da tese e pelos diálogos intermináveis e ponderações firmes quanto aos caminhos da pesquisa.

A meu co-orientador, Dr. Mário Lisboa Theodoro, pela cumplicidade das lutas que travamos e ainda temos que travar, publicamente quero expressar meu mais profundo reconhecimento pelo respeito e compromisso com esse seu irmão mais novo.

Às professoras doutoras Christiane Girard, Rosa Helena Stein e Silvia Cristina Yannoulas, pela firme determinação em ouvir-me em momento crucial da finalização deste trabalho e sobretudo pelas considerações feitas no sentido de qualificar o esforço de um velho militante para quem as dores da luta já se apresentam como um fardo. Não foi possível capitular pela forma como a banca se mostrou confiante de que apesar dos percalços eu poderia dizer algo para a academia. Parodiando o título do livro do Pablo Neruda, Confesso que Vivi.

À grande rede de amigos e militantes que se posicionaram para apoiar e incentivar e debater muitas das minhas empíricas percepções em torno do tema; ao Prof. Dr. Ivo Pereira de Queiroz, presidente do Sindicato dos Professores do Instituto Tecnológico do Paraná; a Antônio Teixeira, "gente do bem" e coordenador de pesquisa da Igualdade Racial do IPEA; aos estudantes de Serviço Social da Universidade Católica de Brasília; a meus irmãos e irmãs de santo que alimentaram minha conexão com meu orixá, quando estive ausente fisicamente, em especial, a Meu Babalorixá, Prof. Msc Reginaldo Daniel Flores, e a meus irmãos, Prof. Dr. Edmilson Meneses dos Santos (Baba Egbé) e Prof. Dr. Luís Eduardo Almeida (Afikodé). Motumbá! 
Insiro aqui uma pessoa em particular, que merece especial deferência, por insistir ferrenhamente na conclusão desse trabalho, um "branco testado", Prof. Msc. Lunde Braghini, pela revisão e diálogos profundos sobre a questão racial, mais que um processo de revisão, exercitamos uma forma de ver o Brasil um país sem racismo. Muito obrigado.

E finalmente à vida, por me colocar diante de tantos desafios e ao mesmo tempo me possibilitar ver o tempo tecendo molduras de esperanças quer na recuperação de Veronica Maria da Silva Gomes, após um tenebroso inverno, quer no sorriso de Malik (meu neto), bafejo de esperança e sentido de luta contra todas as formas de discriminação e nas divertidas e por vezes tristes batalhas de uma grande família negra para sobreviver nesse país denominado de Brasil.

Às vezes me perguntam: - Está cansado de tanta luta? Respondo: Ainda não, preciso viver... Como diz Wally Salomão, "a felicidade do negro é uma felicidade guerreira". 


\author{
Universidade de Brasília - UnB \\ Instituto de Ciências Humanas - IH \\ Departamento de Serviço Social - SER
}

AS RESPOSTAS DO ESTADO ÀS DEMANDAS SOCIAIS E ÉTNICORACIAIS: PARTICULARIDADES DO BRASIL ENTRE 2003 E 2013

Tese de Doutorado
apresentada ao Programa de
Pós-Graduação em Política
Social do Departamento de
Serviço Social da Universidade
de Brasília/UNB, como requisito
parcial à obtenção do Título de
Doutor em Política Social.

Orientadora: $\operatorname{Prof}^{\mathrm{a}} \quad \mathrm{Dr}^{\mathrm{a}}$ Ivanete Salete Boschetti 
Carlos Alberto Santos de Paulo

Brasília, Agosto de 2015 


\section{RESUMO}

A presente tese de doutorado tem como ponto de partida a análise do caráter complementar da dominação europeia e da estruturação das bases do capitalismo na formação da nação brasileira. Procurou-se mostrar como o longo período de escravidão deitou a base histórica para a explicação dos sistemas de relações sociais brasileira, cuja estruturação, atualização e manutenção remonta aos 297 anos do período da experiência escravista colonial (1535 a 1822), aos 66 anos da experiência nacional escravocrata (1822 a 1888), e aos 126 anos da experiência republicana (1889 a 2015).

Nesse processo histórico as relações étnico-raciais tiveram papel marcante na configuração de uma nação aos moldes europeus e a herança escravocrata veio a se tornar um empecilho às pretensões de uma sociedade igualitária. Procuramos evidenciar as estratégias de naturalização da história brasileira a partir da fragmentação e colonização do saber científico ora nega, ora invisibiliza, ora diminui, ora distorce o papel do processo escravista como um momento formativo de nossa história presente.

As diversas estratégias constituídas para negar a presença negra terminaram por adiar a solução de uma questão que ficou em aberto e que hoje se configura em uma dimensão maior, inalcançável pelo tratamento meramente pontual da reinserção da população negra através de referenciais residuais de políticas simbólicas.

O fulcro do trabalho é a compreensão do período recente de elaboração de políticas públicas voltadas para a população negra, principalmente após a Constituição de 1988. Neste curto período da vida republicana, visualizamos pelo menos três níveis de políticas raciais no Brasil - culturalista, legalista e desenvolvimentista -, com as quais o estado brasileiro tentou responder às demandas do movimento negro, mas sem rompimento revolucionário com a matriz eurocêntrica.

Palavras-chave: Escravidão; Racismo; Políticas Sociais. 


\begin{abstract}
This doctoral thesis has as its starting point the analysis of the complementary nature of European domination and structuring foundations of capitalism in the consolidation of the Brazilian nation. The attempt was to show how the long period of slavery laid the historical basis for the explanation of Brazilian social relations systems in which its structuring, updating and maintenance dates back 297 years from the period of colonial slave experience (1535-1822), to 66 years of the slave national experience (1822-1888), and the 126 years of the Republican experience (1889-2015).

In this historical process, the racial relations had a strong role in shaping the nation to European molds and the slave heritage was to become a hindrance to the claims of an egalitarian society. It was the intent here to highlight the naturalization strategies of Brazilian history from the fragmentation and colonization of scientific knowledge that denies, turns invisible, sometimes decreases and other times distorts the role of the slavery process as a formative moment in our present history.

The several strategies made to deny the black presence ended up postponing the solution of a question that remains unanswered and which is now set on a larger scale, unreachable by the occasional treatment of the reintegration of the black population through residual references of symbolic policies.

The core of the work is the understanding of the recent period of elaboration of public policies for the black population, mainly after the 1988 Constitution In this short period of republican life. It is noticeable at least three levels of racial policies in Brazil - culturalist, legalistic, developmental - in which the Brazilian state tried to respond to the demands of the black movement, but without any trace of a revolutionary break with the Eurocentric matrix.
\end{abstract}

Key-words: Slavery, Racism, Social policies. 
O mito fundante é uma história que localiza a origem da nação, as pessoas e suas características nacionais como tão antigas que elas estão perdidas na névoa do tempo, não "real", mas mítico.

Eric Hobsbawm 
INTRODUÇÃO

CONSIDERAÇÕES METODOLÓGICAS 20

CAPÍTULO 1 - CAPITALISMO E ESCRAVIDÃO NA HISTÓRIA DO BRASIL 31 MATRIZ COLONIAL .33

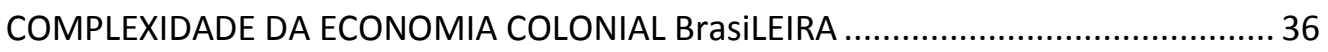

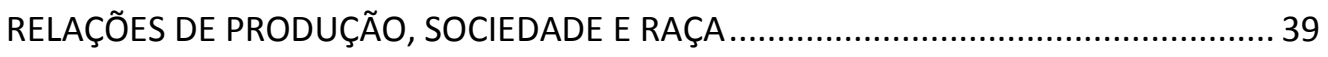

INTEGRAR IGUALITARIAMENTE OU INCORPORAR HIERARQUICAMENTE? ................. 41

CAPÍTULO 2 - MENTALIDADE RACIAL E HEGEMONIA NA CONSTRUÇÃO DA SOCIEDADE BRASILEIRA

ABOLIÇÃO: SIGNIFICADOS DE UM MARCO SOCIAL................................................... 46

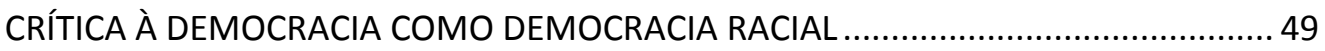

AUSÊNCIA DO MERCADO DE TRABALHO, “CULTURA DO FAVOR” E FRAGILIDADES DA SOCIEDADE CIVIL 52 CONSTITUIÇÃO DE 1824, ABOLICIONISMO E INCORPORAÇÃO NEGRA À NAÇÃO ..... 55 IDEOLOGIA DO BRANQUEAMENTO E RESISTÊNCIA A INTEGRAR .............................60 DAS CONSTITUIÇÕES APÓS-ABOLIÇÃO À FRESTA DA CONSTITUIÇÃO DE 1988...........66 CICLOS CONSTITUCIONAIS E INTEGRAÇÃO DA POPULAÇÃO NEGRA 69 CAPÍTULO 3 - PERIODIZAÇÃO DAS POLÍTICAS RACIAIS NO BRASIL CONTEMPORÂNEO.

POLÍTICA CULTURALISTA - ANOS 1980 .71

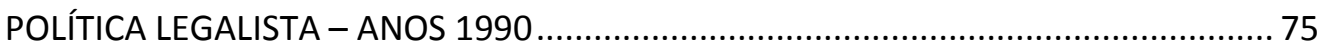

Tipologia das Organizações do Movimento Negro ................................................ 76

Do I ENEN à Marcha Zumbi dos Palmares - rumo a reivindicações estruturais .... 78

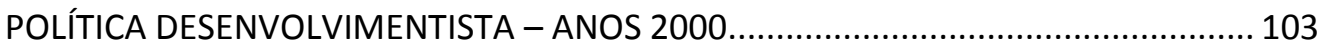

O desenvolvimento nacional como utopia burguesa ......................................... 110

O neodesenvolvimentismo como simulacro do desenvolvimento......................... 113 
CAPÍTULO 4 - A POLÍTICA DE PROMOÇÃO DA IGUALDADE RACIAL

A criação da Seppir 117

PLANO NACIONAL E CONFERÊNCIAS. 120

OS DESAFIOS PARA A INSERÇÃO DA POLÍTICA DE PROMOÇÃO DA IGUALDADE RACIAL 125

LIMITAÇÕES DO NEODESENVOLVIMENTISMO. 131

CENSO E CONTRA-SENSO NAS POLÍTICAS RACIAIS 136

AS ASSIMETRIAS RACIAIS DE 1995 A 2013 139

CONCLUSÃO

REFERÊNCIAS

\section{LISTA DE SIGLAS}

APNS - Agente de Pastorais Negros

CENARAB - Centro Nacional de Articulações das Religiões Afro Brasileira

CEAP - Centro de Articulações de Populações Marginalizadas CEERT - Centro de Estudos das Relações do Trabalho e Desigualdades CAGED - Cadastro Geral de Empregados e Desempregados CUT - Central Única dos Trabalhadores CGT - Central Geral de Trabalhadores CNPIR - Conselho Nacional de Políticas de Promoção da Igualdade Racial

CONAPIR - Conferência Nacional de Promoção da Igualdade Racial DIEESE - Departamento Intersindical de Estatísticas e Estudos Socioeconômicos

ENEN - Encontro Nacional de Entidades Negras FAT - Fundo de Amparo ao Trabalhador FIPIR - Fórum Intergovernamental de Promoção da Igualdade Racial FCP - Fundação Cultural Palmares GRUCON - Grupo de União e Consciência Negra 
GTI - Grupo de Trabalho Interministerial

GTDEO - Grupo de Trabalho de Emprego e Ocupação

IPEA - Instituto de Pesquisa e Estatísticas Aplicadas

IBGE - Instituto Brasileiro de Geografia e Estatísticas

ISER - Instituto de Estudos da Religião

IPCN - Instituto de Pesquisa da Cultura Negra

$\mathrm{MN}$ - Movimento Negro

MNUCDR - Movimento Negro Unificado contra Discriminação Racial

OIT - Organização Internacional do Trabalho

PT - Partido dos Trabalhadores

PSDB - Partido Social da Democracia Brasileira

PCdoB - Partido Comunista do Brasil

PLANAPIR - Plano Nacional de Promoção da Igualdade Racial

PNDH - Plano Nacional de Direitos Humanos

ONU - Organização das Nações Unidas

RAIS - Relação Anual de Informações Sociais

SEADE - Fundação Sistema Estadual de Análise de Dados

SEPPIR - Secretaria Especial de Políticas de Promoção da Igualdade

Racial

UNEGRO - União dos Negros pela Igualdade

\section{LISTA DE FIGURAS}

FIGURA 1 - Níveis das Políticas Raciais no Brasil

\section{LISTA DE QUADROS}

QUADRO 1 - Rendimento Médio Mensal

QUADRO 2 - Rendimento Médio Domiciliar

QUADRO 3 - Distribuição Percentual da População Ocupada com 16 anos ou mais de idade

QUADRO 4 - Taxa de Desocupação da População de 16 anos ou mais de idade 
QUADRO 5 - Rendimento Médio Mensal no Trabalho Principal da População Ocupada de 16 Anos ou mais de idade QUADRO 6 - Distribuição Percentual da População Ocupada de 16 anos ou mais de idade

QUADRO 7 - Proporção de Pessoas de 25 anos ou mais de idade com menos de 1 ano de Estudo QUADRO 8 - Taxa de Escolarização Líquida QUADRO 9 - Cobertura Direta ou Indireta da Previdência Pública na População em Idade Ativa QUADRO 10 - Proporção de Domicílios Particulares com Esgotamento Sanitário Adequado 


\section{INTRODUÇÃO}

O processo de transição democrática observado no século $X X$ propiciou um cenário bastante dinâmico no que concerne a novas configurações do Estado brasileiro. A pauta democratizante observada nesse período, sobretudo no final da década de 1980 e início dos anos 1990, possibilitou uma estreita relação entre Estado e sociedade.

As mudanças observadas no período em questão, pautadas por uma ampla reforma liberal do Estado, culminaram no restabelecimento de um cenário favorável à ampliação das desigualdades, cujos impactos, por um lado, fortaleceram a sociedade de mercado $e$, por outro, impulsionaram a mobilização dos atores sociais na ampliação de defesa dos direitos sociais, bem como o fomento da representação política de diversos setores da sociedade.

Essa conjuntura sinalizava uma efetiva mudança de rumos por parte dos movimentos sociais, redefinindo um projeto político em que a luta de classes, aliada à luta pelas identidades, terminaria por colocar em xeque a própria configuração política do Estado.

As novas demandas sociais, alicerçadas pelos princípios éticos, políticos e culturais, promoveram a reformulação de uma agenda ampliada, para governos e sociedade, em torno das questões sociais emergentes em meio ao contexto neoliberal e às crises vivenciadas no período.

Os avanços ocorridos nesse contexto, decorrentes da mobilização e da participação social, asseveram a necessidade de reflexões em torno das políticas sociais articuladas de maneira indissociável aos níveis políticos, culturais, econômicos e jurídico-formais, entrando em choque com o modelo de política historicamente marcado por uma forte tradição capitalista de acumulação e distribuição das riquezas.

A rediscussão do papel do Estado e da centralidade da questão nacional frente às diversas culturas e segmentos étnicos sedimentaram um forte debate sobre as noções de cidadania, sobre a atuação desses agentes sociais, bem como sobre as novas formas de articulação e mediação das ações políticas no fortalecimento da participação do conjunto da sociedade. 
A mudança observada nesse contexto caracteriza-se por extensos e intensos debates com o objetivo de conciliar as expectativas macroeconômicas de estabilidade financeira e as metas de reformas sociais voltadas para a melhoria de eficácia e efetividade das políticas sociais.

De acordo com Anete Ivo,

[...] essas políticas são também mediações historicamente instituídas, que buscam resolver as contradições entre a apropriação e distribuição da riqueza, num contexto hoje marcado pelo dilema de uma integração num regime de acumulação capitalista globalizado que produz efeitos sobre a cidadania, que, ao mesmo tempo, procura restaurar a democracia na América Latina. (IVO, 2006, p. 62).

A Constituição Federal Brasileira de 1988 (CF/1988) redimensiona o marco da atuação governamental no âmbito social. Observa-se uma nova postura do Estado face a questões importantes, elegendo prioridades que culminaram por dotar o país, finalmente, de uma estrutura de proteção social.

Os princípios emanados dessa Constituição trataram de dar eficácia aos direitos e garantias fundamentais, consubstanciados nos direitos sociais, desvinculando esses direitos do modelo econômico, efetivando um modelo securitário de política pública independente da lógica de mercado.

A sociedade brasileira convive com uma desigualdade de notório viés racial. A população negra é a que está mais afeta à situação de pobreza e de miséria e aos percalços sociais daí decorrentes: desemprego, informalidade, piores condições habitacionais e de infraestrutura, de acesso à educação e à saúde, dentre outros.

O modelo de sociedade erigido no Brasil, do ponto de vista dos direitos, revela uma emblemática omissão histórica quanto às escolhas políticas de tratamento na integração do negro na sociedade em questão, no que tange ao mercado de trabalho e, efetivamente, às condições infraestruturais de uma sociedade de classes.

Foram 353 anos de um modelo econômico com base na escravidão (1535-1888), que teve como sustentação o racismo estruturante das relações sociais brasileiras, e que resultou em um quadro de desigualdades abissais para alguns segmentos populacionais, com ênfase para a população negra, como atestam as fontes dos órgãos oficiais brasileiros. 
A percepção de que o enfrentamento da desigualdade passa pela adoção de políticas direcionadas ao campo racial ainda é algo a ser construído. De fato, a naturalização da desigualdade em nosso país está, em grande medida, associada à existência do racismo e de seus desdobramentos: o preconceito e a discriminação racial.

O governo brasileiro no pós-constituinte (1988) iniciou um processo lento e ainda tímido de construção de uma área de atuação denominada promoção da igualdade racial. Este parece ser o grande desafio, cujo efetivo enfrentamento poderá representar um salto qualitativo na consecução de uma sociedade mais igual e democrática.

Urge analisar se os mecanismos adotados pelo governo brasileiro, com base nas formulações e escolhas políticas das ações de enfrentamento da pobreza e suas variantes raciais e de classe, possibilitam uma maior justiça social e equidade no acesso aos direitos sociais dos negros no país.

Para uma investigação inicial, a questão central que se apresenta é: de que forma o Estado brasileiro vem lidando com a questão racial? Isso considerando que no cenário atual a urgência da inclusão desta temática coloca-se como essencial para o alargamento da democracia para além das formalidades institucionais.

Por outro lado, não se pode negar as contradições inerentes ao atual processo de inserção dos negros e ao papel das organizações negras na conformação dessa noção de Estado.

As indagações que esse estudo nos sugere são para o entendimento de como romper com o círculo vicioso de pensar uma sociedade democrática sem levar em conta as escolhas pretéritas do capitalismo pós-colonial, cujas bases têm sido reproduzidas sobretudo a partir dos silêncios intencionalmente construídos no sentido de omitir os efeitos desastrosos da escravidão.

O processo de transição observado do escravismo para o capitalismo coincidiu com um momento significativo na reestruturação do modelo econômico e suas relações assimétricas. A política nacional sofreu tensões e 
conflitos internos e externos e essas influências configuram a gênese do país em seu pretendido anseio de nação autônoma.

A proposta desta tese é possibilitar a reflexão sobre esse processo, além de superar a percepção da escravidão como uma fotografia - um evento interrompido, descontinuado no presente - plasmada no tempo, sendo, para tanto, fundamental recuperar o filme - o processo de contínuos desdobramentos - com suas diversas nuances e movimentos.

Para compreender a política social em vigor no país, observando as manifestações que ensejam as decisões por esse ou aquele modelo, torna-se essencial mensurar e buscar perceber a intencionalidade contida na formulação e na escolha. Como assevera Pereira (2008),

[...] já ficou clara a perspectiva pela qual a política social será aqui considerada. Trata-se daquela que apreende essa política como produto da relação dialeticamente contraditória entre estrutura e história e, portanto, de relações - simultaneamente antagônicas e recíprocas - entre capital $x$ trabalho, estado $x$ sociedade e princípios da liberdade e da igualdade que regem os direitos de cidadania. Sendo assim, a política social se apresenta como um conceito complexo que não condiz com a ideia pragmática de mera provisão ou alocação de decisões tomadas pelo Estado e aplicadas verticalmente na sociedade (como entendem as teorias funcionalistas). (PEREIRA, 2008, p. 166).

Propõe-se, assim, um exame crítico à luz das conceituações em torno da Política Social, da Cidadania, dos Direitos, do Estado e da Democracia, como elementos de análise e proposição para as crescentes questões em torno das mazelas raciais que perpassam a realidade brasileira.

A complexidade e a abrangência desse tema fazem com que a sua análise seja cada vez mais relevante, fonte de pesquisa e debate. A compreensão dessas questões não tem ocupado um lugar pertinente que favoreça descrever e analisar seus efeitos devastadores na inibição da democracia em decorrência do racismo.

Na prática, os vários projetos de sociedade não podem continuar a ser vistos como fenômenos homogêneos e uniformes. Ao contrário, é preciso buscar compreender a sua hibridez e antagonismos, próprios de realidades com distintas naturezas e procedências, que se apresentam de forma complexa e heterogênea dentro do contexto social brasileiro. 
A peculiaridade de que se revestem as formulações políticas de igualdade e desigualdades carece de mensuração quanto aos avanços dos preceitos legais, mas, sobretudo, de cotejar os cenários e contextos históricos da luta política dos movimentos sociais que ensejaram mudanças. Importa saber como desvendar o nebuloso cenário que encobre as relações sociais contemporâneas, marcadas pelo desenvolvimento do capitalismo.

Para tanto, faz-se necessário "garimpar", no movimento da história, as contradições inerentes ao processo histórico do capitalismo nacional. Utilizando as categorias do materialismo histórico-dialético, propondo uma análise para além das compreensões da economia política tradicional, é preciso refletir sobre a produção material escravocrata para compreender as complexas determinações dos indivíduos envolvidos nesse contexto.

Dentre os aspectos propostos pela tese, pretende-se descrever como as relações sociais capitalistas moldaram a realidade social brasileira, tornando opacos os efeitos da escravidão descolada da relação capital-trabalho, ocultando as contradições decorrentes dessa transição entre trabalho escravo e trabalho livre.

Uma perspectiva possível para o trabalho de análise da evolução da questão racial no Brasil depende de uma fundamentação histórica que contemple as diversas fases do desenvolvimento nacional, marcadas inicialmente pela ordem escravista, passando pelas pressões externas de modernização da mão de obra estrangeira através da subvenção do Estado à imigração europeia, conformando-se em um processo de industrialização em que a integração econômica e social da população negra tornou-se descartável.

Buscar-se-á, no âmbito da pesquisa aqui proposta, sair de um contexto no qual as análises relativas à questão da pobreza restringem-se à minimização dos efeitos excludentes da lógica do capitalismo e suas consequências estritamente materiais, determinando o caráter compensatório com que se revestem essas políticas, terminando por suprimir a reação dos "pobres" atentos a uma sinalização de carisma neoliberal, transformando os avanços preconizados por essas conquistas sociais de direitos em concessões.

Conforme assevera Ivo, "nessas circunstâncias, a 'retórica da pobreza' constituir-se-ia mecanismo de 'consentimento ampliado' que atende à agenda 
neoliberal, traduzindo-se em ações técnicas focalizadas, de caráter gerencialista, comunitária e mitigadora da pobreza." (IVO, 2006, p. 62).

A formulação e a implementação de políticas sociais com essa configuração remetem a avaliar o grau de pertinência e impacto de ações simbólicas e pontuais da natureza dessas políticas.

Enquanto se minimizam as responsabilidades efetivas dos Estados e governos no enfrentamento dos desafios para a promoção de mudanças no regime político democrático, que impõem uma efetiva ampliação da questão social com viés racial, há, ao mesmo tempo, o diálogo com a história de negação e exclusão do segmento em pauta.

A conjuntura crítica com que nos deparamos hoje impele-nos a uma profunda avaliação quanto a esses desafios propostos, relativos à percepção do racismo enquanto obstáculo à consolidação dos direitos sociais.

É preciso salientar que o fim da escravidão no país perpetua o modelo excludente da estrutura étnica, com forte referência eurocêntrica. Além de que o atraso histórico da abolição e os mecanismos de alforria garantiram aos "senhores de escravos" a ampliação de suas riquezas à custa do dinheiro público.

Por fim, e de forma bastante relevante, os ideais do igualitarismo enquanto ficção sociocultural promoveram, até os dias atuais, dificuldades quase intransponíveis na revisão de princípios formais/legais, em dissonância com as especificidades substantivas de cada segmento social.

Na formulação e condução de estudos que realizamos para a obtenção do mestrado nós nos propusemos à análise sobre Movimento Negro, Participação e Institucionalidade: desafios para uma agenda pública. Naquela ocasião, foi possível avaliar o grau de incorporação ${ }^{1}$ das ações propostas pelo Movimento Negro Brasileiro a uma agenda pública no Brasil. Decorridos oito anos, esses estudos, são retomados, ampliando e redimensionando o escopo da pesquisa.

${ }^{1}$ Aqui destacamos a distinção necessária entre incorporação e integração. Partimos da premissa de que, ao se "incorporar", não se está de fato efetivando uma recepção às demandas de determinado grupo social, mas apenas inserindo pequenas concessões no sentido de minimizar as reivindicações. Quanto à dimensão da integração, sobretudo de políticas, é fundamental que ação de "integrar" se dê em um nível igualitarista, no qual as demandas sejam efetivadas com base na negociação e em consensos capazes de configurar mudanças substanciais para os grupos envolvidos. 
As principais conclusões observadas a época levaram à confirmação da hipótese de que havia um hiato entre as demandas propostas pelo movimento negro e as pífias respostas governamentais, sem articulação necessária entre as ações ministeriais para impactar nas políticas raciais.

No atual momento, do doutorado, importa saber de que forma a governabilidade no Brasil tem enfrentado a questão do racismo e seus dilemas quanto às garantias sociais constitucionais de igualdade formal, cujos efeitos, ao mesmo tempo em que sinalizam na direção de ampliação dos direitos civis e políticos, também revelam as desigualdades no acesso à distribuição das riquezas e aos direitos sociais básicos e a obsolescência do modelo capitalista.

\section{CONSIDERAÇÕES METODOLÓGICAS}

Ao se analisar o modelo da formação social brasileira, observa-se a existência de mecanismos institucionais sutis, persistentes, que criam óbices à fruição de políticas de integração que procurem corrigir as distorções de um passado de segregação e alijamento da população negra.

Sob a alegação de uma efetiva crença na neutralidade jurídica, os primórdios do pensamento jurídico brasileiro foram estruturados com base em regras de funcionamento que tomaram como ponto de partida as formulações encontradas pelos juristas e intelectuais da época para o trato com as questões de ordem social, negando radicalmente o componente racial.

A relação intrínseca entre o modelo eugênico pretendido ${ }^{2}$ e os ideais nacionalistas com base na cultura europeia estruturou a sociedade brasileira e estabeleceu as diretrizes para a consolidação de uma elite dominada pelo nascimento, pertencimento étnico-racial, nível hierárquico, sexo e riqueza material.

\footnotetext{
2 Nas primeiras décadas do século $X X$, houve a difusão da uma série de ideias acerca do que se chamou de "Eugenia". Criada no século XIX por Francis Galton, a eugenia visava ao aprimoramento da raça humana pela seleção dos genitores, tendo como base o estudo da hereditariedade. No Brasil, a eugenia é foi introduzida em 1914 na Faculdade de Medicina do Rio de Janeiro com a tese de Alexandre Tepedino. O 1을 Congresso Brasileiro de Eugenia, em 1929, objetivava a adoção de políticas governamentais de "higiene radical" e "políticas estatais colonizatórias e imigratórias". Preconizava-se uma nação homogênea e a criação de um "tipo racial" brasileiro "eugenicamente" mais "branco".
} 
Por outro lado, a arqueologia do modelo civilizatório inaugurado aqui também se pautou pela lógica de uma nação híbrida, na qual os ideais revolucionários da igualdade formal de cariz francês se adequariam aos moldes universalistas de uma nação democrática, racialmente falando, e com características peculiares distintas de qualquer expressão existente nos países colonizadores.

É como se os determinantes culturais transplantados pela língua, religião e imaginário estivessem dissociados das determinações políticas e econômicas de poder.

Nesse sentido, é fundamental trazer ao bojo das discussões o papel político fundamental que sedimentou a ideia de democracia racial, conjugada em paralelo com uma forte propaganda imigracionista para os trabalhadores desempregados da Europa Ocidental no início do século XX.

Esse estratégico movimento dual verificado pelas ações do Estado brasileiro, enfunado pelos ventos modernizantes colonizadores, em nosso entendimento, marca os ideais de formação das identidades nacionais preconizados pelo domínio político das elites e governos do período.

Essas considerações iniciais devem-se ao fato de que, ao tratarmos da difícil questão das relações raciais no Brasil e das demandas preconizadas pela relação entre Estado e sociedade e seus determinantes sociais, não se pode omitir ou negar as variantes históricas para uma compreensão mais realista das relações socioeconômicas e políticas através da escravidão, combatendo o determinismo vigente até os dias atuais.

O Estado moderno brasileiro, forjado às nascentes idealizações das revoluções burguesas, foi constituído em torno de um ideário liberal, com soberania popular assegurada por regime político representativo, separação dos poderes, supremacia das leis com sujeição do Estado, legalidade e igualdade reconhecida no plano formal.

Nesse sentido, sua concepção enquanto lócus de poder esteve assentada nas liberdades públicas, asseverando os valores individualistas que, a rigor, colocavam limites à democracia e, ao mesmo tempo, consagravam uma ordem institucional abertamente excludente.

É no contexto dessas transformações que se depreende o desafio teórico de buscar, nas raízes históricas do capitalismo industrial e de suas 
injunções do processo histórico, os fundamentos para a persistente negação de uma questão racial determinante.

Isso deve explicar, ou ao menos sinalizar pistas, sobre como os arranjos institucionais e o modelo de gestão atual refletem, em grande parte, a ambiguidade com que a temática racial tem sido tratada, e tudo isso pode indicar os limites nos quais o debate e as ações de integração de uma política racial estão circunscritos.

Para tanto, o objeto central desta pesquisa é o conjunto de respostas do Estado brasileiro às demandas sociais e étnico-raciais forjadas com base nessa orientação cultural dominante, configurada ao longo do período colonial até os dias atuais, na qual prevaleceu uma negação das diferenças raciais e, paradoxalmente, um sentimento idealizado de uma nação miscigenada sem conflitos.

Nesta pesquisa, interessa compreender a persistência das hierarquias dos grupos sociais e os reflexos disso na atualidade ao se propor a integração de políticas públicas com recorte racial.

Nesse contexto, as questões fundadas em exigências técnicoadministrativas promocionais de uma igualdade pretendida, ao entendimento, são fortemente influenciadas pelo caldo da cultura política que nega a existência de barreiras ideológicas para a consolidação de uma efetiva democracia racial. Dessa forma, elencamos alguns pontos importantes para sedimentar a análise:

$\checkmark$ O Estado brasileiro se constituiu a partir de um princípio igualitarista, regulado pela manutenção da desigualdade racial.

$\checkmark$ O ideário de identidade nacional parece ter submetido especificidades raciais a princípios gerais baseados na classe dominante e branca.

$\checkmark$ As determinações econômicas, políticas e sociais sustentadas pelas teorias racistas e pelas ideologias burguesas formaram um padrão de democracia que nega as particularidades de uma sociedade multirracial e suas tensões ideológicas.

$\checkmark$ Por fim, infere-se o papel decisivo dos grupos hegemônicos, em engendrando um projeto a longo prazo de modernização, cujos valores 
importados da Europa forneceram a base estruturante do modelo mental e institucional da ordem social marcadamente branca.

Com isso, pretende-se inferir que, a despeito dos avanços institucionais no trato com a questão racial, hoje é fundamental pensar o contexto histórico em que se deram as transformações da estrutura econômica, em que o capital industrial nascia do capital agrícola, em processo que gerava contexto de "irresoluções" quanto à presença negra para a nascente economia capitalista.

A base dessa trajetória analítica segue o curso da história do Brasil, a partir dos escombros do antigo modo de produção baseado na escravidão, para sugerir que os aspectos ideológicos que formataram "um não lugar" nas sociedades de classe para o elemento negro persistem até os dias atuais.

Neste sentido, parte-se do pressuposto de que as representações sociais e culturais atribuídas ao negro naquele período terminaram por sedimentar uma ideologia, na acepção de Marx, que tratava de mascarar uma dominação, dando uma forma universal aos interesses particulares de uma classe (MARX, 2010, p.46).

Dessa forma, as relações atualizadas parecem seguir essa mesma fórmula, ao buscar na universalidade a representação compartilhada de uma sociedade de classes destituída de peculiaridades raciais, de gênero, dentre outras.

O pensamento ideológico predominante no período em questão atendia ao pensamento dominante, forjando uma ideia de pensamento único, quando, na verdade, representava construções teóricas do grupo dominante formado por proprietários de terras.

A hipótese levantada é de que essas representações pacificadoras de uma realidade social, plasmadas pela incorporação de um modelo econômico novo, balizaram a construção de uma interpretação da história descolada dos fatos concretos do período pós-abolicionista. E que, decorrido longo período desde então, o Estado brasileiro ainda permanece com a mesma percepção desse "não-lugar" do negro e, por conseguinte, as políticas sociais estão também coladas a conformação de uma política residual amenizadora das tensões decorrentes da crise do capitalismo. 
O que vem a ser uma Política de Promoção da Igualdade Racial? Como se produz igualdade quando o processo histórico é negado enquanto obstáculo a essa igualdade? O Estado brasileiro fez uma opção, segundo Holston (2013, p.58):

[...] as elites dominantes imaginaram uma cidadania nacional includentemente desigualitária, fundamentalmente contrária para os franceses e os americanos, pois o tipo de liberalismo que buscavam criar não tinha compromisso com a democracia. Era liberal apenas no sentido de que os direitos individuais dependiam da igualdade formal dos indivíduos perante a lei, sem igualdade ou justiça substantivas. (HOLSTON, 2013, p.58).

Em que medida as políticas de Promoção da Igualdade Racial são efetivamente políticas públicas, com capacidade de alterar a realidade social do negro? A persistência dos indicadores desfavoráveis à população negra vai na direção contrária aos propósitos dessas políticas.

$\checkmark$ Qual o papel das teorias e ideologias raciais relativas à integração do negro na sociedade brasileira a partir do fim da escravidão?

$\checkmark$ Quais os limites encontrados pelo governo em integrar as políticas sociais de cariz racial na reformulação do papel do Estado?

$\checkmark$ Quais os mecanismos adotados que incorporam as ações de políticas de promoção da igualdade racial?

Busca-se, então, compreender de que forma as políticas sociais brasileiras incorporaram e/ou integraram demandas sociais na consolidação de direitos com recorte étnico-racial, com identificação de sua efetivação a partir dos aportes orçamentários e sua incidência nos gastos sociais.

Esse objetivo geral será desdobrado nos seguintes objetivos específicos:

$\checkmark$ Analisar os antecedentes históricos que propugnam a estruturação de um modelo de integração social do negro na sociedade de classes;

$\checkmark$ Identificar políticas de caráter racialista que objetivaram atender às características e peculiaridades raciais existentes no país; 
Verificar como as demandas da população negra foram integradas nas políticas sociais de enfrentamento ao racismo a partir das ações e programas governamentais das políticas de promoção da igualdade racial nos últimos anos.

A pesquisa aponta para procedimentos metodológicos capazes de contribuir para a revelação dos fatores ideológicos ligados à minimização do papel central da escravidão nas configurações estruturais do mundo do trabalho na sociedade brasileira e suas implicações nos processos sociais.

O objetivo não é apresentar mais uma interpretação da realidade social do negro, mas sim enfatizar e refutar alguns aspectos sócio-históricos que colaboram para uma abordagem, por vezes acrítica, reveladora de um silenciamento quanto ao papel central da questão racial na construção da sociedade brasileira. Pretende-se buscar o entendimento da função ideológica do racismo na perpetuação e manutenção da ordem hierárquica com que se mantêm inalterados os referenciais de análise da questão racial, apesar das políticas afirmativas adotadas recentemente.

O interesse na temática e no desenvolvimento da pesquisa decorre de inquietações quanto a compreensões, por ângulos e perspectivas diferentes, que permitam identificar as tensões existentes entre integração e incorporação da questão racial como um elemento que estrutura o modelo de democracia e funcionamento em nossa sociedade.

A hipótese inicial é a de que os reflexos desses arranjos originários incidem significativamente nas formulações atuais de políticas raciais, que revelam limites quanto ao seu alcance no atendimento de equalização de oportunidades e de superação do mito da democracia racial.

A revisão do arcabouço da história social, política e econômica exige uma tomada de decisão quanto a escolha do método a ser utilizado, uma vez que o caminho a ser trilhado determinará a profundidade de captação do real.

Esse processo não se dá por pura justaposição de fatos, mas requer a capacidade crítica de tecer o fio da história, observando suas tramas e enredos em uma tessitura capaz de desvelar, a partir dos escombros do período colonial, as abstrações (elaboração do pensamento, reflexões e teorias) que 
sustentaram as raízes perenes de perpetuação das desigualdades e do racismo.

Essa análise convoca diversos aspectos da historiografia para a compreensão de totalidade do processo da formação social brasileira, sem se ater apenas ao modelo de produção (econômico).

Isso requer pensar a escravidão como epicentro da acumulação primitiva na colônia, que mais tarde veio a subsidiar o desenvolvimento do capitalismo nacional. Para lanni (1972), esse é o ponto fundamental para se compreender a sociedade brasileira com seus vieses e contextos peculiares.

Desse modo, ao propor a análise das relações raciais no período em que se deu a transição do escravismo para o capitalismo, as evidências inerentes às tensões do contexto nos levam a adotar um método que seja capaz de apreender o movimento dialético da história, considerando intrinsecamente: o lugar social do negro, antes e depois da abolição; o projeto imigracionista e a política de branqueamento travestida em modernização das forças produtivas e em consonância com os ideais da ideologia burguesa.

Para efeito dessa tese, os esforços vêm no sentido de compreender as leis que fundamentaram o "não-lugar" do negro no interior da sociedade em transição, mas, sobretudo, entender as contradições inerentes à passagem do escravo da condição de mercadoria a indivíduo dotado de liberdade, sem representar com isso uma classe, em uma sociedade estruturada em classes.

Por outro lado, é fundamental depurar de tudo isso as múltiplas determinações que incidirão sobre esse "novo lugar" do negro na reestruturação das relações sociais.

Os determinantes sociais, para lanni (1988, p.112), estabelecem um aspecto dual cujos contornos não são de fácil detecção, pois

O trabalhador livre, em face do antecessor escravizado, é produto de uma verdadeira revolução no modo de produção. Mas é ainda um trabalhador com possibilidades escassas de beneficiar-se do próprio trabalho. O domínio da sociedade continua nas mãos dos proprietários dos meios de produção. A sociedade continua, por isso, seccionada em camadas sociais hierarquicamente distribuídas. Nesse universo, a ideologia dos grupos continua marcada por uma condição básica. Na sociedade de classes em elaboração, a ideologia de classes tem papel decisivo na caracterização e manutenção do novo mundo social. A ideologia dos proprietários dos meios de produção e compradores da força de trabalho será, portanto, marcada por seus interesses fundamentais. 
Por trás da ideologização dos fatores em jogo, é possível a análise desembaraçar as significações determinantes das relações de dominação exercidas pelos brancos sobre os negros (IANNI, 1988, p.112).

Com efeito, esse trabalho investiga contradições e tensões do modelo de sociedade idealizado a partir de um referencial europeu, em que o papel do Estado foi, desde sua instalação, elemento preponderante no sentido de reduzir os efeitos das tensões entre negros e brancos.

A configuração social estruturada contou com uma engenhosa formulação, de lugares sociais definidos pelo pertencimento racial, pela propriedade e pela inserção no mundo do trabalho. Essa configuração é refletida até os dias atuais na perpetuação das desigualdades, sendo essas explicitadas pela segregação racial a qual se revela de maneira inquestionável nos dados estatísticos aqui apresentados.

Neste sentido, ao propor um estudo sobre as relações raciais no Brasil com enfoque no método do materialismo histórico dialético, busca-se apreender a dimensão multifacetada do conflituoso contexto em que se deu a amalgamação da sociedade brasileira em torno de um projeto nacional, hoje refletido em uma integração social inacabada e desigual, mascarada por um princípio de igualdade formal.

De acordo com Masson,

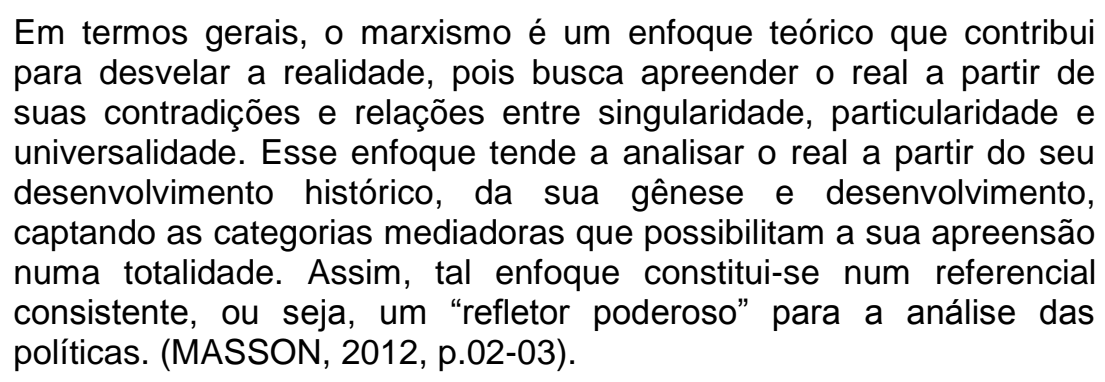

Dessa forma, pretende-se articular cada momento analítico da tese aqui apresentada a fundamentos do materialismo histórico dialético, cuja compreensão síntese seja a de que, no processo histórico sob o qual estamos trilhando essa trajetória, estabelece-se, de início, que as mentalidades hegemônicas do período em destaque sempre afirmaram uma igualdade com 
inspiração nos ideais de uma modernidade que só se fez a partir do olhar europeu.

Pode-se citar, como texto de esclarecimento de tal afirmação, que não pode haver modo de produção capitalista se dois pressupostos não estiverem realizados: o trabalho livre, isto é, uma propriedade do trabalhador que pode ser vendida por ele, e a separação entre o trabalho e a propriedade dos meios de produção. A força de um modo de produção não vem apenas da sua capacidade econômica para repor seus pressupostos, mas também de sua capacidade para incutir, nos membros da formação social, o sentimento da naturalidade desses pressupostos, até que as novas contradições destruam tal sentimento e exibam a violência histórica do sistema.

Desse modo, o caminho metodológico escolhido, o materialismo histórico dialético, permite apreender a realidade social e seus múltiplos sentidos, implicando uma escolha capaz de superar as tradicionais dicotomias entre trabalho escravo e trabalho livre.

Essa escolha traz o reconhecimento de que o referencial teórico para a compreensão dessa realidade estabelece uma exigência epistemológica de não apenas interpretar, mas, sobretudo, transformar a realidade.

Não obstante, neste trabalho, a intenção é relacionar os efeitos da escravidão e seus derivados, como discriminação, preconceito e racismo com a ideologia que permeou a constituição do Estado brasileiro e que vigora até a atualidade, reconhecendo as lutas dos indivíduos envolvidos e suas inflexões como parte essencial do processo constitutivo de uma nova realidade social.

O materialismo histórico dialético estabelece como pressuposto o processo histórico, no qual é possível perceber como os indivíduos se constituem a partir da história, e as derivações que esse novo modelo propugna de superação dos entraves que o modelo escravista impunha ao desenvolvimento das novas forças produtivas.

Há nesse espaço temporal uma conjunção de fatores que atestam ao Brasil uma singularidade quanto à incorporação de uma cidadania baseada na diferença, sob a roupagem de uma pretensa noção de igualdade.

O estudo das relações raciais no Brasil tem sido objeto de muitas pesquisas, no entanto, boa parte dessas investigações parte de uma premissa 
que é o estabelecimento da luta de classe e das injunções desse período quanto a inadaptação do negro à nova ordem social sobretudo do período compreendido entre o fim da escravidão ao industrialismo.

No entanto, segundo Jaccoud (2008, p.45), após a abolição, o debate teórico em torno de uma pretensa inferioridade do negro e as argumentações mais sedimentadas de uma inadequação desse individuo tomará impulso, "naturalizando" as diferenças raciais enquanto constructo hierárquico da nascente sociedade moderna brasileira.

Em verdade, já havia em discussão manifestações expressas de manutenção dessa ordem hierárquica, desde a perspectiva inicial de introdução da escravidão enquanto elo de ligação com a lógica produtiva, o que evidentemente não levou em conta o papel social daqueles que seriam os agentes humanos na consolidação desse modelo.

Ainda nessa linha de argumentação, esse é o ponto central para interpretação dos pilares edificados em torno de um projeto nacional para 0 desenvolvimento.

Dessa forma, é a partir desse momento que se possibilita a construção de um cenário fértil para a construção de ideias fundamentais para as bases racistas preconizadas pelos principais pensadores desse período.

Infere-se que o que estava em jogo, mais que um modelo a ser constituído de organização social, seria a forma de como se poderia adequar a hibridez de um sistema que ao mesmo tempo respondesse as demandas de uma nação moderna e pudesse concomitantemente conviver com a segregação silenciosa de uma escravidão inacabada.

Daí se depreende o eixo pelo qual se estruturou essa tese, ao estabelecer uma linha temporal entre as primeiras investidas colonialistas, passando pelo período imperial e a consolidação da república.

Adotamos a observação da questão racial dentro de uma ótica histórica estruturalista, que permitisse acompanhar a evolução desse período, levando em conta os ajustes para o ingresso do capitalismo de mercado e a superação da tradição agrícola com base na monocultura.

Importou-nos cotejar estudos de autores cujas percepções mais críticas em relação ao tema trouxeram contribuições mais críticas para além do enfoque simbólico e cultural da realidade brasileira. Interessou-nos reafirmar o 
papel central da questão racial, perpassando os debates em torno da mobilidade das condições de vida e da estratificação social, incidindo em modelos de políticas sociais e econômicas por vezes contraditórias.

Com especial atenção, procuramos traduzir os anseios governamentais com e a partir das manifestas intenções, do período imperial ao nascimento da república, quando se efetivam as primeiras constituições com forte teor racista, em cujos conteúdos pode se delimitar o racismo estrutural de origem.

Nesse percurso, enfatizamos o papel central do Estado brasileiro nas conformações dos impasses atuais quanto ao enfrentamento do racismo, do posicionamento quase ausente em grande parte das formulações à efetivação das políticas raciais até a atualidade.

Aparentemente superada a condição social inicial, cumpriu-nos nesse trabalho apresentar argumentos que confirmam, a despeito das mudanças pontuais, uma renitente percepção generalizada que as políticas de ações afirmativas no Brasil, serviram como uma névoa de fumaça capaz de encobrir a responsabilidade do Estado brasileiro na perpetuação do racismo. 


\section{CAPÍTULO 1 - CAPITALISMO E ESCRAVIDÃO NA HISTÓRIA DO}

\section{BRASIL}

Convencionalmente, a história do Brasil é contada por meio de uma periodização que a divide em três períodos básicos: o Brasil-Colônia, o BrasilImpério e o Brasil República, os quais podem ser evocados para compreender a construção do "racismo institucionalizado" do momento colonial (sem Estado autônomo), ao momento monarquista (com a formação de um Estado autônomo e escravocrata) e ao momento republicano (demarcado pela abolição do trabalho escravo e pela introdução do trabalho livre).

É muito recente na história brasileira e, em específico, na própria história republicana - apenas no período pós-Constituição de 1988 -, o caminhar a um estado de coisas em que (por pressão, protagonismo, organização e formulação do movimento negro) se dá a tentativa de se desconstruir 0 "racismo institucionalizado" por meio da adoção de políticas públicas de promoção da igualdade racial e de enfrentamento ao racismo.

Marcado no seu nascedouro por leis e políticas públicas hostis à população negra no pós-abolição, e de forte incentivo ao branqueamento como valor, o momento republicano conheceu muitas fases, tradicionalmente referidas como República Velha (1889-1930), Era Vargas (Revolução de 1930 e Estado Novo), República Nova ou Populista (1946-1964), Ditadura Militar (1964-1985) e Nova República (de 1985 até os dias de hoje).

Segundo estudiosos no campo jurídico, a análise da legislação brasileira permite flagrar os marcos legais reveladores do papel indutor do Estado na institucionalização do racismo e na garantia legal das práticas racistas, durante - Brasil-colônia e Brasil-Império - e após a escravidão - Brasil-República.

De acordo com Samuel Vida,

A abordagem crítica hegemônica no seio dos movimentos negros aponta a omissão do ente estatal como reveladora do 
descompromisso com a superação das desigualdades sócio raciais. Entretanto, não se pode fala em omissão estatal no tocante à questão racial. Pelo contrário. O racismo brasileiro, apesar do apartheid não codificado, sempre teve no Estado um agente impulsionador, e no Direito um eficaz instrumento de controle social, legitimação e naturalização das desigualdades. (VIDA, 2005, p.83).

Na longa história dos dispositivos legais sobre a escravidão no Brasil, a independência assinala uma descontinuidade institucional importante, assinalada pela dissolução da ordem estatal colonial e pela formação de uma nova ordem estatal, com o passo da Colônia à Independência.

Todavia, a manutenção da escravidão dentro da nova ordem social e estatal levou o sociólogo brasileiro Florestan Fernandes a afirmar que nossa Independência foi uma "descolonização congelada", porque não apenas não rompera com a escravidão, a base do poder social que o mundo da colônia construíra, mas passava a se beneficiar dela.

Um ponto fundamental desta tese, para não nos restringirmos apenas ao campo da superestrutura, é resgatar brevemente as atividades econômicas que se estruturam nos três primeiros séculos da colônia, no intuito de demonstrar o sentido e fundamentos da escravidão para a consolidação da nação brasileira.

A singularidade com que se constituiu a escravidão remete-nos a indagações quanto às estratégias de constituição e manutenção do sistema e consolidação da colônia. Decorrente disso, até hoje temos questões cruciais não resolvidas como legislações específicas para o reconhecimento das terras remanescentes de quilombos e o papel do Estado enquanto indutor de políticas mitigadoras dos processos de exclusão social vividas pela população negra.

Portanto, busca-se compreender as estratégias que permitiram aos colonizadores manter um sistema de exploração da mão-de-obra escrava e construir um projeto de povoamento capaz de abrigar uma parcela significativa de trabalhadores livres europeus, cujos países atravessavam uma crise baseada no aumento populacional, bem como passavam por profundas mudanças nas relações de trabalho, o que abre caminho para a introdução de um elemento novo nas relações de trabalho.

Esse imbricado processo da evolução estrutural do escravismo permite pôr às avessas o longo período de utilização da mão-de-obra negra como epicentro de relações assimétricas e coisificadas, e explicitar os fundamentos 
históricos e econômicos que deram sustentação à escravidão dos negros, os quais até o momento atual sofrem os reflexos das mazelas escravistas do passado.

MATRIZ COLONIAL

Interessa-nos pensar que a sociedade em desenvolvimento a partir da colônia, no decorrer do séc. XVI ao séc. XIX, passou por profundas e complexas transformações sociais ainda pouco exploradas na identificação das razões da permanência dos fatores de desigualdades ainda hoje presentes na sociedade brasileira.

Trata-se de questão crucial para a compreensão dos fatores determinantes da formação econômica e social da nação brasileira. Se tomarmos a história de forma linear a partir de estágios evolutivos dos modelos de produção, incorremos no risco de limitar o escopo da análise de forma a reiterar processos sucessivos que esvaziam de sentido as contradições e as justaposições de sistemas interagindo e influenciando na sociedade a partir das manifestações dos envolvidos.

Esses dilemas que acompanharam as narrativas e o desenrolar da história de constituição da nação brasileira, se cuidadosamente observados, revelam um processo dúbio sobre a importância do negro enquanto mola propulsora de uma economia que variou de acordo com as oscilações das relações de trabalho e do grau de desenvolvimento das forças produtivas.

Vale ressaltar que as relações trabalhistas no período em questão não se entendem segundo as concepções mais clássicas do conceito de trabalho, concebido por Marx. Há um limbo conceitual quando se busca caracterizar esse conceito aliado a escravidão. Se, para Marx, a categoria trabalho está ontologicamente vinculada ao ser social e às interações do indivíduo em sociedade, para os negros escravizados, essa dimensão não os alcança.

Aqui reside mais uma das pistas possíveis para se compreender a dimensão e alcance da escravidão enquanto realização de relações produtivas 
determinadas historicamente. O trabalho compulsório dos negros escravizados, para além de atender ao capital interno em formação, tinha precipuamente a necessidade de contribuir em grande escala com a produção agrícola mundial, em especial do açúcar.

Essa digressão nos permite lembrar que em meio ao processo de consolidação da colônia havia um interesse muito maior que a definição do parâmetro de constituição de uma burguesia local. Para além de um modelo econômico aqui inserido, a produção escravocrata também objetivava atender a expansão capitalista no mundo; o mercado europeu se nutriu da produção agrícola fruto da mão de obra escravizada. A escravidão brasileira financiou o crescimento e a expansão do capitalismo europeu, como bem afirma lanni (1993).

A economia colonial representava uma síntese complexa de um determinado modelo econômico hibrido. Suas determinações econômicas irão se aliar a uma matriz cultural cujos pressupostos estão baseados na dimensão estrutural da escravidão.

Com efeito, para esse estudo, trata-se de elencar três fatores que deram suporte a esse modelo híbrido: as relações de dominação, a autoridade e a dimensão material. Esses determinantes compuseram o pano de fundo da nascente sociedade de classes no período colonial.

De acordo com Patterson,

Ao escravo não eram negados todos os direitos e obrigações para com seus pais e parentes vivos mas, por extensão, todos os direitos e obrigações para com seus mais remotos ancestrais e seus descendentes. Ele era, de fato, um isolado genealógico. Formalmente isolado de suas relações sociais com aqueles entre os quais vivia, ele também estava culturalmente isolado da herança social de seus antepassados. É obvio que ele tinha um passado. Mas um passado não é uma herança. Tudo tem uma história, até pedras e paus. Os escravos diferiam dos demais seres humanos no sentido de que não Ihes era permitido integrar livremente em suas vidas e experiência dos antepassados, orientar sua compreensão da realidade social com os significados herdados de seus ancestrais naturais, ou atrelar 0 presente vivido a qualquer associação consciente de memória. Não há dúvida de que eles se voltavam para o passado, assim como buscavam se relacionar no presente. Ao contrário de outras pessoas, tal ação significava lutar contra e penetrar a cortina de ferro do senhor, sua comunidade, suas leis, seus policiais ou patrulheiros, e sua herança. (PATTERSON, 2008, p.24. Sem destaque no original). 
Nesse sentido ao trazer à análise a dimensão da escravidão e a condição social do negro escravizado, parte-se de um determinado princípio que fundamenta as contradições nas relações sociais entre senhores proprietários e negros escravizados, com base nas interações sociais do período em questão.

A colonização possibilitou essa dupla definição quanto à propriedade, as terras - através da doação de sesmarias -, enquanto um bem tangível, compunham parte significativa das riquezas do senhor, o qual dependeria de trabalhadores capazes de multiplicar o valor de suas riquezas. Esses mesmos senhores provocaram o fomento do tráfico de negros como recursos para ampliar a produção e a acumulação primitiva de capital.

Importa ressaltar que a acumulação primitiva de capitais constituiu-se em um dos pilares do nascente capitalismo e, isso, em atrelamento à escravidão, o que caracteriza uma forma bastante peculiar do modelo econômico vigente à época. Destarte, na historiografia atual, um dos principais problemas que se levantam ao tratar da escravidão é separar a escravidão do modo de produção econômica, como se o fenômeno da escravidão fosse apenas relativo a seres humanos (PATTERSON, 2006)

A espoliação sofrida pelos negros nem sempre é interpretada como a base fundamental do capitalismo, a despeito do quanto os clássicos reconheceram o peso da violência extra-econômica na configuração das bases da economia plenamente capitalista:

Todavia, Marx - após ter analisado sistematicamente o mundo do
capitalismo em sua necessidade e compacticidade econômica
rigidamente determinada por leis - expõe num capítulo particular a
sua gênese histórica (ontológica) a chamada acumulação primitiva,
uma cadeia secular de atos de violência extra econômicos somente
mediante os quais foi possível a criação das condições históricas que
fizeram da força de trabalho aquela mercadoria especifica que
constitui a base das leis teóricas da economia do capitalismo.
(LUKÁCS, 1979.)

Portanto, identificam-se alguns fatores de fundamental importância no sentido de analisar as injunções que permearam o debate em torno da questão racial brasileira. Algumas teorias não parecem suficientemente explicativas 
para dar conta de compreensão da persistência da discriminação racial enquanto determinante nas relações de caráter político e econômico.

As idéias que fizeram parte do longo processo de consolidação dos estados nacionais, sobretudo na América Latina, tiveram aspectos relevante na consolidação politica das identidades nacionais, quando se pôs a dimensão do padrão de nação com base em referenciais culturais, linguísticos e raciais eurocêntricos.

Entretanto, é perceptível na análise das literaturas pesquisadas que 0 simulacro em torno da questão racial reflete o deslocamento dessas análises quanto ao papel central dos elementos étnicos raciais na compreensão das relações trabalhistas, ordenando escolhas quanto a negar vestígios da escravidão, procurando inserir de forma "mágica" o trabalhador negro.

Não se tratando de uma simples escolha, esse movimento significou a tentativa de negar as tensões existente entre negros e brancos com a mediação do Estado. Sem embargo, as escolhas protagonizadas pelo Estado ficaram muito evidentes quando da formulação das legislações para manutenção da ordem e da estrutura que hoje percebemos.

Reflexo das revoluções burguesas ocorridas na europa, aqui teremos arremedos de organizações societárias que iriam em direção ao modelo europeu pretendido, porquanto o projeto de nação mobilizou e incorporou muitas das teorias em torno das políticas nacionalistas com forte apelo racial a luz do pertencimento étnico-racial marcadamente branco.

\section{COMPLEXIDADE DA ECONOMIA COLONIAL BRASILEIRA}

Ao traçar alguns paralelos explicativos entre os sistemas produtivos escravistas na Europa e os da colônia à época, deve-se levar em consideração os três fatores da produção: terra, trabalho e capital, segundo as percepções de Furtado (2006).

A singularidade está no modo como a indústria açucareira teve início. Aqui se investia em grandes engenhos a despeito do que ocorria nas ilhas do Atlântico e isso teve papel fundamental na importação de mão de obra especializada, inicialmente no sentido de implantação das usinas. 
Com a chegada de colonos, o sistema de povoamento vai tomar impulso, propiciando assim uma demanda cada vez maior dos produtos de subsistência e de consumo. O crescimento populacional e as primeiras movimentações dos centros urbanos demandaram arranjos de atividades manufatureiras.

Nesse cenário, o Brasil-Colônia se via diante de um novo formato de organização política econômica e social. Portugal passava a investir, nas afirmações de Furtado (2006), em uma rentável e promissora colônia, pois advinda nesse contexto globalizado, a colônia brasileira tornara-se o principal centro produtor de açúcar no mundo.

Para tanto, as primeiras iniciativas de investimento do Estado português foram no sentido de financiar a formação de colonos em técnicas necessárias à produção de larga escala, o crédito fácil para aquisição de maquinários e o fomento da compra de escravos. Dessa forma, nasce uma imbricada relação entre o Estado português e os novos proprietários.

Isto é um fator histórico essencial para a compreensão da terra e do escravo como dois principais fundamentos da economia colonial, em paralelo ao papel que capital e trabalho desempenhavam como fundamentos da nascente economia capitalista.

Nesse ponto, interessa cotejar o surgimento da dimensão do capital na perspectiva marxista, segundo a qual:

\footnotetext{
A circulação das mercadorias é o ponto de partida do capital. A produção de mercadorias e o comércio, forma desenvolvida da circulação de mercadorias, constituem as condições históricas que dão origem ao capital. O comércio e o mercado mundiais inauguram no século XVI a moderna história do capital (MARX, 2008, p. 177).
}

Dessa forma, as primeiras formas do capitalismo no Brasil, e seu enredamento com o contexto político, apresentam-se com características muito específicas. A despeito das diversas formas assumidas em outros países (Espanha, Portugal, Holanda, França e Inglaterra), o modelo que se configura na então colônia portuguesa tem fundamento em alguns fatores decisivos.

Com efeito, a coexistência de dois sistemas em gestação, o capitalismo e a escravidão, faz razoável pensar que as adaptações adotadas aqui 
permitiram a estruturação de um modelo econômico peculiar diferente dos modelos de economia existentes.

O caráter distinto desse novo modelo econômico toma forma à medida que a manutenção do sistema colonial e a necessidade de expansão da produção encontravam obstáculos de várias ordens associados à força de trabalho. Em um primeiro momento, como aumentar a produção com difícil e escassa mão de obra escravizada indígena?

Num outro momento, já na fase do Brasil-Império, de que forma atrair a mão de obra do trabalhador livre europeu, sem que isso signifique aumento de despesas? Essas questões estavam postas em paralelo à necessidade de constituição de um estado autônomo e capaz de conduzir sua própria economia.

Deve-se levar em consideração que, se por um lado, em uma observação breve, parecem-nos incompatíveis esses dois modelos quanto às definições e papeis que sua estruturação exige, por outro lado, temos a combinação que dá a esse contexto um caráter muito distinto dos tradicionalmente conhecidos sistemas econômicos.

Nossa hipótese é de que a colônia, em seu período mais importante de produção econômica, vivenciou seu momento mais complexo, por não se configurar totalmente como uma economia baseada na escravidão, e, ao mesmo tempo, não ter ainda as bases do capitalismo assentado na necessidade do livre mercado que exige, também, a livre circulação de mãode-obra.

Ainda que na Europa esse sistema já se configurasse em direção a uma consistente formulação capitalista, teve aqui uma adequação às condições reais da então colônia. A dinâmica do capitalismo em termos da contradição entre capital e trabalho aqui tinha um elemento a mais, representado na figura do negro escravizado.

Já no início do século XIX, de acordo com Lago (2014, p.38), a população brasileira, com relativo crescimento populacional, ainda retinha 0 trabalho escravo como fator relevante para a produção dos bens necessários a sua manutenção, em especial nas atividades agrícolas.

Vale ressaltar que, 
Durante os primeiros séculos da história brasileira, a organização do trabalho variava dependendo da região e da atividade econômica, e a escravidão estava presente na agricultura em todas as regiões, fosse como forma de trabalho predominante ou complementar. (LAGO, 2014).

No processo do desenvolvimento histórico, pode-se depreender que não havia ainda uma produção capitalista desenvolvida, o que nos leva a supor que a interação entre os dois modelos - escravista e capitalista - perdurou até que houvesse uma efetiva instalação de uma classe burguesa.

Não se tratava apenas de lidar com as relações de exploração e as forças produtivas, mas também de lidar com esse fator extemporâneo que é essa figura a qual não se aplica a condição de trabalhador e de uma força de trabalho disponível como mercadoria e meio de produção. É talvez nesse aspecto que reside um dos pontos em destaque desta tese, ao propor uma análise quanto aos aspectos lacunares dos estudos economicistas, principalmente no tocante à abordagem da presença negra nesse contexto.

Se temos uma realidade plasmada na introdução dos princípios do capitalismo europeu, com suas definições bastante precisas quanto à tensão sempre presente entre exploração e resistência dos trabalhadores, a questão é como inserir a participação desses que não são classificados nem como classe nem como trabalhador assalariado.

\section{RELAÇÕES DE PRODUÇÃO, SOCIEDADE E RAÇA}

As contradições observadas a partir da realidade brasileira dispõem de particularidades que tornam muito específica a análise sobre relações de produção, relações sociais e pertencimento étnico-racial ${ }^{3}$.

É essencial estabelecer um ponto de confluência entre as relações sociais e as relações de produção, tomando como parâmetro o binômio

${ }^{3}$ Refiro-me a pertencimento étnico racial-por comportar não apenas a etnia negra, mas também essa amalgamação de uma nação com composição racial multivariada. Para efeito de consideração, trato nesse ponto especificamente das três variações raciais: negros, indígenas e brancos. No entanto, no decorrer do trabalho, assumo estritamente a análise referencial da população negra. 
escravidão/racismo enquanto elemento fundamental para o aprofundamento da realidade social do negro na sociedade atual.

Desconstruir a concepção unitária historiográfica do nascente capitalismo brasileiro passa pela interpretação das diferenças existentes quanto ao status com que cada segmento social era visto. $E$ isso tem efetivamente reverberação nas percepções atuais da noção de cidadania e da expectativa de direitos.

O cenário de séculos de conflitos sociais, aliado ao racismo científico e ao direito de propriedade, não pode ser minimizado em detrimento das lutas desse período. O modelo híbrido plasmado na reconfiguração do capitalismo nas terras brasileiras pode sinalizar arranjos distintos de conformação de uma cidadania peculiar.

A emergência do capitalismo nacional exigia a consolidação de um modelo democrático, em que o pertencimento nacional se dava pela integração ao mundo do trabalho, mas, no entanto, isso estava restrito a poucos. As políticas de integração tinham um caráter seletivo com bases raciais, o que veio ao encontro do momento em que a nação preparava os pilares da sociedade pós-abolicionista, inspirada pela revolução francesa, sem, contudo, garantir e efetivar as condições igualitárias para os negros recém-libertos.

A conjunção do modelo capitalista inaugurado na colônia concorreu com as configurações sociais estabelecidas na construção de relações pretensamente harmoniosas entre os imigrantes europeus e os negros. Concomitante aos arranjos locais é importante lembrar que as idéias eugenistas e as teorias racistas estavam em franco desenvolvimento na Europa do século XIX.

O controverso debate em torno de uma identidade nacional, terminou por promover intensos debates na constituição de um arcabouço explicativo capaz de dar sentido a idéia de nação. A categoria de "raça", a expressiva presença negra, no Brasil como em outros países, era a questão de destaque na definição e consolidação do Estado-Nação. Em torno da forma de identificação popular das diferenças fenotípicas(aparencias), brancos/negros, claros/escuros, 
mantêm-se ao longo da história da humanidade os privilégios de classe, levantam-se barreiras imigratórias, legitimam-se discriminações alfandegárias, construiram se e constroem-se identidades culturais e nacionais (SODRÉ, 1999, p.9)

Possuidora de um doloroso passado histórico enquanto foco central do processo escravocrata no Brasil a população negra concentrava os membros do grupo estigmatizado, racializado e excluído das perspectivas igualitárias no interior da sociedade em cuja construção teve sua forte contribuição na edificação de sua base produtiva.

Importa trazer ao debate que esse momento é fundamental para a compreensão do papel central da dimensão racial na conformação de um modelo branco de sociedade que refletisse as aspirações de atenuação da marca negra no interior da nação brasileira.

O principal determinante da construção de um modelo de nação com bases nas teorias eugênicas oriundas da Europa decorreu, sobretudo, de uma necessidade de atender a demandas de não transformar a nação brasileira em uma nação segmentada pela presença negra e indígena. em detrimento do pesado investimento do Estado em constituir-se em uma sociedade assimilada aos padrões brancos do chamado mundo moderno.

A ausência da coesão social observada, sobretudo, a partir da República, tem efetiva relação com as lacunas deixadas pela incorporação de um projeto de sociedade idealizado a partir da suposta democracia igualitarista, que terminou por definir uma democracia em que em suas bases estava voltada para uma pequena parcela de proprietários e colonos imigrantes.

A partir de uma pretensa superioridade genética confirmada pelo cientificismo do século XIX, com base no Darwinismo e no evolucionismo spenceriano, as teorias racistas tiveram aceite, incluindo nisso a perspectiva modernizadora das relações trabalhistas.

As conformações econômicas que influenciaram o ingresso do país na chamada modernidade parecem não ter levado em conta as exigências do capitalismo mundial dessa modernização, as quais exigiriam adequações de caráter político, social, cultural e econômico para sua efetivação. 
A colônia brasileira, ao se constituir como fonte promissora do capitalismo industrial, em franco desenvolvimento na Inglaterra e demais países da Europa, vai subsidiar uma profunda mudança nas relações de produção.

Por outro lado, a exigência cada vez maior de ampliação do capital e a expansão de um mercado internacional irão promover constantes mudanças nas relações de trabalho, nas relações sociais e no modo de funcionamento do Estado exigido pelo capitalismo, alterando o funcionamento da relação de produção baseada no trabalho escravo.

O antigo escravizado, na condição agora de proprietário de sua força de trabalho, teria que se adequar às novas exigências de produtividade para 0 lucro. $O$ antigo senhor, com sua produção em pequena escala, baseada na exploração do trabalho escravo, teria que se adaptar à produção em crescente escala maior, fundamentada na exploração da força de trabalho livre e no aumento de produtividade.

É nesse momento de efervescência política brasileira ${ }^{4}$ que se observam, como pano de fundo, os desafios deixados para trás, entre eles o de se pensar uma sociedade inclusiva. Ao ser pensada, essa sociedade inclusiva não levou em consideração o papel marcante do racismo, uma vez que o nascente capitalismo se concretizou de maneira mais fecunda utilizando como fundamento o racismo enquanto estrutura ideológica.

Se, no primeiro impacto, as relações escravistas tornam-se obsoletas para a produção em larga escala, dando lugar à produção baseada na exploração do trabalho livre, as transformações da estrutura econômica irão dimensionar em essência as relações sociais, sem, contudo, modificar as relações entre negros e brancos.

4 Para lanni, a contradição marcante está nas exigências de modernização das relações de produção capitalistas quanto à utilização da mão de obra escravizada; a insustentabilidade está na adequação desse antigo modelo escravista às novas demandas de lucro, flexibilização dos empreendimentos e, fundamentalmente, na transformação da mercadoria humana (escravizado) em trabalhador livre. Ainda no conjunto das transformações desse período, há em curso um conjunto de acontecimentos que promoverão mudanças no plano do sistema econômico e, consequentemente, nos planos sociais e políticos, a exemplo das rebeliões quilombolas, espalhadas pela antiga colônia, da guerra do Paraguai, do movimento abolicionista, da própria abolição. (IANNI, 1972, p.7). 
Com isso, cria-se um movimento capaz de promover rupturas nas relações entre trabalhadores livres, oriundos da imigração financiada pelo Estado, e a dispensa dos negros recém-libertos por esse mesmo Estado.

É partir de uma ideia de nação que se observa a construção de valores quanto ao pertencimento nacional. Desta forma, o Brasil se consolidou como espaço plural dotado de uma cultura que se desejava homogênea.

Nesse sentido, a principal ideia para a efetivação desse modelo social teve no período pós-abolicionista seus momentos mais efervescentes, uma vez que a antiga colônia se deparou com um dilema relevante: como construir as bases da modernidade com uma população majoritariamente negra? De que forma fomentar a constituição de uma nação com essa diversidade cultural, fruto da necessidade temporal da produção?

Um amplo debate ocorre no final do século XIX, momento em que as perspectivas de manutenção do modelo escravista não comportavam mais as expectativas do mercado agroexportador. Para além de ajustes na economia, era necessário alterar também as relações sociais, e, sobretudo, fomentar o consumo interno.

Apresenta-se uma situação que assinala dois problemas, um de ordem econômica, e outro de ordem cultural. No campo econômico a solução encontrada para dissolver a ordem escravocrata apresenta contradições, pois nega a possibilidade de uma parcela significativa de ex-escravizados de possuir o status de cidadania e, com as prerrogativas próprias desta, acesso a direitos e bens, sobretudo de consumo e direito de propriedade.

No campo cultural, permanece a questão: como amalgamar valores tão dispares para a constituição de uma nação com as características das nações modernas da Europa? As tensões e contradições não estavam apenas na perspectiva econômica, mas sobre sua base, ou seja, nas determinações sociais e culturais que se pretenderam "passadas" com o fim do escravismo e condicionaram os fatores conjunturais que sedimentaram as causas originárias das desigualdades econômicas e raciais.

Portanto, ao se desvelar essas questões, expõe-se a importância da ideia de nação (e da república, entendida como um "segundo batismo" da nação) enquanto narração cultural, pois se ampliam as possibilidades de articulações simbólicas deste evento, com diferentes categorias como raça, 
gênero, classe, e diferença cultural, fator que abordaremos ao final do próximo capítulo, discutindo a ideologia do branqueamento como resistência à integração da população negra.

\section{CAPÍTULO 2 - MENTALIDADE RACIAL E HEGEMONIA NA CONSTRUÇÃO DA SOCIEDADE BRASILEIRA}

Talvez o principal desafio na atualidade para se pensar o Brasil resida na perspectiva de uma profunda e dolorosa revisão dos elementos que estruturam a ideologia republicana de conformação do país no que diz respeito a suas aspirações euroetnocêntricas.

Pautado por uma ideia de unidade dentro da diversidade étnico-racial, em que originariamente a figura do nativo vai aos poucos se aproximando do negro, não como forma de amalgamação racial, mas sobretudo enquanto um obstáculo a essa unidade do Estado-nação.

Os debates atuais apresentam diversas perspectivas de análises, no entanto há fragmentações que permanecem insolúveis dado a persistente negação do racismo nacional. Mesmo os estudos mais específicos em torno do racismo brasileiro, ao buscar sua significação e sentido no seio da sociedade, distanciam-se dos fundamentos que estruturaram e edificaram o Estado moderno brasileiro com base no racismo.

Importa, aqui, reafirmar que o Estado foi, ao mesmo tempo, estruturado pelo racismo, como também foi indutor do racismo. $O$ processo gradual de consolidação desse Estado-nação esteve marcadamente pautado pelas ideias 
colonizadoras e de anexação de povos oriundos da Europa, com forte apelo a assimilação das denominadas culturas superiores.

$O$ interesse desse estudo vem na direção de demonstrar que o desinteresse histórico não se trata de uma escolha aleatória por esse ou aquele ponto de partida, mas trata-se de uma escolha. Escolha epistemológica, na medida em que se pode delimitá-lo na hoje farta bibliografia acerca do período que compreende o final do séc. XVIII a meados do séc. XIX, período marcado pelo amplo debate em torno do projeto de nação com base no modelo hegemônico europeu. $O$ processo de imigração, sobretudo, consolidado para 0 sul do país, onde ensejou a assimilação de uma massa de trabalhadores considerados laboriosos e afeitos as aspirações sociais em curso.

Por outro lado, esse estudo tem a opção de explicitamente estabelecer um corte radical na ideologia ainda muito perene nos estudos sociais de que as diferenças observadas na sociedade brasileira são apenas fruto da amalgamação voluntária dos povos aqui irmanados em torno de um projeto civilizatório que teve seu epicentro na economia em desenvolvimento.

Mais que descrever os fatos de maneira quase linear, importa mostrar a dinâmica da identidade racial com bases nas interações desses grupos através de processos de escolhas com base no pertencimento étnico-racial.

Indubitavelmente, o país não passou ao largo das ideias e ideais racistas europeus, mas dado o caráter laboratorial com que se constituiu 0 amplo debate para a recém-constituída nação, os processos de organização social tiveram contribuições e influências de um imaginário marcado pela negação e indiferença ao "outro" que não o europeu.

É nessa perspectiva que procuramos explicar o recrudescimento lento e gradual das formas de discriminação na atualidade; o fortalecimento do racismo institucional; as práticas genocidas dos órgãos de controle social; as omissões na assistência dos programas sociais, observadas sobretudo através de políticas pobres, ou de reduzido poder de produzir efeitos, que revelam um direcionamento a parcela da sociedade. Parcela essa que esteve no centro dos debates ideológicos quanto ao que fazer com essa massa de não assimiláveis. Concomitante a essas indagações, conformava-se ideologicamente a vocação "natural" de um país igualitarista com base aos ideais republicanos. 
É interessante perceber que, ainda que as características marcantes desses não assimiláveis tenham uma origem comum no caso dos negros, oriundos do continente africano, o debate que o Estado passa a promover não é o de como reconhecer suas principais referências identitárias, mas de como envolve-los nas questões do desenvolvimento.

Sua raça, sua origem, sua religião ao mesmo tempo que não fazem parte das preocupações quanto a valorização e respeito, passam a fazer parte das preocupações quanto a como coibir para não refletir nas aspirações da nacionalidade em construção.

Herda-se portanto, uma configuração em que agora os assimiláveis, são incorporados sem contudo ter havido a integração daquilo que thes constitui enquanto grupo diferenciado, mas sem força política para se afirmar enquanto sujeito histórico.

No decorrer desse trabalho pretende-se evidenciar a doutrina política par-e-passo a doutrina jurídica que irá traduzir-se no melhor instrumento de dominação do problema brasileiro que, por razões nítidas, tem uma dificuldade em tornar-se uma questão racial para o Estado brasileiro, ficando quando muito adstrito ao problema de inadequação desse ou daquele indivíduo que, deslocados de sua origem "primitiva", não conseguem se libertar de seu atávico sentimento de inferioridade.

\section{ABOLIÇÃO: SIGNIFICADOS DE UM MARCO SOCIAL}

$\mathrm{Na}$ introdução desta tese, apontamos a importância da Constituição de 1988, por firmar um marco da elaboração de políticas públicas. $\mathrm{Na}$ introdução do primeiro capítulo, explicitamos quão recente é esta demarcação na história republicana, senão na história do Brasil, remontada ao Império e, sobretudo, a história de formação e desagregação do território americano do império colonial português.

Trata-se de toda uma história plasmada sobre a escravidão negra e sobre o poder estatal que a garantiu, primeiro representado pelo Império Português (primeiro ultramarino e, após, 1808, sediado no próprio Brasil) e, depois, poder político que, prorrogou a escravidão o quanto mais conseguiu. 
Como sublinhamos, a "conta" da existência e da manutenção da escravidão também se aplica aos primeiros 66 anos de vida independente e livre - não para os escravos - do Estado brasileiro, último no mundo a abolir a escravidão.

No livro Raízes do Brasil, Sérgio Buarque de Holanda aponta a abolição como a única verdadeira revolução que conhecemos na nossa história. Escrito pouco após a "revolução de 1930", a frase é cheia de significado numa história como a brasileira, inflacionada de momentos inclusive contra-revolucionários, como o golpe de 1964 - em que as mudanças no poder são apresentadas como "revoluções".

Marco simbólico da instauração dos ideais burgueses de modernidade, a própria república instaurada pela revolução francesa de 1789 não conheceu senão uma caricatura nacional, cem anos depois, motivando o jornalista a dizer que o povo assistiu bestificado à proclamação da república. Em reflexão tardia, em 1958, sobre as razões do fracasso republicano no Brasil, Lídia Besouchet aponta o efeito da escravidão como um elemento básico para pensar a distância entre as elites e o povo:

O unitarismo do Primeiro Reinado - a tentativa federalista das duas regências não frutificou - e o forte centralismo do Segundo Reinado, impediram uma evolução mais natural de nossas culturas regionais com o estancamento das áreas populares especiais. A preponderância do centro, e a formação de eixos (Rio-São Paulo, Rio-Minas Gerais, Rio-Rio Grande do Sul, etc.), num esquema que vai se alternando à proporção que evolui o nosso sistema político, talvez sirva para explicar também a pequena participação das massas populares na direção de nossa civilização, e a isso acrescentando-se a permanência do sistema escravagista como base social.

As grandes extensões territoriais, a falta de comunicações internas (à exceção do São Francisco, o nosso sistema fluvial não prepara uma centralização efetiva mas, ao contrário, sugere uma diferenciação dos diversos centros geográficos indicando portanto um caminho para o federalismo), e o sistema social mantido, deram como resultado um profundo desnivelamento entre as elites e o povo, desnivelamento que se acentuou à medida que os séculos evoluíram e que somente começou a se alterar no século atual.

A famosa tese - litoral e sertão - poderia ser talvez melhor compreendida se a ela acrescentássemos sua antítese - classes possuidoras e classes pobres. A distância entre as elites e o povo, tanto entre as populações rurais, como entre as populações urbanas, tanto no litoral como no sertão, complicando o esquema euclidiano, foi típico e inerente ao sistema escravista, e essa distância não pôde e nem poderá ser anulada por muito tempo de nossa civilização.

Todos os sistemas aplicados no Brasil, desde sua descoberta até a República, todos os ensaios de reformas, todas as 
transformações administrativas e partidaristas durante a Monarquia não atingiram a essência profunda da nação porquanto nela permaneceu o regime do trabalho escravo. (BESOUCHET, 1958, p.56 , grifos nossos).

Faz sentido, todavia, de um ponto de vista marxista, pensar no aspecto revolucionário da abolição da escravidão, em 1888. Afinal, a mudança nas relações de produção é o elemento chave com o qual Marx caracterizou a mudança nos modos de produção.

De acordo com Marx, mas também na perspectiva de seu grande colaborador e divulgador, Friedrich Engels, a mudança nas forças produtivas configura o surgimento de um novo modo de produção, por meio de uma revolução.

As forças produtivas sempre permitem certo desenvolvimento das forças produtivas, mas ultrapassado certo ponto, limiar ou patamar, elas passam a ser entraves para o desenvolvimento pleno das forças produtivas e, por conseguinte, para o desenvolvimento da sociedade em seu conjunto, o que enseja a sua mudança.

Morto em 1896, Engels ainda foi contemporâneo dos debates que marcaram o surgimento da social-democracia e da tese de que a mudança de um modo de produção a outro - notadamente do modo de produção capitalista para um modo de produção socialista - poderia ser operada em termos não revolucionários, estritamente, mas reformistas.

Trata-se do debate sobre reforma ou revolução que, todavia, dificilmente se aplicaria para apreender o quanto a abolição teve também de "contra-reforma" e de "contra-revolução", de uma perspectiva negra.

Inegavelmente, um marco na história do Brasil, por assinalar uma mudança definitiva no plano das relações de produção, o significado histórico do 13 de maio de 1888 foi "disputado" desde então, de acordo com as perspectivas branca e negra, no campo acadêmico mas também no campo da militância. Já há algum tempo - talvez mais explicitamente a partir de 1978, ano da fundação do Movimento Negro Unificado - a data de 13 de maio começou a ser de fato rechaçada pelo movimento negro como uma data comemorativa de uma coisa positiva. 
A culminância deste embate, de um ponto de vista negro, tem a ver a "anti-comemoração" negra do centenário da abolição, em 1988, e com a organização da Marcha Zumbi dos Palmares, em 1995, data que assinalava o Tricentenário da morte de Zumbi dos Palmares.

Desde 1972, pelo menos, os negros brasileiros, a partir da iniciativa de Oliveira Silveira, no Rio Grande do Sul, sugeriam o 20 de novembro como uma data chave para celebrar a consciência negra.

\section{CRÍTICA À DEMOCRACIA COMO DEMOCRACIA RACIAL}

Marcos estabelecidos a partir de determinada compreensão da história, as datas comemorativas sedimentam, alimentam e cimentam determinada versão da história. A aposentadoria do 13 de maio como data comemorativa de algo positivo e a ascensão do 20 de novembro como dia da consciência negra corresponde, sob o prisma negro, à luta pelo reconhecimento de que o Brasil nunca foi uma democracia racial.

Muita coisa já se escreveu sobre o chamado "mito da democracia racial", mas vale a pena dizer que ele tem a ver também com a "disputa" entre as perspectivas branca e negra sobre o significado histórico do 13 de maio de 1888, como data que potencialmente simbolizaria a mudança de uma sociedade em que havia dominação de brancos sobre negros para uma sociedade em que todos teriam oportunidades.

De uma perspectiva negra, a frustração com a perspectiva de que a abolição criara as bases para uma sociedade em que a raça não contaria, senão os méritos, veio logo.

De maneira rápida e organizada, nas associações e nos jornais que publicavam os negros começaram a defender uma "segunda abolição", que viesse instaurar, para valer, uma sociedade em que todos teriam oportunidades. 
A perspectiva da "segunda abolição" tinha a ver com a consciência de que a primeira "não tinha valido, pois os negros continuavam em situação de vida aflitiva". Por muitos anos a consciência de que os negros continuavam subalternizados na sociedade foi colocada na conta da "omissão do Estado" na garantia de condições de integração dos libertos à sociedade baseada no trabalho livre.

Durante os quarenta e cinco primeiros anos (1888-1933) após a abolição, a queixa contra o alijamento das pessoas negras deu o tom da aspiração negra a um tipo de sociedade que fosse democrática de fato. Hoje, quando os negros rechaçam o 13 de maio não mencionam apenas a "omissão do Estado" na criação de condições de integração dos negros à sociedade baseada no trabalho livre.

Contemporaneamente há plena convicção, de um ponto de vista negro, de que o Estado não foi "omisso" ou "indiferente" em relação aos negros - foi pior: o estado baixou leis que visavam distanciar os negros da sociedade que se queria construir, promovendo políticas de branqueamento da sociedade, baseadas, entre outros pontos,

$\checkmark$ Na promoção - subsidiada - da imigração europeia para o Brasil;

$\checkmark \mathrm{Na}$ criação de barreiras à imigração eventualmente proveniente da África;

$\checkmark$ No rebaixamento de 14 anos para 9 anos da maioridade penal;

$\checkmark \mathrm{Na}$ criação da lei da vadiagem, para coibir a circulação de pessoas sem emprego formal;

$\checkmark$ Na criminalização da capoeira;

$\checkmark \mathrm{Na}$ coibição das manifestações religiosas de matriz africana. $\mathrm{Na}$ ausência total de qualquer gesto de reparação ou indenização aos escravos libertos (vale lembrar que existia na época um debate sobre "reparações" para os antigos proprietários de escravos).

Em 1933, surge uma novidade no campo argumentativo dos brancos, com a publicação da obra Casa Grande e Senzala, de Gilberto Freyre. A obra de Freyre generalizava manifestações afetivas presentes na relação pessoal entre senhores e trabalhadores domésticos (mormente mulheres, 
primeiro escravas, depois "empregadas") como um traço caracterizador das relações entre bancos e negros em todas as esferas, desde antes da abolição.

Para Élide Rugai Bastos, ao se concentrar no escravo da Casa Grande e não no escravo do "eito", sobre o qual projetava uma relação de idílio e paz entre senhores e escravos, Freyre desempenhava um papel importante na justificação de que o Brasil não precisava de reforma agrária - ponto crucial numa época em que $70 \%$ da população brasileira gravitava em torno da zona rural.

O fechamento de associações negras e partidos políticos, em 1937, impedindo a circulação dos jornais negros, pesou também para uma circulação sem contraste do argumento freyreano, que passava por antropológico e científico.

$\mathrm{Na}$ década de 1950, no contexto da realização de uma pesquisa encomendada pela Unesco acerca das relações sociais brasileiras, os interesses universitários da emergente ciência social brasileira - principalmente de pesquisadores cariocas e paulistas - levaram a que a obra de Freyre começasse a ser questionada para dar lugar a explicações sociológicas supostamente mais científicas.

Nesse contexto, dentro da elite universitária branca, abre-se espaço a nomes como o de Florestan Fernandes.

O papel de Florestan Fernandes na crítica do "mito da democracia racial" não pode ser subestimado - por haver explorado suas frestas -, mas também não pode ser superestimado - como se o sociólogo tivesse esclarecido os negros sobre um mito em que as pessoas negras nunca creram. Autor que crescentemente se aliou e apoiou as demandas e iniciativas do movimento negro, Florestan Fernandes também se beneficiou profundamente deste contato, iniciado eventualmente e que o marcou por toda vida.

Além disso, crescentemente Florestan Fernandes se aproximou de lideranças negras - do encontro pioneiro com José Correia Leite ao trabalho com Edson Lopes Cardoso, que chefiou seu gabinete por cinco anos, passando pela admiração e amizade com Abdias do Nascimento - e valorizou a força do protesto negro como dado construtivo de uma sociedade democrática de fato, e não apenas formalmente. 
Em 1988, Florestan Fernandes foi um dos destacados intelectuais que subsidiaram a anti-comemoração negra da abolição no ano da promulgação da Constituição de 1988, que já assinalamos como marco legal para a elaboração das políticas públicas de combate ao racismo hoje vigentes.

Mesmo que se possa relativizar o mito que se erige em torno de Florestan, tanto por pela apresentação de novas hipóteses científicas no campo de seus questionamentos - como empreenderam os autores que seguiram a trilha aberta por Carlos Hasenbalg, como mostrou Santos -, é inegável que foi um dos autores que contribuíram para a discussão da formação do mercado de trabalho e para a problematização do racismo como um de seus elementos determinantes.

Como veremos no tópico seguinte, a questão do "mercado de trabalho" não se colocava numa sociedade escravocrata, um ponto crucial para reconstituir o significado do 13 de maio de 1888.

AUSÊNCIA DO MERCADO DE TRABALHO, "CULTURA DO FAVOR" E FRAGILIDADES DA SOCIEDADE CIVIL

Em 1966, Antônio Candido foi um dos primeiros a assinalar que Casa Grande e Senzala, juntamente com Raízes do Brasil (1936) e Formação do Brasil Contemporâneo (1940), de Caio Prado Jr., foram obras fundamentais para compreender a formação do Brasil.

Hoje é lugar comum abordar a obra de Freyre como alimentadora de uma perspectiva branca, mas esta observação também pode ser estendida às obras de Sérgio Buarque e Caio Prado Jr., embora importa mais integrá-las dentro de uma perspectiva crítica do que meramente rotulá-las pejorativamente.

O acento conferido ao poder das relações pessoais, dos contatos - que Roberto Da Matta chamará de "relacional" - nas obras de Freyre e Holanda tinha a ver com a percepção de efeitos de longo prazo de uma sociedade em que a existência do trabalho escravo tinha impedido a formação de uma sociedade civil nos moldes clássicos, assentada no mercado de trabalho. Na escravidão, a força de trabalho não era uma mercadoria que 
livremente se negociava, que mediava a relação entre alguém que era dono dos meios de produção e alguém que, reduzido à condição de mero proprietário de sua força de trabalho - isto é, "proletarizado" - precisava vender sua força de trabalho para conseguir o dinheiro necessário para sustentar a si e a sua família.

Assim, o favor, o jeitinho e os apadrinhamentos eram os expedientes disponíveis a toda uma classe de pessoas que nem era proprietária e nem era escrava. Nelson Werneck Sodré as caracterizou como "pequena burguesia", mas Roberto Schwarz foi mais preciso, falando em classe dos "homens livres porém dependentes".

De acordo com Sodré, o ciclo econômico da mineração permitiu a existência maior de pessoas que nem eram latifundiárias, proprietárias de escravos, nem escravas, propriamente ditas. Porém, como não havia um "mercado de trabalho" onde poderiam vender sua força de trabalho para garantir seu sustento, sua sobrevivência quase sempre passava por se aproximarem de um poderoso a quem cativavam, lustravam, defendiam, se preciso fosse, em busca de algum tipo de colocação, remuneração, favor.

Essa classe começou a se formar por volta de 1750, segundo Sodré. Este é o período em torno da qual nasceu toda a geração envolvida com a independência (Tiradentes nasce em 1749; D. João VI, em 1776; Pedro I,1798) e a imprensa brasileira (Cipriano Barata, patriarca da liberdade de imprensa no Brasil, nasce em 1762; Hipólito da Costa, editor do pioneiro Correio Braziliense, em 1774), fundamental na batalha das ideias de emancipação nacional, mas nem sempre da emancipação dos escravos.

É importante assinalar que entre estes homens livres havia também negros, entre os quais se contam, inclusive, pioneiros da imprensa e da literatura, a exemplo de Paula Brito, nascido em 1808, Teixeira de Sousa, autor de O Filho do Pescador, para muitos, primeiro romance publicado no Brasil. Da gráfica de Paula Brito, surgiram muitos jornais importantes no período da regência, entre os quais $O$ Homem de Cor, apresentado como primeiro título da imprensa negra brasileira.

Nas páginas desta primeira imprensa negra de que se tem notícia, o jornal "O Homem de Cor" estampava, no cabeçalho de todos os seus números conhecidos o parágrafo XIV do Artigo 179, Título 8ㅇ - "Das 
Disposições Geraes, e Garantias dos Direitos Civis, e Políticos dos Cidadãos Brazileiros" - Constituição de 1824, de acordo com o qual "Todo o cidadão pode ser admitido aos Cargos Públicos Civis, Políticos, ou Militares, sem outra diferença, que não seja a de seus talentos".

Trata-se do princípio da "meritocracia", implícito no ideário da igualdade de oportunidades para todos, presente no ideário moderno.

O próprio Machado de Assis, ao estrear como cronista, nas páginas da revista semanal $\mathrm{O}$ Espelho, dirigida por Francisco de Paula Brito, e após tecer um amplo elogio às virtudes do jornal na propaganda política lamenta que, entretanto, é difícil ter acesso unicamente pelo mérito às suas páginas:

Tremem, pois, tremem com este invento que parece abranger os séculos - e rasgar desde já um horizonte largo às aspirações cívicas, às inteligências populares.

E se quisessem suprimi-lo? Não seria mau para eles; o fechamento da imprensa, e a supressão da sua liberdade, é a base atual do primeiro trono da Europa.

Mas como! cortar as asas de águia que se lança no infinito, seria uma tarefa absurda, e, desculpem a expressão, um cometimento parvo. Os pergaminhos já não são asas de ícaro. Mudaram as cenas; o talento tem asas próprias para voar; senso bastante para aquilatar as culpas aristocráticas $e$ as probidades cívicas.

Procedem estas ideias entre nós? Parece que sim. É verdade que o jornal aqui não está à altura da sua missão; pesa-lhe ainda o último elo. Às vezes leva a exigência até à letra maiúscula de um título de fidalgo.

Cortesania fina, em abono da verdade!

Mas, não importa! eu não creio no destino individual, mas aceito o destino coletivo da humanidade. Há um polo atraente e fases a atravessar. - Cumpre vencer o caminho a todo o custo; no fim há sempre uma tenda para descansar, e uma relva para dormir.

Interessa ver como, na primeira parte da crônica, Machado esboça toda uma teoria da relação entre comunicação, agitação e revolução ("reforma", no seu vocabulário), mas imaginando-a protagonizada por um sujeito, o operário, que precisamente era o que não existia no Brasil em 1859:

A primeira propriedade do jornal é a reprodução amiudada, é o derramamento fácil em todos os membros do corpo social. Assim, 
o operário que se retira ao lar, fatigado pelo labor quotidiano, vai lá encontrar ao lado do pão do corpo, aquele pão do espírito, hóstia social da comunhão pública. A propaganda assim é fácil; a discussão do jornal reproduz-se também naquele espírito rude, com a diferença que vai lá achar o terreno preparado. A alma torturada da individualidade ínfima recebe, aceita, absorve sem labor, sem obstáculo aquelas impressões, aquela argumentação de princípios, aquela arguição de fatos. Depois uma reflexão, depois um braço que se ergue, um palácio que se invade, um sistema que cai, um princípio que se levanta, uma reforma que se coroa.

$\mathrm{Na}$ verdade, o jornal não podia funcionar aqui como expressão na "esfera pública" de uma luta que acontecia no plano da "sociedade civil", entre operários e patrões, que começavam a disputar o poder político e o poder de Estado A ausência de um mercado de trabalho, implicava na ausência dos sujeitos e dos predicados clássicos da teoria política.

Muitos anos depois, já escritor consagrado, a 11 de maio de 1888, ou seja, a dois dias da Abolição, registra em crônica muito irônica a frase de um jornal dirigido à colônia alemã, segunda o qual: o Brasil está mais para uma oligarquia absolutista que para uma monarquia constitucional e se pergunta que flor (ou que república) poderia nascer dessa planta (uma sociedade oligárquico-absolutista).

O ceticismo de Machado em relação à abolição e à república, como um ideal pelo qual se porfiava desde a década de 1870, tinha a ver com a profunda relativização pela qual passaram as ideias modernas após 66 anos de convivência com a escravidão, naquela situação que a "descolonização congelada", no dizer de Florestan Fernandes forjara.

\section{CONSTITUIÇÃO DE 1824, ABOLICIONISMO E INCORPORAÇÃO NEGRA À NAÇÃO}

Como assinalam historiadores como Fernando Novais, a opção pela forma política da monarquia (em vez da republicana) e pela manutenção da escravidão (em vez da pronta abolição) correspondeu a mais conservadora das opções realizadas pelos estados-nação que se formavam com a desagregação do sistema colonial nas Américas do Norte, Central e do Sul.

Valorizador da democracia - desde a Constituição estadunidense, proclamada anos depois de sua independência (1776) - e 
também da república, de principalmente com o exemplo da revolução francesa (1789), que terminaria por cortar a cabeça do monarca, o ideário moderno estava largamente incorporado à constituição de 1824, na qual todavia, é preciso assinalar que não havia senão parcas referências àquilo que dava sustentação material a tudo: a escravidão.

Quanto a este aspecto vale retomar alguns momentos de "O abolicionismo", libelo publicado por Joaquim Nabuco em 1863, e atualizado nas sucessivas reedições ao longo da campanha abolicionista. Nabuco frisa a existência, nos anos em que acontece a independência, de muitos simpatizantes da necessidade de compatibilizar a emancipação política nacional - "a causa da Independência" - com a emancipação dos escravos.

Depois de analisar um documento da Revolução de 1817, em Pernambuco, em que reconhece - ou atribui, confere, empresta - grande realismo ao admitir a dificuldade de atrair os fazendeiros para a base política de apoio à independência e, ao mesmo tempo, agir contra a escravidão, Nabuco afirma - em se referindo à diferença existente entre o projeto da Constituinte, dissolvida em 1823, e a Constituição, finalmente outorgada por Pedro I:

[...] no Sul a causa da Independência esteve intimamente associada com a da emancipação, prova-a a atitude da Constituinte e de José Bonifácio. Aquela em um dos artigos do seu projeto de Constituição inscreveu o dever da assembleia de criar estabelecimentos para a "emancipação lenta dos negros e sua educação religiosa e industrial". A Constituição do Império não contém semelhante artigo. Os autores desta última entenderam não dever nodoar o foral da emancipação política do país, aludindo à existência da escravidão, no presente. A palavra libertos do artigo pelo qual esse são declarados cidadãos brasileiros e do artigo 94, felizmente revogado, que os declarava inelegíveis para deputados, podia referir-se a uma ordem anterior à Constituição e destruída por esta. No mais os estatutos da nossa nacionalidade não fazem referência à escravidão. Essa única pedra, posta em qualquer dos recantos daquele edifício, teria a virtude de convertê-lo com sua fachada monumental do artigo 179 num todo monstruoso. Por isso os organizadores da Constituição não quiseram deturpar a sua obra descobrindo Ihes os alicerces. José Bonifácio, porém, o chefe desses Andradas - Antônio Carlos tinha estado muito perto do cadafalso no movimento de Pernambuco - em quem os homens de cor, os libertos, os escravos mesmos, todos os humildes da população que sonhavam a Independência tinham posto a sua confiança, redigira para ser votado pela Constituinte um projeto de lei sobre os escravos. [Grifos nossos; grifo original omitido]. 
Ao se referir aos irmãos Andrada, com destaque especial a José Bonifácio, Nabuco destaca-lhe a percepção de que a manutenção da escravidão era incompatível com aspirações nacionais mais amplas. Elegendoo como uma espécie de patrono da obra que o abolicionismo deveria ter, em pensando as condições para o escravo se libertar e para o escravo forro ter meios - terra, notadamente - para se sustentar a si e sua família, Nabuco transcreve lhe artigos do anteprojeto constitucional abortado em 1823:

Artigo 5. Todo escravo, ou alguém por ele, que oferecer ao senhor o valor por que foi vendido, ou por que for avaliado, será imediatamente forro.

- Artigo 6.Mas se o escravo ou alguém por ele, não puder pagar todo o peço por inteiro, logo que apresentar a sexta parte dele, será o senhor obrigado a recebê-la, e lhe dará um dia livre na semana, e assim à proporção mais dias quando for recebendo as outras sextas partes até o valor total.

- Artigo 10. Todos os homens de cor forros, que não tiverem ofício ou modo certo de vida, receberão do Estado uma pequena sesmaria de terra para cultivarem, e receberão, outrossim, dele os socorros necessários para se estabelecerem, cujo valor irão pagando com o andar do tempo.

- Artigo 16. Antes da idade de doze anos não deverão os escravos ser empregados em trabalhos insalubres e demasiados; e o Conselho [o Conselho Superior Conservador dos Escravos, proposto no mesmo projeto] vigiará sobre a execução deste artigo para o bem do Estado e dos mesmos senhores.

- Artigo 17. Igualmente os conselhos conservadores determinarão em cada província, segundo a natureza dos trabalhos, as horas de trabalho, e o sustento e o vestuário dos escravos.

- Artigo 31. Para vigiar na estrita execução da lei e para se promover por todos os modos possíveis o bom tratamento, morigeração e emancipação sucessiva dos escravos, haverá na capital de cada província um Conselho Superior Conservador dos Escravos.

(NABUCO, Grifos no original e nosso)

O abolicionismo motiva a elaboração e a elucubração em torno de uma série de possíveis "políticas públicas" - se se pode usar o termo àquela época -, documentadas, por exemplo, em artigo que Roger Bastide, à época professor na Universidade de São Paulo, fez publicar na Revista Mexicana de Sociologia, em 1946, sob o título "El Positivismo Brasileño y la Incorporación del Proletariado de Color a la Civilización Occidental". De acordo com Bastide, 
os positivistas não consideravam a abolição senão como um ponto de partida da "questão social a resolver":

O problema essencial o colocara Comte: a incorporação do proletariado à civilização ocidental. Para Comte, o proletariado estava apenas "acampado" (campé) em nossa civilização, e não formava todavia parte integrante dela: sem domicílio fixo, levado de uma cidade a outra pelas exigências da indústria e das crises; sem infância, porque a mãe trabalhando na fábrica não pode educar seus filhos e lhes dar essa cultura do coração que é a parte essencial da educação; sem adolescência, porque obrigado a trabalhar, sem se instruir desde a idade mais jovem; com o hospital como único recurso contra a enfermidade; o asilo, como único recurso contra a velhice e finalmente, a mesa de refeitório e a fossa comum. Só que este problema se complicava no Brasil com a existência da escravidão. Era mister, por consequência, romper com esta anomalia antes de tudo. Havendo desaparecido, a tarefa não obstante não estava acabada, e o grande mérito dos positivistas foi haver visto isso com clareza, inclusive antes de que o abolicionismo fosse um fato realizado. Trabalharam desde o começo por enquadrar a abolição em toda uma série de medidas destinadas a situar o futuro liberto na sociedade nova, em poucas palavras, trabalharam por reorganizar "a pátria brasileira" (BASTIDE, 1946)

É interessante abrir um parêntese ver que a referência a uma "questão social" e seu rebatimento sobre o ciclo de vida da pessoa - infância, maturidade, velhice - é feita no contexto de construção daquilo que se chamaria hoje de uma política pública. Em contraste, as leis que se baixaram à época, como a Lei do Ventre Livre (1871) e a Lei dos Sexagenários (1885) são vistas como expedientes cruéis de prolongar e não mitigar a exploração e o sofrimento dos sujeitos a que se referiam. Segundo Samuel Vida,

Em 28 de setembro de 1871, a Lei do Ventre Livre declarava livre todo nascituro, mas previa a obrigação dos mesmos servirem aos escravocratas até atingirem a maioridade (21 anos), institucionalizando o sistema de exploração do trabalho infantojuvenil. Reservava, ainda, a opção de entrega dos menores ao Estado, ao completarem 08 anos, mediante uma indenização, para a criação em estabelecimentos apropriados. Identifica-se, aqui, 0 surgimento das primeiras versões das Febem's. Por fim, não é demais constatar que entre a Lei do Ventre Livre e a Abolição transcorreram apenas 17 anos, 0 que sugere as limitadas consequências práticas de tal medida.

Na mesma direção aponta a Lei dos Sexagenários, editada em 28 de setembro de 1885. Poucos escravizados chegavam aos sessenta anos, diante das agruras e brutalidades do escravismo. Ainda assim, a referida lei previa um regime de trabalho gratuito para o exproprietário durante cinco anos, além de limitações concernentes ao direito de locomoção. Convém, também, registrar o fato de que a Lei do Sexagenário institui um fundo de financiamento da imigração europeia, em detrimento de qualquer política compensatória para os recém-libertos. (VIDA, 2005, p.85) 
A menção ao financiamento da imigração europeia mostra que o Estado já tomara as decisões fundamentais em detrimento de todo o debate acerca da incorporação do "proletariado de cor", que mobilizava a imaginação militante, civilizadora, dos positivistas. Segundo Bastide, em 1880, o Centro Positivista do Brasil propunha as seguintes medidas:

$\checkmark$ Supressão imediata da escravidão.

$\checkmark$ Ligar à terra o ex-trabalhador cativo sob a direção de seus respectivos chefes atuais;

$\checkmark$ Supressão de castigos corporais e de toda legislação especial;

$\checkmark$ Constituição de um regime moral mediante a adoção sistemática da monogamia.

$\checkmark$ Fixação do número de horas de trabalho por dia e estabelecimento de um dia de descanso por semana.

$\checkmark$ Supressão do regime de internação pela generalização da vida da família.

$\checkmark$ Criação de escolas rurais nos centros agrícola, custeadas pelos grandes proprietários rurais.

$\checkmark$ Dedução de uma parte de uma parte dos rendimentos para 0 estabelecimento de um salário justo.

A propósito do segundo ponto, Bastide faz interessante digressão acerca de como os positivistas encaravam doutrinariamente a possibilidade de uma reforma agrária:

[...] não teria sido preferível dividir os latifúndios em pequenas propriedades que se entregariam aos antigos escravos? Não se opinava que o mal que sofria o Brasil se originava em seu regime de grande propriedade e de monocultura, resultante daquela? Este projeto de fragmentação da terra não poderia inclusive se justificar historicamente pelo exemplo da Europa: não conheceu este Continente um procedimento análogo em sua luta contra a aristocracia? Porém, Augusto Comte havia demonstrada e, assinalemos, antes que Karl Marx, que a lei da sociedade atual era a acumulação progressista das riquezas em mãos de uns quantos proprietários, em consequência não se pode lutar contra o determinismo sociológico e dar passos em direção a um passado em agonia. Os positivistas não se cansam de repetir que a pequena propriedade criou uma pequena burguesia, 
"egoísta, mesquinha", que se interpõe entre o rico e o pobre e impede que se estabeleça toda relação normal entre eles. Já Comte pusera os russos de sobreaviso acerca desta perigosa imitação do passado no momento em que Nicolau II promulgava a extinção da servidão. Teixeira [Mende] deixará, em consequência, os antigos escravos sobre as terras que trabalhavam em outro tempo e os subordinará ao patriciado (BASTIDE, 1946).

O abolicionismo não foi uma corrente endógena de pensamento. Suas maiores referências de organização provinham da campanha abolicionista travada na Inglaterra - a grande potência mundial - entre 1787 e 1807 - e por isso pairou sobre ele a pecha de ser inclusive "antinacional".

Aos poucos, porém permitiu o amálgama de muitas forças de interesses divergentes, Desse modo, não se deve confundir o abolicionismo como um movimento exclusivamente a favor dos negros.

Coligidas em livro praticamente ao mesmo tempo que 0 mencionado livro de Nabuco, e talvez superior em informações, nas Cartas do Solitário, de autoria de Aureliano Cândido Tavares Bastos, publicadas em 1861, lê-se:

Para mim, o emigrante europeu devia e deve de ser o alvo de nossas ambições, como o africano o objeto de nossas antipatias. Além de tudo, eu descubro no desenvolvimento da imigração um grande resultado, que porventura poderia fixar ou mudar a face política deste país. O emigrante é, cedo ou tarde, o pequeno proprietário. E na pequena propriedade está o espírito de conservação e liberdade, que caracteriza os habitantes dos campos em todos os países.

A citação mostra como muitas correntes que se agregaram e mesmo anteciparam o pensamento de Nabuco, imputaram ao negro consequências que eram da escravidão, coisa fácil de fazer num século em que o racismo começava a se tornar "científico", como vimos em algumas citações do capítulo anterior. Mais que isso, mostra como o abolicionismo tinha o potencial de incorporar setores da sociedade que viram na abolição a oportunidade de fazer uma política de construção de uma nação que coibiria a expansão, a expressão, a manutenção e mesmo a sobrevivência da população negra. 
Deve-se ressaltar a ideologia do branqueamento como teoria suplementar aos modelos explicativos da singularidade do racismo brasileiro. Alguns autores, como Oliveira Viana (1922), afirmavam a ideologia do branqueamento como uma política deliberada do governo.

Dessa forma, o movimento denominado de eugenista, também identificado como higienista, irá constituir-se em uma teoria para uma "política" nacional de embranquecimento, tendo sido inspirado pelo ensaio do então "conselheiro" Joseph Arthur de Gobineau, intitulado "Essai sur l'inégalité des races humaines" (Ensaio sobre a desigualdade das raças humanas).

Vários autores e intelectuais ligados ao século XIX e início do século XX promoveram e protagonizaram a efervescência do prestígio dessas teorias, como Nina Rodrigues, José de Alencar, Euclides da Cunha, Gilberto Freire, Monteiro Lobato, Joaquim Nabuco, Sílvio Romero, Manoel Bomfim, dentre outros, todos empenhados em decifrar "o enigma das raças". ${ }^{5}$

As formulações do Conde de Gobineau (1816-1882) profetizaram com pessimismo a decadência da civilização como resultado da mistura de sangues e do abastardamento das "raças superiores e puras". A incapacidade das raças não brancas para a civilização não teria como ser corrigida pela educação. Para ele, a mestiçagem poderia elevar intelectualmente as raças inferiores, com o inconveniente de rebaixar as etnias superiores participantes da mistura. Gobineau Identificava a civilização à raça branca. E era descrente e pessimista quanto ao futuro dos países latino-americanos, onde os cruzamentos raciais e a degradação dos europeus trariam a decadência: "A América do Sul, corrompida em seu sangue crioulo, não tem meios de evitar a queda de seus mestiços de todas as variedades e classes."

Gobineau esteve no Brasil em 1869 e 1870, a convite de Dom Pedro II (leitor contumaz de suas obras), na qualidade de representante do governo francês, como nos fala Ventura no livro Estilo Tropical, "estando em terra brasilis, Gobineau revelou horror à população brasileira, a qual chamou de multidão de macacos, composta de mulatos que apenas comprovariam suas

${ }^{5}$ Ao definir como o enigma das raças, o autor pretende explicitar que a temática racial sempre foi apresentada como uma "não-questão", apenas um problema pontual e de caráter interpessoal. Todavia na formulação das estratégicas políticas ela aparece como um dos fatores mais relevantes a ser considerados. 
idéias pessimistas sobre a degeneração dos mestiços e a decadência da civilização".

"Prata da casa", José de Alencar (1829-1877) também pretendeu refazer o traçado da construção da nação brasileira, baseando-se na idealização dos tipos formadores que, como heróis, possuiriam qualidades superiores aos mortais comuns. José de Alencar retratou detalhadamente 0 sertanejo, o gaúcho, o índio, o bandeirante, além do colonizador branco. Neste cenário, o negro não estava contemplado.

Enquanto deputado, Alencar colocou-se contra a Lei do Ventre Livre que faria livres os descendentes de escravizados, após anos de servidão, como vimos. O consagrado romancista julgava a escravidão um fato social necessário, cuja extinção deveria se dar de forma muito gradual, de acordo com a evolução natural da sociedade brasileira, pois, de outra forma, a agricultura estaria ameaçada, bem como a estabilidade política do Império.

Em crítica feita a uma peça de José de Alencar, a partir de um debate famoso nos periódicos da época, Joaquim Nabuco (1849-1910) criticou a contradição entre o deputado Alencar, que era a favor da escravidão, e 0 literato Alencar, que traduzia personagens escravas com tratamento sentimental em suas peças teatrais.

O próprio Nabuco também é contraditório ao lutar pelo fim da escravidão e ao considerar a arte, o domínio político e cultural como expressão idealizada da sociedade branca, rejeitando o realismo de Alencar ao retratar a temática da escravidão no teatro.

Em síntese, Nabuco punha o dedo na ferida para escondê-la. Daí sua completa rejeição ao teatro exposto por Alencar, por escancarar no palco da corte a realidade social brasileira em completo desacordo com os padrões europeus.

Referência clássica da elite intelectual brasileira à época, Nabuco não concebia as possibilidades de alto desenvolvimento humanista da paisagem sul-americana. Para ele: "O espírito humano que é só um e terrivelmente centralista, está do outro lado do Atlântico." (NABUCO, 1957, p.48).

Contemporâneo de Nabuco, Silvio Romero (1851 - 1914) elaborou uma teoria da mestiçagem e do branqueamento que partia de pressupostos racistas e evolucionistas. Romero postulava a existência de diferenças étnicas 
inatas e a existência de uma lei de concorrência vital e do predomínio do mais apto, prevendo que o elemento branco seria vitorioso na luta entre as raças.

Silvio Romero atribuiu à atuação diferenciadora do mestiço a criação do folclore brasileiro e tomou a literatura como expressão da raça e do povo, passando a considerar a mestiçagem como fator de diferenciação nacional e de critério de valor literário.

No entanto, em seus estudos construiu uma hierarquização da participação e contribuição cultural das raças, onde o negro é apresentado como superior ao indígena e, o branco, como o mais evoluído dos três.

Sua consciência abolicionista e seu discurso etnológico traduzem as contradições pelas quais passaram também outros pensadores de sua época:

[...] libertemos os negros: por que os devemos considerar os desafortunados que nos ajudaram a ter fortuna; os cativos que nos auxiliaram na conquista da liberdade. Os ignorantes que nos facilitaram a posse da civilização, e hoje nos oferecem o ensejo de praticarmos um ato nobre; a emancipação dos escravos." (Silvio Romero apud VENTURA, 1991, p.47)

Também Nina Rodrigues (1862-1906) proclamou "evidência científica" da inferioridade do negro brasileiro. Defendia não haver discrepância entre ter a consciência abolicionista e abraçar a etnologia racista, pois considerava que a defesa da abolição não implicava abandonar as teorias de desigualdades étnicas, ao contrário, vinha reforçá-las. As populações não brancas eram vistas como obstaculizadoras à universalização dos princípios liberais, pois estas

[...] desmentiriam princípios fundamentais ao liberalismo, como o livre arbítrio e a capacidade de discernimento, sendo obstáculo à implantação de sistema político de bases democráticas e representativas." (VENTURA, 1991, p. 53)

Nina Rodrigues propôs a criação de uma legislação penal para o Brasil dividida em códigos distintos, um para cada raça, pois as mesmas se encontrariam em estágios evolutivos também distintos. Considerava que 0 negro, o índio e o mestiço deveriam ter suas penas nulas ou atenuadas por se apresentarem não só tendências à loucura e à paranoia, mas, também, um alto grau de tendência à criminalidade, "devido à sobrevivência psíquica de caracteres de uma fase evolutiva mais atrasada". 
O alto grau de criminalidade apresentado pelo mestiço seria em virtude da degeneração resultante do cruzamento das raças díspares e do ressurgimento de traços ancestrais.

Para Euclides da Cunha (1866-1909), o sertanejo, embora etnicamente misturado, havia se constituído longe do litoral e, em decorrência disso, não teria vivenciado determinadas circunstâncias históricas as quais poderiam ter desvirtuado sua formação.

O autor de Os Sertões estabeleceu um contraste entre o rude sertanejo (de origem euro-indígena, para ele), o degenerado mulato e o fraco e subserviente negro das plantações do litoral. Cunha "aparentemente esqueceu que, conforme Freyre mostrou, muitos dos sertanejos a quem ele (Cunha) admirava teriam tido igual descendência africana no estado da Bahia". (BROOKSHAW, 1983, p. 59-60).

O mestiço do sertão teria vantagem sobre o mulato do litoral devido ao isolamento histórico e à ausência de componentes africanos, tornando mais estável sua evolução racial e cultural.

De acordo com Monteiro Lobato (1882 - 1904), "Não sabemos o que somos. Há tanta escora e espeque e amarrilho de cipó na nossa estrutura social, que ninguém consegue ver claro a forma do nosso edifício. Parece república e não é. Parece democracia e não é. Parece país não é. Parece que está vivo e não está",

Fazendeiro, alinhando com as perspectivas do desenvolvimento econômico, Monteiro Lobato teve importante participação na configuração do pensamento social dominante na passagem do século XIX para o século XX. Ele via na presença do caboclo e do negro a degenerescência racial influenciando a identidade nacional.

Adepto das teorias científicas europeias, cujo determinismo biológico sustentava a ideia de degenerescência racial a partir do negro e do caboclo nacional, Lobato sedimentou um padrão literário que primou pelos valores eugênicos. Sua grande contribuição para o pensamento social nacional, através da marcante literatura infantil, é também sua obra mais rica na conformação do racismo brasileiro.

Voz discordante das doutrinas racistas da época, Manoel Bomfim (1868-1932) realizou análise cuidadosa das causas históricas para entender o atraso relativo do Brasil e da América Latina. Bomfim examinou a história e o 
caráter nacional a partir do caráter ibérico e ao longo do curso da própria colonização. A mentalidade de ficar rico depressa e a ausência de organização social figuram entre as possíveis causas do atraso brasileiro.

A armação ideológica da existência de etnias inferiores era considerada por Bomfim como uma justificativa para a formação de um novo imperialismo. Aqui, ele atacava a subalternização do pensamento social da maioria dos intelectuais de sua época, por conta da adesão intelectual às ideias estruturais do racismo científico.

Bomfim criticou em especial a política populacional brasileira, por haver abandonado os ex-escravizados depois da abolição. Em suas ácidas críticas aos arranjos institucionais e aos debates que antecederam a esse momento, ele escreveu que a

[...] abolição falhou, tanto nas suas exigências políticas, como nos outros motivos sociais. Seria consequência lógica do abolicionismo vitorioso a organização do trabalho inteligente e livre; preparo do trabalhador, completado na sua educação política. Leis sociais da proteção do operariado contra a exploração dos patrões; o seu direito de organização sindical e de greve; a garantia de boa higiene - no esforço e na disposição de locais; organização de seguros acidentes e velhice . . o indispensável, em suma, para que o proletário não seja um espoliado; o necessário para que a produção não seja uma exploração cruel dos que realmente trabalham. Nada disto se fez; aboliu-se legalmente o cativeiro para que os cativos de ontem, e todos os proletários, ficassem à mercê da ganancia patronal, economicamente mais escravos hoje do que era antes. Não se pedia que o abolicionismo resolvesse a inteira questão social; mas, para que a vitória de 13 de maio fosse a redenção efetiva do trabalho, havia que remir efetivamente o Trabalhador. (BOMFIM, 1996, p.366)

É com Mário de Andrade (1893-1945) que a representação da origem do povo brasileiro começa a se realizar por outros parâmetros. Grande líder do movimento modernista brasileiro, em Andrade uma nova atitude frente ao afrobrasileiro e ao indígena passa a ganhar concretude. Em Macunaíma, ele integra o mito do indígena ao mito africano para explicar a formação do povo brasileiro. Segundo o próprio Mário, "Macunaíma é uma alegoria à cultura brasileira e seu caráter "inacabado" (BERND, 1990; p.94).

Também pensador modernista, a Gilberto Freyre (1900-1987), como vimos, atribuiu-se a autoria intelectual do mito da democracia racial. Em Casa 
Grande e Senzala, sua obra referencial, ele aponta a miscigenação como fator explicativo da suposta tolerância racial vigente na sociedade brasileira.

Sua grande contribuição foi ter mostrado que brancos, negros e índios tiveram contribuições positivas na cultura brasileira, a partir de um ideário harmonioso cujos conflitos não se assemelhavam a realidade norte americana.

Talvez o mais controverso e criticado pensador brasileiro, no tocante a questão racial, Freyre incorpora intensamente o julgamento racista anglo-norteamericano e faz comentários sobre marinheiros brasileiros no Brooklin, em Nova York, dizendo que são feios porque são racialmente miscigenados e citando o caráter vira-lata da população brasileira (FREYRE, 2000; RIBEIRO, 1997; p.85).

As colaborações de todos esses intelectuais foram decisivas para uma construção de base teórica para o pensamento social brasileiro em torno de uma identidade nacional. $O$ aprofundamento desses estudos teve prosseguimento, pois o fenômeno do sistema brasileiro das relações raciais suscitou um conjunto de pesquisas e embates importantes para uma compreensão mais adequada da questão racial.

A questão central, que retoma a profundidade do debate, é formulada por Kabengele Munanga:

De que maneira conceber a construção de uma nação e de uma identidade nacional, a partir de novas categorias de cidadãos exescravizados negros? Como transformá-los em elementos constituintes da nacionalidade e da identidade brasileira quando a estrutura mental herdada do passado, que os considerava apenas como coisas e força de trabalho, ainda não havia mudado? (MUNANGA, 1999; $p$ 38)

\section{DAS CONSTITUIÇÕES APÓS-ABOLIÇÃO À FRESTA DA} CONSTITUIÇÃO DE 1988

A primeira constituição após a abolição, promulgada em 24 de fevereiro de 1891, estabeleceu no Art. $72, \S 2^{\circ}$ : "Todos são iguais perante a lei", adotou a República como forma federativa de Estado, transformou as províncias do império em estados federados, estabeleceu a tripartição dos 
poderes por inspiração da doutrina de Montesquieu, instituiu o estado não confessional - de forte caráter positivista.

No contexto da questão racial, "essa constituição representou a ampliação dos direitos civis e políticos, mas caracterizou uma barreira legal no impedimento ao acesso da população negra às urnas - ao impor a alfabetização como requisito para o direito de sufrágio em um país recém-saído do escravismo", além de excluir outros segmentos, a exemplo das mulheres." (SILVA, p).

Após a chamada Revolução de 1930, o país conheceu duas constituições. A primeira, promulgada em 16 de julho de 1934, estabeleceu uma ruptura com a concepção liberal de Estado. O texto demonstrava grande preocupação e compromisso com a questão social, traduzidas pelas disparidades existentes entre os setores produtivos. No entanto, estabelecia um paradoxo ao repudiar a discriminação racial - Art.113.1. "Todos são iguaes perante a lei. Não haverá privilégios, nem distinções, por motivo de nascimento, sexo, raça, profissões próprias ou dos Paes, classe social, riqueza, crenças religiosas ou ideias políticas." - ao mesmo tempo em que prescrevia uma política educacional baseada nos pressupostos eugênicos, de acordo com o que prescreviam o Art. 121, $\S 6^{\circ}$, "A entrada de immigrantes no território nacional soffrerá as restrições necessárias à garantia da integração ethinica e capacidade physica e civil do immigrante" e o Art. 138, "Incumbe à união, aos Estados e aos Municípios, nos termos das leis respectivas: estimular a educação eugênica.

A terceira constituição republicana brasileira foi outorgada em 10 de novembro de 1937 por Getúlio Vargas. E foi denominada "polaca" por conter forte teor antidemocrático, inspirada na constituição ditatorial da Polônia de 1935. Ao se considerar o caráter totalitarista do governo Vargas, a supressão das garantias estava vinculada ao modelo constitucional inspirado em ideais eurocêntricos.

Enunciar no Art.122.2. "Todos são iguais perante a lei." passava por exercício puramente formal, pois não havia uma lei especifica que controlasse a manifestação racista por uma lei infraconstitucional, em vista de que a manifestação de racismo é cotidiana. 
Nove anos depois, em 18 de setembro de 1946, a quarta constituição republicana proveio da redemocratização do país, precedida da queda de Getúlio Vargas. Pecando pela pouca efetividade (eficácia social), passou por reformas profundas para não cair no descrédito. O Art.141, $1^{\circ}$ dizia: "Todos são iguais perante a lei." E seu $\S 5^{\circ}$ dispunha: "não será tolerada propaganda de preconceito de raça ou de classe".

A quinta constituição republicana, promulgada em 24 de janeiro de 1967, sob forte orientação militar, vai buscar a centralidade por meio de medidas de supressão de direitos e de interferências nos Estados e municípios, estabelecendo uma forte preocupação com a segurança nacional. Seu Art.150, $\S 1^{\circ}$. estabelecia: "Todos são iguais perante a lei, sem distinção de sexo, raça, trabalho, credo religioso e convicções políticas. O preconceito de raça será punido pela lei." E ○ Art. 158, inciso III, determinava a proibição de diferenciação de salários, e de critérios de admissão por motivo de sexo, cor e estado civil.

Dois anos depois, a Emenda Constitucional №1/69 a Constituição de 1967- imposta por uma junta militar em 17 de outubro de 1969, respondia ao recrudescimento da ditadura e destacava papel das forças armadas na defesa nacional, com supressão dos direitos civis e políticos, supressão do exercício do poder constituinte originário.

Segundo o Art.153,§1ำ, "Todos são iguais perante a lei, sem distinção de sexo, raça, trabalho, credo religioso e convicções políticas. $O$ preconceito de raça será punido pela lei."

Por fim, a Constituição de 1988 foi promulgada a 05 de outubro de 1988, em período considerado como o do ressurgimento das esperanças e florescimento das expectativas da população. O objetivo central era implantar um Estado Democrático de Direito com base na justiça social. Art. 5ํㅡ, XLII, dispõe que "a prática de racismo constitui crime inafiançável e imprescritível, sujeito a pena de reclusão, nos termos da lei."

De acordo com Samuel Vida,

A constitucionalização da perspectiva anti-racista na Constituição Federal de 1988 não apenas autoriza a adoção de políticas afirmativas de caráter compensatório e promocional para a população negra, como efetivamente, impõe tais iniciativas como dever do Estado, no cumprimento dos objetivos constitutivos da República. Estabelece, também, a inclusão do recorte racial 
nas políticas públicas desenvolvidas pelo Estado, como decorrência do caráter multicultural e pluriétnico da formação social brasileira. (VIDA, 2005, p.97)

\section{CICLOS CONSTITUCIONAIS E INTEGRAÇÃO DA POPULAÇÃO NEGRA}

Este trabalho começou justamente evocando as perspectivas abertas pela Constituição de 1988, saudada como um marco para a elaboração de políticas públicas para a população negra. Os sucessivos ciclos constitucionais sempre representaram tentativas de "constituição de uma nação" ou de "reconstituição de uma nação", sempre foram uma oportunidade de novo recomeço.

O ano de 1988 correspondia também ao centenário da abolição, podemos até dizer centenário da Abolição-República, em que o início da era do mercado de trabalho livre assinalava a oportunidade de um novo recomeço para o Brasil. Escrevemos "um novo recomeço" por que o primeiro - a Independência política do Brasil - deu-se em um processo de construção nacional limitado justamente pela manutenção das estruturas que o mundo da colonização estabelecera (a agricultura fundada no trabalho escravo).

O "recomeço republicano", com o início da era do trabalho livre, também foi detido pela exclusão civilizacional dos negros, fundada ideologicamente no "racismo científico", no branqueamento, e, praticamente, assentadas nas políticas de incentivo à imigração europeia e de contenção das possibilidades negras de afirmação social.

O caducamento político desse "recomeço republicano", iniciado em 1922 e culminado em 1930, não impediu que a chamada "República Velha" ainda corresponda ao mais longo período de eleições sem interrupção que nós conhecemos (1894, 1898, 1902, 1906, 1910, 1914, 1918, 1922, 1926, 1930), superior ao momento presente $(1989,1994,1998,2002,2006,2010,2014)$, aberto pela Constituinte de 1988.

Sempre houve referências para compreender as crises políticas do Brasil de um ponto de vista eurocêntrico, desprezando-se o peso que a não integração ou incorporação subordinada nela teve. Nesse ponto, vale lembrar 
que 1988 também foi marcado pela "anticomemoração da abolição", promovida pelo movimento negro, fator pelo qual muitos intelectuais saudaram os protestos como um marco para o fim do mito da democracia racial.

Pelo menos desde 2013, no marco das chamadas "jornadas de junho", fala-se em nova constituinte para estabelecer uma outra constituição. Poder-se indagar, do ponto de vista deste trabalho qual o peso teve este último ciclo constitucional, ao incorporar/integrar protagonistas negros no debate, para compor parte da crise que pede nova constituição - seja positivamente, por conta da incorporação/integração de novos protagonistas que requerem espaço; seja negativamente, por conta da ojeriza à incorporação/integração de novos protagonistas que interferem em espaços "imaculados" racialmente.

Nos próximos capítulos, procuraremos caracterizar a questão inconclusa das políticas afirmativas e suas consequentes estratégias adotadas, quer no sistema de cotas, quer nas perspectivas de mecanismos de gestão (transversalidade, dotação orçamentária, lugar da política racial, expressão discricionária dos gestores quanto ao papel central da política).

\section{CAPÍTULO 3 - PERIODIZAÇÃO DAS POLÍTICAS RACIAIS NO BRASIL CONTEMPORÂNEO}

$\mathrm{Na}$ curta história republicana de preocupação com a elaboração de políticas raciais no Brasil, é possível distinguir subperíodos, a partir da identificação de dinâmicas e características próprias. Na Figura 1, a seguir, eles podem ser visualizados como níveis ou camadas temporais dispostos, grosso modo, em torno das últimas quatro décadas.

Neste capítulo, envidamos um esforço de recuperação de questões, atores e relações de força cujas transformações fundamentam a suposição de que houve mudanças temporais neste curto espaço de tempo histórico, cuja direção (de avanço, de retrocesso, à esquerda ou à direita) e cujo ritmo (moderado, acelerado) cabe-nos pesar e pensar politicamente. 


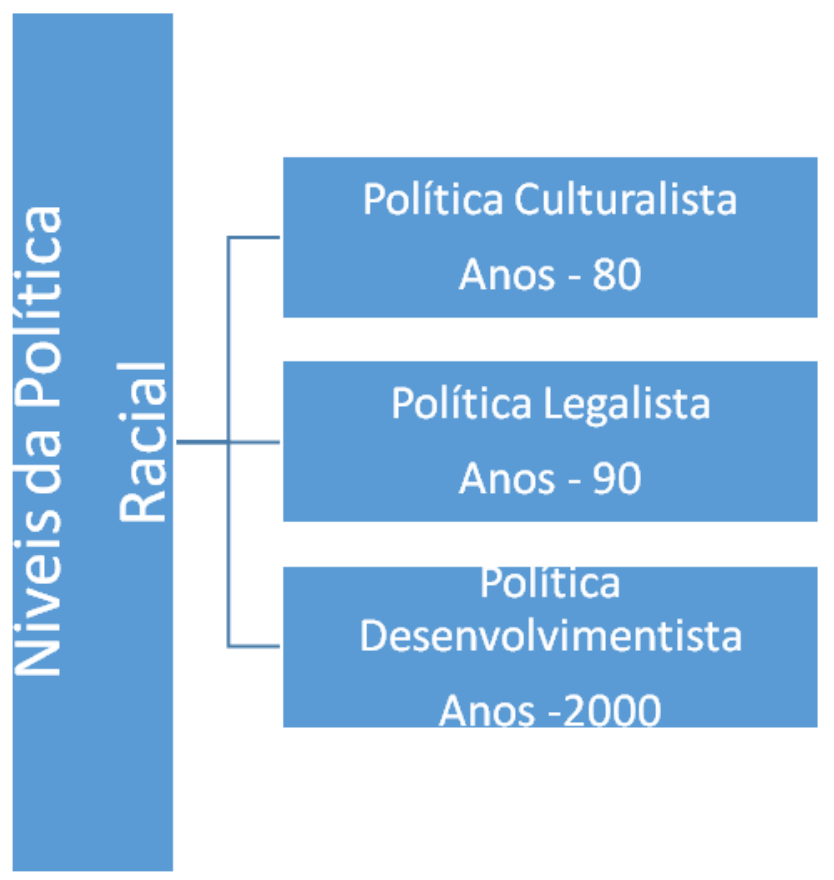

POLÍTICA CULTURALISTA - ANOS 1980

Esse período é um marco referencial das profundas mudanças ocorridas nas perspectivas sociais, políticas e institucionais. O intenso movimento verificado na luta pela abertura política, iniciada na década de 1970 , irá marcar decisivamente o fim de uma era autoritária e a transição para um momento de efervescência política em que a mobilização e participação política dos diversos movimentos sociais passam a ter papel importante na reestruturação das administrações públicas.

É nesse cenário, que as organizações negras marcam posicionamento nas diversas instâncias do processo democrático nacional, visando integrar o amplo arco para a ampliação democrática.

O que denominamos de política culturalista marca um período pautado por uma forte onda em torno dos chamados debates multiculturais, que trouxe a questão da pluralidade cultural, inserindo de maneira significativa o direito das chamadas minorias na agenda política. A representação desses grupos passa 
a compor o amplo espectro reunido em torno das discussões sobre identidade nacional e reconhecimento político-social.

$\mathrm{Na}$ configuração desses debates no Brasil, esse clima sinalizou uma perspectiva inicial de reconhecimento da identidade negra com base nos valores étnicos e um pertencimento comum. As principais reinvindicações eram expressas na busca de reconhecimento político e acesso aos direitos civis bem como na valorização das diferenças.

Em síntese, o debate ensejou ao Estado brasileiro um desafio cuja expressão maior era se descolar do modelo hegemônico de nação baseado no pensamento único europeu e contemplar as diversas composições étnicoraciais. A década de 1980 era marcada por uma conjuntura muito favorável à discussão política do papel do negro na sociedade. Esses fatores foram determinantes para a inserção de uma perspectiva de incorporação simbólica dos marcadores raciais enquanto características da nação.

A especificidade da realidade social brasileira, nos termos dessa incorporação, por certo levou a uma indispensável arquitetura dos sentidos da ideologia política e a natureza desigual das relações sociais. Ao negar as especificidades decorrentes do passado autoritário e escravistas, as regulações políticas seguiram na direção de uma modernização das forças produtivas e do desenvolvimento econômico.

Desta forma, o ponto central para esse estudo segue no questionamento de como essa política engendrada nos 1980, com seus novos padrões econômicos com base no comércio, na produção e no empreendimento poderiam efetivar uma participação social do negro.

Alguns fatores em diversos contextos, quer nacionais quer internacionais, geravam uma repercussão capaz de mobilizar as organizações dos movimentos negros brasileiros.

No cenário internacional, havia as lutas pelos direitos civis de grupos étnicos na América Latina, pela autodeterminação dos povos, as lutas anticolonialistas dos países lusófonos (Angola, Moçambique, Guiné Bissau), além de fatos internacionais que colaboravam para uma maior solidificação das legislações internacionais, a exemplo da instituição do dia 21 de março como Dia Internacional pela eliminação da Discriminação Racial, em memória do massacre de Shaperville, em 1960, na África do Sul. 
Dentro desse contexto, é importante destacar o cenário nacional, em que tínhamos um conjunto de reverberações quanto a expressões de luta na afirmação de uma identidade negra. O bloco afro llê Aiyê, em 1974, foi um dos primeiros blocos carnavalescos a dar visibilidade à história negra no Brasil, com destaque a sua principal característica de ser um bloco negro onde a presença branca era vedada em repúdio à prática discriminatória de outros blocos e agremiações carnavalescas.

Outro importante fato foi a criação do Instituto de Pesquisas e Culturas Negras (IPCN), no Rio de Janeiro, em 1976. Cujo objetivo era de construir um espaço de estudos e pesquisas em torno da questão racial.

E, como marco decisivo, em 1978, temos a fundação do Movimento Negro Unificado contra a Discriminação Racial, uma das maiores expressões das lutas antirracistas à época. O surgimento desse movimento social organizado protagonizou uma nova etapa quanto a denúncias das práticas discriminatórias existentes no país.

Como resposta a esse momento tão intenso quanto ao debate racial, é criada a Fundação Cultural Palmares (1987), órgão governamental com o objetivo de atender as demandas oriundas da população negra no país.

Entre o discurso do movimento negro e as ações preconizadas pelo governo há que considerar uma distinção entre o que é demanda e o que é resposta. Entre as consequências do modelo econômico e as manifestações ilustrativas de uma cultura "exótica" (vista de fora), optou-se por enfatizar as contribuições culturais em detrimento das políticas infraestruturais relacionadas à questão econômica e política.

A própria definição de Fundação Cultural Palmares desloca o conceito de cultura a algo factual, sem conexão direta com os aspectos econômicos e sociais ${ }^{6}$. Com efeito, essas primeiras manifestações expressas na política de Estado revelaram uma escolha por valorizar a identidade e memória em

${ }^{6}$ A definição e denominação de Fundação Cultural Palmares, em nosso entendimento, revela uma característica marcante em torno da questão racial no Brasil. Ao ser instituída a referida fundação passa a ter um foco muito determinado: o cultural, nessa perspectiva, volta- se para aspectos mais, digamos assim, aceitáveis na cultura negra, tais como capoeira, congadas, manifestações sincréticas do folclore brasileiro, dentre outras, em contraponto a linhas limitadoras de classe e raça, ao preconceito racial e ao racismo. Com isso, há o reforço de uma hegemonia teórica em torno de formulações e entendimento das relações raciais brasileiras. 
detrimento do legado social e político que a questão racial enseja na conformação social do país.

O governo manifesta uma percepção quanto ao "problema racial" e procura expressá-la através de políticas pontuais na perspectiva culturalista. $\mathrm{Na}$ restrição da política estatal a um mero campo cultural, destaca-se que a Fundação Cultural Palmares foi vinculada ao Ministério da Cultura, órgão de menor expressividade orçamentária e política no cenário dos Ministérios

O discurso político segue a linha tradicional em que a dimensão paternalista em consonância com uma apreciação simbólica do legado africano sinaliza um discurso retórico sem considerar o caráter substancial de expressiva parcela da população negra vivendo em condições de extrema pobreza. As ações e os atos adotados não revelamte uma visão mobilizadora capaz de mudar a realidade dessa população.

No entanto, paradoxalmente, o principal desafio dos anos 1980 era traduzir a abertura democrática em um modelo de gestão capaz de intensificar a mobilização social, bem como criar as bases para o estabelecimento da nova ordem democrática.

Esse era o momento em que os novos padrões de sociabilidade exigiam formas diferentes na configuração de políticas e gestão que tivessem como eixo basilar o reconhecimento do papel central das políticas sociais em consonância com as demandas sociais, bem como o efetivo reconhecimento dos direitos sociais.

Não obstante esse contexto marcado pela ampliação da participação de diferentes segmentos sociais, a base governamental acenava com parcos espaços de integração dos anseios populares, sinalizando com respostas pontuais e fragmentadas. No tocante a questão racial, o Governo adotou a estratégia de incorporar algumas ações a partir de um plano de revitalização da cultura negra através dos símbolos mais visíveis dessa cultura, tendo como referência os valores centrais da resistência cultural negra e suas principais manifestações sincréticas e religiosas já incorporadas pelo conjunto da sociedade nacional.

As diretrizes e os objetivos ficaram restritos a pontuais sinalizações quanto ao enfrentamento da discriminação racial e outras ações priorizaram o fomento a manifestações culturais como legado simbólico de uma coletividade. 
O surgimento da Fundação Cultural Palmares ilustra essa expressão política. Esse órgão vinculado ao Ministério da Cultura teria a incumbência de tratar em nível nacional das questões relativas à valorização da cultura negra como expressão máxima do apreço do Estado Brasileiro.

Cabe lembrar que o governo Sarney, cujo marketing político estava assentado no lema de "cidadania e Justiça", procurava um descolamento das marcas do regime anterior. A questão racial teve ao menos no campo comunicacional de governo uma pauta baseada incorporação das denúncias do movimento negro em torna da discriminação racial, da luta pela igualdade de direitos e pela valorização da cultura.

As ações relativas à questão racial ficaram adstritas a ações pontuais junto ao Ministério da Cultura, ao Ministério da Justiça, através da Secretaria de Estado de Direitos Humanos com maior incidência, e ao Incra. Na temática específica de quilombos, por se tratar de ação consubstanciada na Constituição enquanto determinação formal para o reconhecimento das terras remanescentes de quilombo.

Para o conjunto da militância negra, havia uma convergência quanto as principais reivindicações pela preservação e valorização da cultura de matriz africana e pelo reconhecimento pleno de cidadania, o que implicava um consequente enfrentamento das desigualdades perpetradas pelo modelo capitalista aliado ao racismo estrutural da sociedade brasileira.

Dentro de um contexto ainda muito impregnado pelas mudanças decorrentes da abertura democrática, o clima de esperança serviu de blindagem as reais intenções do Governo, diante do antagonismo existente entre as políticas implementadas e a demanda por políticas efetivas para 0 enfrentamento do "problema racial", transformado de questão aparentemente tópica a questão nacional que requeria já naquela época decisão e escolhas quanto ao modelo de sociedade inclusiva.

\section{POLÍTICA LEGALISTA - ANOS 1990}

Em meio à efervescência política de rearticulação dos movimentos sociais, no anos 1990, o Movimento negro brasileiro, marcado por processos diversos de organização, passa a realizar encontros regionais de negros. De 
norte a sul do país, essa estratégia cumpria vários papéis importantes. De início, possibilitava uma maior aproximação dos negros e suas organizações pelo país; por fim, a construção de agendas comuns passava a ter novos referenciais até então não contemplados.

Tal inserção de questões novas se verificava de maneira muito interessante pelas representações religiosas, tanto de grupos cristãos como de grupos ligados a tradições de matriz africana (umbanda, candomblé e outras denominações).

Os diversos encontros realizados pelo país tiveram papel central na redefinição das estratégias para a consolidação da pauta racial. No entanto, é com a realização do I Encontro Nacional de Entidades Negras - I ENEN, realizado no período de 14 a 17 de Novembro de 1991, em São Paulo, que houve uma radiografia das diversas forças vinculadas às organizações negras.

\section{Tipologia das Organizações do Movimento Negro}

É importante a explicitação desse momento, por se tratar de um marco referencial das lutas antirracistas, pois até aquele momento não se tinha a dimensão do vasto número de organizações do movimento negro, assim definidas à época:

\section{a) Organizações de caráter nacional}

Tendo como objetivo central disseminar os processos organizacionais de luta antirracista, essas organizações tiveram um papel importante na consolidação de uma sistemática articulação dessa luta. Seu caráter nacional possibilitou o surgimento de outras bandeiras de luta vinculadas ao tema e sinalizou uma efetiva perspectiva de unidade na diversidade como pauta para as políticas públicas.

Nota-se que as duas principais vinculações dessas organizações foram concomitantemente a igreja católica e os partidos políticos de esquerda, a exemplo do MNU - Movimento Negro Unificado, corrente política com proximidades ao Partido dos Trabalhadores; UNEGRO - União dos Negros pela Igualdade, corrente política vinculada ao PCdoB; APNs - Agentes de 
Pastoral Negros, corrente vinculada a igreja católica a partir da Teologia da Libertação; e do Grupo União e Consciência Negra, corrente também vinculada a igreja católica.

b) Organizações de caráter estadual e municipal

Essas organizações, para além das organizações de caráter nacional, compunham-se de acordo com a incidência de população negra nos estados e municípios. Caracterizavam-se, sobretudo, pelas manifestações culturais negras, a exemplo das organizações que tinham como ponto forte as manifestações populares de grupos de congadas, reisados, maracatus e folguedos de grandes aglomerações, cujas raízes negras aglutinavam famílias, bairros e localidades. Com o processo de mobilização política, essas representações tiveram atuações que confirmavam uma necessidade de expressar suas demandas por reconhecimento e identidade.

c) Organizações religiosas de matriz africana

De caráter mais específico, essas organizações ligadas a umbanda e candomblé, em sua grande maioria e ao jongo (Rio de Janeiro), tiveram papel significado na denúncia das agressões sofridas por esse segmento na violação de direitos perpetrada pela intolerância religiosa sobretudo da parte de segmentos neopentecostais.

Com a realização do I ENEN, em meio aos debates, a pauta das populações religiosas foi discutida de maneira bastante incisiva, por não compor o conjunto das preocupações da maioria dos segmentos que tinha na luta de classe seu vetor central. O importante debate que daí decorreu suscitou o nascimento de uma organização denominada CENARAB - Centro Nacional de Articulação das Religiões Afro-Brasileira.

d) Organizações não governamentais - ONGs 
Esse período também foi marcado pela grande ênfase dada às organizações não governamentais e ao financiamento de processos organizativos internacionais. Nesse sentido, o movimento negro teve algumas organizações que se destacaram, como o Centro de Articulação das Populações Marginalizadas - CEAP/RJ, o qual teve seu marco inaugural ao denunciar o extermínio de jovens e crianças negras por grupos de milícias no Estado do Rio de Janeiro; o Instituto da Mulher Negra - GELEDES, dedicado a luta contra o racismo e o sexismo, uma organização específica de mulheres negras. Outras duas organizações com o mesmo formato relacionado a luta das mulheres negras, o Grupo FALA PRETA/SP e o Grupo CRIOULA/RJ, também marcaram e redefiniram diretrizes da luta antirracista.

Outro grupo atento às pautas nacionais e internacionais que definiu um campo de atuação significativo foi o Centro de Estudos das Relações do Trabalho e Desigualdades - CEERT. Essa organização teve nas denúncias do racismo no mundo do trabalho seu maior papel. Ao assumir os desdobramentos dessa denuncia deu corpo aos debates em torno da Convenção 111,7 que trata de combater as discriminações no mercado do trabalho. Sua atuação mobilizou o governo no enfrentamento das discriminações e desigualdades étnico-raciais no mundo do trabalho, impelindo-o à formulação de políticas públicas antirracistas.

Do I ENEN à Marcha Zumbi dos Palmares - rumo a reivindicações estruturais

O período que decorre da realização do I Encontro de Nacional de Entidades Negras (1991) até a eleição do FHC registra um crescimento exponencial das organizações do movimento negro, muito pelas exigências dos processos organizativos. A consolidação dos fóruns estaduais de entidades negras disseminad $\backslash$ pelo Brasil potencializou a magnitude das organizações negras em suas mais variadas vertentes, mas convergente em alguns pontos chaves - terra, saúde, trabalho, educação e combate ao extermínio de crianças e adolescentes.

${ }^{7}$ A Convenção 111 trata da discriminação no emprego e na profissão. Adotada em 25 de junho de 1958, entrou em vigência em 15 de junho de 1960 e foi ratificada pelo Brasil em 26 de Novembro de 1965. Com base nessa Convenção, o Governo se comprometeu a formular e implementar uma política nacional para promover a igualdade de oportunidades e de tratamento no mercado do trabalho. 
É significativo o silêncio que ocorreu após a realização do I ENEN, em 1991, quando os movimentos retornaram para suas áreas de atuação e houve um trabalho interno do sentido de buscar alinhar as formas de intervenção junto ao poder público. Uma das principais lições decorrentes desse momento inicial foi a percepção de que a institucionalidade da luta política deveria ser travada no campo das políticas públicas, objetivando construir as bases para as políticas que o Estado deveria assumir como sua perspectiva da temática racial.

O período compreendido de 1991 a 1994 - os quatro anos que antecedem a retomada da mobilização do Movimento Negro (na Marcha Zumbi dos Palmares contra o Racismo, pela Cidadania e Pela Vida, em 20 de novembro de 1995) - reflete o breve período de amadurecimento dessas organizações em um momento em que as economias mundiais buscavam se realinhar em torno do projeto neoliberal como resposta às crises do capitalismo

É importante dar ênfase às demandas definidas pelo movimento negro e às propostas apresentadas no documento da Marcha Zumbi dos Palmares, para ressaltar o contexto dessas proposições:

\section{a) Democratização da informação}

Ao considerar a necessidade de implementação de políticas públicas que promovam a redução das desigualdades raciais no país, o MN propõe que se constitua uma base de dados com vistas à formulação de indicadores que demonstrem, por meio de números, as condições de vida do universo da população negra. Para tanto, estabelece como estratégia a inclusão do quesito raça/cor nos sistemas de informação sobre a população, abrangendo todos os instrumentos cadastrais de serviços utilizados nas instituições públicas.

b) Mercado de trabalho

No início da década de 1990, o amplo debate que se deu em torno das desigualdades raciais no mundo do trabalho, contou com um forte processo de mobilização que proporcionou uma participação significativa de setores sindicais, como a Comissão Nacional contra a Discriminação Racial, ligada à CUT - Central única dos Trabalhadores; a comissão contra a Discriminação Racial, ligadas à CGT - Central Geral dos Trabalhadores; e a Secretaria 
Nacional de Pesquisas de Desenvolvimento da Igualdade Racial, ligada à Força Sindical, em uma articulação com segmentos do Movimento Negro. Dentro desse contexto, a mobilização em torno da problemática no âmbito do trabalho contou com um conjunto de ações no decorrer dessa década, como os relatórios denunciando a omissão do governo em relação às desigualdades raciais e de gênero no mercado de trabalho, os dados obtidos do SEADEDIEESE e IBGE, e os dados levantados pelo CEERT - Centro de Estudos das Relações de Trabalho e Desigualdades, organização ligada ao Movimento Negro. Esses relatórios foram enviados à OIT - Organização Internacional do Trabalho, informando sobre o descumprimento da Convenção 111 e obrigando o governo brasileiro a reconhecer a existência do racismo no âmbito das relações do trabalho como também a assumir uma postura no combate às discriminações neste sentido.

Esse novo momento teve como marco importante o surgimento do INSPIR - Instituto Interamericano pela Igualdade Racial, órgão ligado às centrais sindicais brasileiras, com o objetivo de discutir especificamente a problemática racial no âmbito do trabalho.

Vale ressaltar, o momento paradigmático por que passou o movimento sindical nesse período, pois como afirmou Silva Bento:

\footnotetext{
As mudanças no mundo do trabalho colocam em xeque determinados paradigmas da ação sindical centrada exclusivamente na defesa de salários e de melhores condições de vida, mas distanciadas de um projeto de desenvolvimento capaz de integrar setores marginalizados e sustentar a independência econômica de política. As cúpulas sindicais estão preocupadas com a redução das taxas de sindicalização, com a 'integralidade do trabalhador' e com a incorporação de novos temas, como: Estado de Direito, Defesa da Cidadania, Ecologia e outros que ampliem o raio de ação e a legitimidade de ação sindical (BENTO, 2000:305-6).
}

Percebe-se uma contribuição significativa por parte do Movimento Negro ao propor a incorporação dos aspectos raciais quanto à diversidade dos trabalhadores e à luta antidiscriminatória, com especial atenção à mulher negra em face da sua dupla discriminação quanto ao seu caráter relacional de raça e 
de gênero. Nesse sentido, o documento propõe a implantação de programas de acesso e capacitação para o mercado de trabalho.

\section{c) Educação}

A centralidade dos estudos e referenciais no mundo ocidental estabeleceu uma visão, por um lado, determinista, em que povos em desenvolvimento estariam fadados a um permanente processo de evolução mediado e tutelado pelos povos desenvolvidos. Por outro lado, submeteu alguns grupos humanos a um conjunto de regras nas quais as relações sociais são permeadas por um aparato muitas vezes inadequado a esses segmentos. A estrutura do sistema educacional brasileiro atende a este modelo na medida em que seu contexto apresenta uma lógica, cujos pressupostos reiteram estereótipos e confirmam preconceitos. Pensar a educação sem levar em consideração o peso das relações raciais é negar a realidade sociocultural, pois no Brasil, para além das interferências socioeconômicas, concorrem igualmente os aspectos étnicos raciais nas condições vida da população negra.

Dentro das propostas que constam no documento da Marcha, ao tratar da recuperação, fortalecimento e ampliação da escola pública, fica evidente a necessária relação que se depreende entre a educação escolar e as desigualdades raciais, presente, por exemplo, no elevado índice de repetência e evasão dos alunos dentro de uma cultura homogeneizadora, em detrimento ao reconhecimento às diferenças. Nisso, o documento da Marcha é muito sucinto ao delinear uma revisão dos livros didáticos e manuais escolares, pois, para além desses procedimentos, há que ser aprofundada a análise da estrutura educacional, a partir dos conteúdos curriculares, dos tempos escolares e da diversidade cultural.

Ao definir programas de capacitação permanente de professores que os habilitem a tratar adequadamente a diversidade racial, há uma exigência de o facilitador da aprendizagem considerar a importância da construção da criança negra, sua identidade, refletindo seus valores ancestrais, corporeidade estética. Ao assumir essa especificidade, efetivar-se-iam as ações afirmativas que objetivam romper o círculo perverso de pobreza, fracasso escolar e marginalização social. 
Em síntese, as propostas do Movimento Negro estiveram assentadas nos pressupostos da democracia participativa, tendo no processo educacional um dos seus maiores desafios no enfrentamento da institucionalização das práticas discriminatórias, óbice maior para uma cidadania plena.

d) Cultura e comunicação

A propositura de projeto de lei expressa no documento, tendo como referência os artigos 215, 216 e 242 da Constituição Federal, corporifica as expectativas de representação da população negra brasileira nos espaços públicos. Ao requerer do Estado, em seu papel precípuo de garantia dos plenos direitos culturais e de acesso às fontes da cultura nacional, o Movimento Negro propõe o exercício da função coercitiva do estado em favor da pluralidade de atuação das instituições econômicas, sociais e políticas.

O espaço de representação coletiva revela uma profusão de significados nas relações sociais que são permeados por valores e concepções hierarquizadas. A preservação da memória e as manifestações culturais com toda sua simbologia afirmam identidades no processo civilizatório.

Sendo assim, o questionamento da legitimação das relações sociais de desigualdade e a luta para transformá-las são preocupações essenciais da ação do Movimento Negro. Sua formulação expressa pressupostos de uma política cultural consubstanciada na afirmação de uma identidade negra, na oposição à dominação euro-etnocêntrica, e na luta por autonomia e autodeterminação dos povos.

O documento é claro quando explicita: "promover o mapeamento e tombamento dos sítios e documentos detentores de reminiscências históricas, bem como a proteção das manifestações culturais afro-brasileiras". Ainda nesse tópico, as proposições terminam por asseverar uma necessária "representação proporcional dos grupos étnicos/raciais nas campanhas de comunicação do governo e de entidades que com ele mantenham relações econômicas e políticas".

e) Saúde 
Enquanto prática, o racismo produz uma infinidade de resultados, pois impõe condições deletérias de vida à população vitimizada pela prática racista. As desvantagens acumuladas por negros e negras revelam condições comprometedoras quanto ao peso que os aspectos discriminatórios têm para a população negra no que diz respeito à saúde.

O documento da Marcha enfatiza a necessária observância aos direitos à saúde reprodutiva, dando especial atenção aos mecanismos adotados pelos governos quanto ao controle de natalidade como forma de reduzir a pobreza e marginalização social, além do descaso observado quanto ao acesso à informação e à assistência. As evidências em torno da precariedade da saúde da população negra serviram de considerações acerca de demografia e saúde, tendo sido empiricamente demonstrado o abismo existente entre as condições de saúde da população branca e da população negra, maior contingente em condições socioeconômicas desfavoráveis e em baixo nível de informação.

O documento da Marcha estabeleceu um conjunto de ações que deveriam nortear uma atenção específica em torno da saúde da população negra, considerando-se as preocupações do momento em torno das doenças sexualmente transmissíveis e do vírus HIV; propôs a intensificação e continuidade dos programas de prevenção e atendimento, enfatizando as condições socioeconômicas, combinadas com a dimensão racial; e sugeriu a inclusão do item raça/cor nas fichas epidemiológicas.

No que diz respeito à saúde reprodutiva da mulher negra, o documento da Marcha a observa a maior incidência do risco de morte materna, o menor acesso aos métodos preventivos, o início precoce da atividade sexual e a multiparidade (vários partos), visando a uma política de garantia da saúde integral, considerando as especificidades raciais.

Com ênfase especial, tratou da Anemia Falciforme, Hipertensão e Miomatose. A recorrência comprovada dessas enfermidades com maior incidência na população negra, de acordo com o documento, justifica estratégias para uma ação efetiva no enfrentamento da anemia falciforme, estabelecendo uma atenção especial na habilitação técnica, política e ética, conforme descreve o documento, para que seja efetivado 0 tratamento adequado aos portadores de anemia falciforme e aos portadores do traço falcêmico. 
Quanto às demais enfermidades que têm uma incidência maior na população negra, dentro do conjunto sintomatológico, a miomatose, baseandose na literatura existente a respeito, não apresenta características de marcado caráter socioeconômico, todavia há grande incidência e prevalência de miomas uterinos em mulheres negras, alcançando uma proporção de quatro vezes mais do que em mulheres brancas.

No tocante a hipertensão arterial e às demais enfermidades correlatadas, o documento propôs um acompanhamento desde os primeiros anos de vida. No entanto, em face do caráter socioeconômico, esta é apenas uma medida profilática, sendo, portanto, necessária uma análise mais estrutural da incidência dessas doenças com características étnicas.

\section{f) Combate à violência}

A partir da crescente violência verificada no país, o documento da marcha considera a dimensão agravante que as práticas discriminatórias e o racismo proporcionam. A magnitude da violência racial assume dimensões profundamente inquietantes. A naturalidade com que se convencionou tratar da problemática racial brasileira reflete uma lógica social marcada pela discriminação, estigmatização e criminalização do "diferente". Sendo assim, ao tratar da tipificação da conduta discriminatória no Código Penal, o documento propõe uma mudança substantiva na confirmação do crime, qual seja a tipificação-caracterização, haja vista que a naturalidade não permite a confirmação subjetiva do delito.

Outro aspecto importante na percepção da violência racial é estruturar "um banco de dados a procedimentos e processos criminais, de modo que se possa desagregar e assegurar tratamento estatístico ao quesito raça/cor e melhor conhecer os diferentes aspectos da desigualdade no acesso à justiça”. Até aquele momento, os dados eram precários, os procedimentos de coleta não obedeciam a uma padronização e, na maioria das vezes, não incluíam o quesito raça/cor.

A ausência de informação mais específica no tocante à problemática racial proporcionou um quadro assustador. À guisa de ilustração, pesquisa elaborada pelo ISER - Instituto Superior de Estudos da Religião, realizada em 
São Paulo e Rio de Janeiro, entre os anos de 1993 e 1996, revelou à época que:

Dos 805 mortos pela polícia no Rio de Janeiro entre 1993 e 1996, $29,8 \%$ das vítimas eram descritas como pretas, embora esse grupo racial representasse $8,4 \%$ da população da cidade à época. As vítimas de cor parda representavam $40,4 \%$, embora apenas $31,6 \%$ dos moradores da cidade fossem dessa cor. Já as pessoas de cor branca forma $29,8 \%$ das vítimas, apesar de representarem $60 \%$ do total de habitantes. Em São Paulo, dentre as 203 mortes registradas em confrontos com a polícia entre 1996 e 1999, 13,3\% referiam-se a vítimas de cor preta, embora sua participação na população fosse $3,8 \%$. Os pardos foram $33 \%$ das vítimas, apesar de sua representação no total de habitantes se $23,9 \%$. As vítimas brancas foram 52,7\%, embora esse grupo representasse $69,9 \%$ dos moradores da cidade".

Portanto, o documento apresentou uma proposta muito focada no que diz respeito à violência racial. Em diversos estudos sobre violência, observouse uma maior representação da população negra nos indicadores da violência brasileira.

Em primeira análise, pode-se supor que há uma incidência maior de delitos promovidos por negros em detrimento de brancos, o que não nos possibilita visualizar, empiricamente, que brancos e negros se encontrem igualmente submetido à lei, bem como revelem igual acesso à justiça, sofram idênticos constrangimentos quando submetidos à ação policial.

A proposição de "adoção de disciplinas de direitos humanos e de cidadania, com recorte de raça e de gênero, nos cursos de formação de policiais civis e militares" propugna uma mudança paradigmática quanto às concepções e aos valores na garantia do direito de ampla defesa assegurado pelos princípios constitucionais, tendo como variável o pertencimento racial.

\section{g) Religião}

Com o crescimento das igrejas evangélicas neopentecostais cristãs e fundamentalistas, vem ocorrendo concomitamente a violação de direitos assegurados no artigo 5o inciso $\mathrm{VI}$, da Constituição Federal, que asseguram o livre exercício dos cultos religiosos e garantem a proteção aos locais de culto e suas liturgias. 
Esses segmentos religiosos cristãos vêm estabelecendo uma demonização dos cultos de tradição negro-africana, utilizando a mídia nacional para a promoção da intolerância étnico-religiosa. O Movimento Negro, através de seus ativistas e seus religiosos, assumiu o papel de denunciar e propor medidas para coibir estas práticas, bem como asseverar o cumprimento do que prescreve o ordenamento legal.

Ao propor a inclusão, no Plano Nacional de Direitos Humanos, de legislação específica no âmbito da justiça e segurança, o Movimento Negro objetivou combater as diversas formas de racismo e discriminação racial, transfiguradas no achincalhamento, vilipêndio, deturpação e insuflação de intolerâncias contra negros praticantes das tradições religiosas de matriz africana.

Outro ponto interessante, registrado no documento, foi a proposta de criação de mecanismo legais que permitam a recuperação de instrumentos sagrados dos cultos religiosos de matriz africana, apreendidos no período do império e da república, auge da perseguição e da repressão. Observa-se que as estratégias propostas visam a minimizar a convivência e a passividade com que o Estado brasileiro tem tratado essa temática.

h) Terra

O artigo 68 do Ato das Disposições Constitucionais Transitórias circunscrito na Constituição Federal foi fruto da grande mobilização ocorrida, em virtude da elaboração da Constituição Federal de 1988. Como já foi mencionado, o contexto em que ocorreu a Assembleia Nacional Constituinte ensejou um grande debate, possibilitando ao Movimento Negro, nas mais variadas expressões, estabelecer proposições políticas interferindo no espaço de criação de novos direitos.

A inovação quanto à inserção no ordenamento jurídico-constitucional de um dispositivo que carrega um comando imperativo, estabelecendo a obrigatoriedade de o Estado reconhecer as áreas remanescentes de quilombos como propriedade definitiva, bem como de emitir os títulos dominiais, rompeu paradigmas quanto às demandas da população negra. É importante considerar que a recomendação constitucional expressa uma vontade que deve ser levada 
a termo por um conjunto de ações articuladas entre os procedimentos técnicos legislativo e as pressões políticas do Movimento Negro.

Esse projeto de lei passou por diversas discussões, sofrendo emendas e modificações, dadas as dificuldades históricas em tratar da dívida deixada pelo regime da escravidão dos negros no País. Para além desta garantia legal, o documento apresenta a emergência de se promover um amplo programa de políticas de promoção de igualdade, que tem em seu escopo um modelo de desenvolvimento sustentável.

É importante ressaltar que essas propostas foram entregues ao Presidente da República, por uma comissão composta por membros da Executiva da Marcha, na presença de membros do Grupo de Trabalho Interministerial para Valorização da População Negra - GTI, grupo esse criado como resposta ao conjunto de reivindicações do Movimento Negro, com a finalidade de desenvolver políticas para valorização da população negra.

O que chama a atenção é que, no conjunto das atribuições, não há nenhuma referência ao acompanhamento da implementação de políticas públicas. Os verbos propor, estimular e apoiar são recorrentes, sem, contudo, representar um poder de controle das ações governamentais.

Além disso, a referência aos recursos para o funcionamento do GTI e sua atribuição são vagas remetendo para os órgãos da administração pública federal que integram o Grupo de Trabalho. Durante seu período de funcionamento, esse grupo contou com o apoio técnico e administrativo do Ministério da Justiça, através em uma sala com infraestrutura mínima, um secretário executivo, funcionário com cargo de confiança e uma secretária cedida pelo Ministério da Saúde.

De acordo com as proposições acima descritas havia uma determinação objetiva, da parte do movimento negro, de propor mudanças de caráter estrutural quanto ao tratamento destinado as políticas de integração da pauta racial. Todavia as injunções e percepções políticas governamentais para o período apontavam em outra direção.

A ação governamental, em seu lado mais evidente, foi no sentido de compor organismos governamentais tais como setor de cultura negra, departamentos de cultura afro-indígenas, coordenadorias, Conselhos de defesa 
do negro, como forma de responder aos reclamos cada vez mais intensos nos Estados e municípios. ${ }^{8}$

Notadamente, os esforços significativos de racionalização quanto aos interesses demonstrado pelos governos em efetivar ações da pauta racial, traduzidos por números cada vez maiores de organismos de pouca efetividade mas institucionalmente dotados de capacidade de reduzir as tensões quanto a impermeabilidade da sociedade para essa pauta.

Dessa forma o elenco de organismos estatais criados pode explicitar 0 caráter de uma política calcada mais pelo carisma do que pela real percepção do papel central da integração dessas políticas no interior da gestão pública.

Aqui tematizamos "políticas carismáticas" como sendo políticas que não compõem o arcabouço racional de governança, não cabendo portanto em uma estrutura reconhecida e parte integrante da burocracia governamental, mas fruto de uma subjetividade definida pela sensibilidade e alcance de determinados gestores para com a pauta racial.

Ao tratar a participação como concessão ou demonstração de boa vontade, o governo limita o escopo da política ou os objetivos pretendidos com sua formulação. Negando, portanto, sua necessidade estrutural na mitigação das desigualdades e, por conseguinte, do racismo.

Pode-se, assim, sublinhar as principais expressões dessa política aqui traduzidas de manifestações carismáticas:

a) No âmbito federal:

$\checkmark$ Decreto de 20 de Novembro de 1995 institui o Grupo de Trabalho Interministerial - GTI, no Ministério da Justiça, com a finalidade de desenvolvimento de políticas para a população negra;

$\checkmark$ Decreto de 20 de Novembro de 1996 institui o Grupo de Trabalho para a Eliminação da Discriminação no Emprego e na Ocupação, vinculado ao Ministério do Trabalho.

\footnotetext{
${ }^{8}$ Importantes resgates acerca do reconhecimento formal e da repercussão dos reclamos por direitos sociais e da cidadania são verificados na década de 1980. Entre eles, de fundamental relevância, o Tombamento da Serra da Barriga como patrimônio histórico, em 1984; a criação da Fundação Cultural Palmares, órgão vinculado ao Ministério da Cultura; a criação e instalação do Conselho de Participação e Desenvolvimento da Comunidade Negra, em São Paulo, 1984; a criação e instalação do Conselho de Participação e Integração da Comunidade Negra, em 1988, Minas Gerais; o Conselho Municipal de Defesa dos Direitos do Negro, no Rio de Janeiro, em 1988. Esse conjunto de manifestações governamentais sedimentou a pauta para dentro da agenda pública. (PAULO, em 2002, p.81).
} 
b) No âmbito estadual:

Lei Estadual № 11.321 cria a Coordenadoria Especial do Negro, Governo de São Paulo, em 22 de Dezembro de 1992;

$\checkmark$ Decreto Estadual cria o Conselho Estadual dos Direitos do Negros, Governo do Mato Grosso do Sul, em 12 de janeiro de 1993;

$\checkmark$ Decreto Estadual cria o Conselho de Desenvolvimento da Comunidade Negra, Governo da Bahia, em 02 de março de 1993.

No âmbito municipal:

$\checkmark$ Lei Municipal de Vitória do Espirito Santo № 4.432, de 12 de Maio de 1997, cria o Conselho Municipal do Negro;

$\checkmark$ Criação da Secretaria Municipal para Assuntos da Comunidade Negra na Cidade de Belo Horizonte, em 1998.

A análise que se pode empreender é de que, em um momento favorável, não se poderia ignorar os avanços preconizados pela pressão política de diversos segmentos do movimento negro, mas, em contraponto, por meio desses mecanismos de políticas de estado, percebe-se a inversão quanto as principais demandas ao tratar como ações pontuais e fragmentadas por áreas específicas de interesse do Estado.

O Estado, se vê impelido a buscar responder de forma pragmática, à luz das determinações legais, levando em conta os diversos arranjos preconizados por novas legislações oriundas do cenário internacional, sobretudo nos países marcadamente multirraciais. Segundo D'Adesky,

Embora esses órgãos tenham objetivos comuns com os do Movimento Negro, observamos também que eles têm como tarefas fundamentais assegurar a boa gestão do pluralismo e infletir as eventuais tensões interétnicas que possam surgir no país. Esses órgãos são, antes de tudo, foros do aparelho do 
Estado, e não locais de tomada de decisão do Movimento Negro, operando segundo orientação oficial. (D 'ADESKY, 2001, p. 32)

O governo adotou uma postura cuja visão estava expressa nas manifestações do discurso político do presidente, mas cuja ressonância estava distante das percepções e proposições do movimento social.

Havia profundas divergências entre o que propunha o movimento negro, sobretudo com a mobilização da Marcha Zumbi dos Palmares, em 1995, e a rápida resposta governamental.

Diante de um projeto nacional desenvolvimentista, no qual Fernando Henrique Cardoso ressaltava as diretrizes e metas para a virada histórica do desenvolvimento da sociedade brasileira, a enfatizar a "inclusão dos excluídos" enquanto consequência natural do crescimento econômico. De acordo com a campanha para a Proposta de Governo para o segundo mandato,

\footnotetext{
Incluir os excluídos não significa melhorar a vida de uma parcela de brasileiros em prejuízo dos demais. Nenhum setor precisa perder para que a inclusão se dê na escala desejada. É preciso, sim, que os frutos dessa nova etapa do desenvolvimento brasileiro sejam distribuídos de tal forma em com tal intensidade que permitam melhorar significativamente as condições de vida dos mais pobres. Para isso, é preciso vincular estabilidade e investimento produtivo; crescimento e geração de empregos; competividade e universalização da educação fundamental; equilíbrio fiscal e melhoria das políticas sociais. E uma palavra, simultaneamente, progresso material e progresso social (PROPOSTA...,1998, p.11).
}

No anúncio de um plano de governo que evidentemente não sinalizava para uma ruptura com o padrão de modernização autoritária verificado desde o período republicano, essa aspiração de uma sociedade mediada pelos ventos do mercado, sobretudo europeus, revelava uma indissociável relação com o liberalismo político.

A crença do então presidente FHC era de que as ações de seu governo estavam estruturando as bases institucionais e materiais para uma nova era de desenvolvimento do país, "mais do que uma nova economia, uma nova sociedade" (ibidem, p.11). 
O chamamento para uma intensa mobilização em torno desse projeto pressupunha uma adesão dos movimentos sociais emergentes na luta por garantias de direitos e consolidação de uma nova era definida como: Projeto comum de desenvolvimento com justiça e exercício pleno da cidadania.

Desta forma, as diretrizes do programa de governo ${ }^{9}$ estavam assentadas em quatro eixos para o que fora denominado "mais quatro anos de desenvolvimento para todos". $\mathrm{Na}$ apresentação das linhas gerais do referido programa fica evidenciada sua preferência quanto a uma escolha técnica de configuração dos eixos dos programas com base na política econômica em uma complexa articulação com as políticas sociais.

São notáveis os arranjos institucionais com que se formula e define o modelo de gestão social, combinando os investimentos nas áreas sociais com as medidas imperativas da lógica desenvolvimentista para equacionar da política econômica com as políticas sociais.

O primeiro eixo, Consolidação da estabilidade econômica, objetiva combater os déficits orçamentários nos três níveis de governo, reduzindo a dívida pública em relação ao produto interno, simplificando do sistema tributário e reduzindo o peso dos impostos sobre a produção e o investimento e a exportação, e principalmente, aprofundando a restruturação do setor produtivo, levando adiante o programa de privatização e fortalecendo o Estado no papel de regulador e indutor do desenvolvimento.

O segundo, Promover o crescimento econômico sustentado, a geração de empregos e de oportunidades de renda, com destaque para o fomento do programa Brasil em ação, tem como fundamento os investimentos privados na infraestrutura econômica em consonância com os investimentos sociais.

O terceiro, Eliminar a fome, combater a pobreza e a exclusão social, melhorar a distribuição de renda - enfatiza os programas sociais, com vistas a atingir as populações indigentes e pobres, aumentando o impacto distributivo do gasto público, e promovendo o aumento dos investimentos no desenvolvimento local e integrado envolvendo as empresas estatais em combinação com as iniciativas privadas.

\footnotetext{
${ }^{9}$ Documento de campanha contendo as diretrizes gerais do Programa de Governo com os quais se comprometeu o Então presidente Fernando Henrique Cardoso, $1^{\circ}$ Mandato (1994 - 1997), propostas para o $2^{\circ}$ Mandato (1998 - 2002)
} 
No quarto eixo, Consolidar e aprofundar a democracia, promovendo os direitos humanos, sob os auspícios da transição democrática, o programa visava fortalecer os canais de comunicação entre o governo e a sociedade civil, constituindo espaço de incentivo ao fortalecimento de organizações sociais; incentivo as atividades artísticas e culturais; elaboração do Plano Nacional de Direitos Humanos com o objetivo de combater todas as formas de discriminação; e inserção da temáticas das ações afirmativas em favor das minorias representativas tradicionalmente discriminadas como mulheres, negros e indígenas.

Examinando mais detidamente:

Justiça e Segurança

- Instituir sistema de informações para a proteção dos direitos da população negra, com a participação da Secretaria Nacional dos Direitos Humanos, conselhos da comunidade negra e órgãos responsáveis por políticas públicas nos três níveis de governo;

- Estabelecer, em parceria com entidades do movimento negro e participação do Ministério Público, programa de atendimento a vítimas de discriminação racial;

- Apoiar, nos Estados a criação de delegacias especializadas no atendimento a vítimas de crimes raciais, a exemplo da que existe em São Paulo;

- Promover campanhas de divulgação das leis anti-discriminatória e de condenação do preconceito;

- Apoiar a criação de bancos de dados sobre a situação da população negra, em todos os seus aspectos, para orientar políticas de promoção da comunidade;

- Incluir o quesito" cor" em todos os censos e levantamentos sistemáticos de dados sobre as características e condições de vida da população brasileira.

\section{CULTURA}


- Fortalecer o Centro Nacional de Informação e Referencia da Cultura Negra;

- Incentivar a preservação da memória da participação negra na vida nacional nos acervos de museus, bibliotecas e arquivos públicos, bem como na produção cultural do país;

- Apoiar projetos de capacitação e requalificação de produtores culturais negros, com recursos do Fundo de Amparo ao Trabalhador - FAT;

- Intensificar o intercambio artístico e cultural com os países da África negra;

- Estimular a diversidade racial em obras cinematográficas e teatrais, mediante a presença de atores, diretores e produtores negros.

\section{EDUCAÇÃO}

- Elaborar Plano Nacional sobre Diversidade, comtemplando a questão negra, a exemplo do que se fez em relação à população indígena;

- Estimular a produção de material didático destinado ao ensino fundamental que promova os valores da igualdade e da tolerância, bem como enfatize o papel da comunidade negra, entre outros grupos étnicos, na formação da identidade nacional, de acordo com os parâmetros curriculares nacionais elaborados pelo Ministério da Educação;

- Produzir programas sobre a temática da diversidade a serem transmitidos pela TV Escola;

- Apoiar a criação, nas unidades dos sistema federal de ensino superior, de cursos pré-vestibular gratuitos para estudantes de baixa renda, o que implicitamente aumentará as oportunidades de acesso dos jovens à universidade.

\section{SAÚDE}


- Implementar nos estados o Programa Nacional de Anemia Falciforme, propiciando o diagnóstico e o tratamento dos doentes, bem como o aconselhamento genético;

- Promover a ampliação dos conhecimentos técnicos- científicos sobre a problemática especifica da população negra, mediante financiamento a pesquisas clinicas e epidemiológicas;

- Induzir a reciclagem dos profissionais da área - médicos, enfermeiros, odontólogos, nutricionistas, farmacêuticos, entre outros, tendo em vista, no que diga respeito a cada especialidade, os diversos aspectos da referida problemática, tanto no caso de homens como de mulheres.

Remanescentes dos Quilombos

- Apoiar o mapeamento e classificação das áreas remanescentes de quilombo;

- Promover a titulação de terras, a construção de vias de acesso as comunidades e o fornecimento de energia solar - a exemplo do que se faz no Mato Grosso do Sul;

- Instituir nas comunidades balcões de cidadania, com 0 fornecimento da documentação básica - certidões, cédulas de identidade;

- Desenvolver projetos de apoio ao desenvolvimento sustentado dos quilombos, com linhas próprias de credito;

- Implantar programas específicos de erradicação do analfabetismo, educação fundamental, saúde e profilaxia.

A incorporação do discursos e demandas do Movimento Negro não implicou necessariamente a atenção a relevância da questão racial nas ações de Estado. Sua caracterização mais usual é de um governo arbitrando sobre prováveis tensões oriundas desse grupo em destaque, sem contudo levar em conta sua essencialidade na conformação de um modelo societário capaz de mudanças mais ousadas que não as incorporações e pontualidades das demandas questionadas pelo conjunto da população negra. 
Dessa forma urge considerar que o sistema de planejamento adotados pelo então governo, cujas bases fundamentais estavam centradas na perspectiva racional gerencial administrativa. É necessário nesse estudo dar ênfase às diretrizes gerais adotadas pelo modelo de Governo adotado e a seus processos de formação de políticas públicas.

As respostas apresentadas pelo então governo Fernando Henrique Cardoso (1994-1998;1998-2002), no período dos dois mandatos representaram, em síntese, uma resposta de caráter retórico, que teve na criação de um Grupo de Trabalho Interministerial - GTI ${ }^{10}$, que na prática nunca se efetivou por ausência de articulação interministerial (foi uma ação pontual, restrita à Fundação Cultural Palmares e ao Ministério da Justiça através da Secretaria de Estado de Direitos Humanos).

Visto por outro prisma a criação desse grupo de trabalho representou em verdade uma estratégia governamental que se transformou em uma bem sucedida manobra para o adiamento dos embates que sucederiam as novas tensões quanto a uma agenda positiva e propositiva no tocante a questão racial.

Esse foi um dos aspectos centrais na pesquisa realizada para a dissertação de mestrado. Nos discursos presidenciais do então presidente Fernando Henrique, havias sinais muito claros de que ele preconizava uma igualdade racial, formal, a partir de mecanismos institucionais.

As ações adotadas denotaram um tratamento limitado no que tange as reinvindicações do Movimento Negro, com pouca influência ativa sobre a perspectiva de impactar nas desigualdades raciais, na produção, nos ajustes na distribuição de rendas e de riquezas (função distributiva), sem contar o peso da restrição orçamentária em suas respostas quanto a consolidação de uma real política racial.

No estudos anteriormente realizados, constatamos algumas significativas evasivas no decurso da consolidação dessa manifestação governamental através do GTI:

${ }^{10}$ A composição do Grupo de Trabalho Interministerial estava assim constituída: Casa Civil da Presidência da República - representada pela antiga Secretaria de Estudos Estratégicos; o Ministério da Cultura - representado pela Fundação Cultural Palmares; o Ministério da Justiça - representado pela Secretaria de Estado de Direitos Humanos; o Ministério da Educação e Desporto, o Ministério da Saúde, o Ministério das Relações Exteriores, o Ministério Extraordinário dos Esportes e o Ministério do Planejamento e Orçamento. 
$\checkmark$ De início, há pronta resposta a demandas do $\mathrm{MN}$, no período entre a apresentação das demandas e a edição do Decreto para a constituição do GTI, que ocorreu quase que simultaneamente à entrega do Documento da Marcha;

$\checkmark$ O GTI sinalizava formalmente a responsabilidade de formular propostas, promover mudanças, estimular estudos, divulgar informações, mobilizar recursos dentre outras atribuições que foram mitigadas no seu precário funcionamento;

$\checkmark$ Em face dos desafios que a temática racial passou a ocupar nas manifestas declarações de apreço a realidade da população negra, era de se esperar um maior conjunto de medidas funcionais que desse cabo da consolidação institucional do referido grupo;

$\checkmark$ Todavia a ausência de uma instrução normativa dando conta de sua regulamentação expressou de forma inequívoca a pouca efetividade do órgão, mesmo com a participação de outras instancias ministeriais, a conclusão que chegamos á época não passou de uma constatação de uma intenção protocolar.

$\checkmark$ Por último as determinações econômicas de orientação neoliberal adotadas definitivamente estavam na contramão dos anseios democratizantes pretendidos pelas organizações negras

Em suma, tal processo contraditório ao tempo que sinaliza uma percepção ainda que teórica da questão, não se refletia em uma determinação capaz de integrar as demandas do $\mathrm{MN}$ e efetivá-las, enquanto políticas públicas ainda que de reduzido escopo:

A composição deste Grupo de Trabalho, é possível afirmar, apresentava, em uma rápida observação, uma distinção significativa: por um lado estavam os técnicos de governo com encargos adicionais e tarefas extras a serem cumpridas, além de encaminhamentos setoriais a serem executados; por outro lado, militantes ciosos de suas atribuições enquanto interlocutores privilegiados junto a instancias do Governo Federal, para apontar e propor soluções efetivas para o atendimento à população negra. Esse cenário revelava 0 enorme desafio a ser enfrentado pelos membros do grupo. Além das indefinições das estruturas administrativas e a logística, faltavam Ihe flexibilidade administrativa, pessoal de 
apoio, instalações e equipamentos básicos necessários ao seu funcionamento. (PAULO, 2002, p.86)

De acordo com as observações acima, o GTI serviu como espaço de exercício retórico, compreensão mesma dos membros componentes do próprio grupo, além, claro, de desenvolver um conjunto de estudos e debates. No entanto, houve um detalhamento mínimo para as diretrizes gerais das aspirações da agenda política voltada para a população negra.

$\mathrm{Na}$ apresentação do documento que expressava a posição do Governo em relação ao tema, há referências ao Programa Nacional de Direitos Humanos - PNDH, lançado em 1996, portanto, após um ano de instalação do GTI. Com ênfase nos direitos civis, políticos e sociais, esse documento revelava a consonância necessária com os tratados e convenções internacionais.

No referido documento, o governo define as linhas diretivas gerais de políticas especificas para a população negra, com base no combate às desigualdades raciais, fato inconteste da percepção do governo daquele período.

Nessa direção, as principais ações implementadas foram classificadas em duas categorias: primeiro, 0 fomento a ações de organização e desenvolvimento de dados e indicadores sociais relativos à população negra, através de instalações de conselhos e apoio a grupos de trabalho relacionados ao tema.

Depois, o estímulo a campanhas publicitárias que dessem visibilidade à participação negra no âmbito das propagandas institucionais além do estímulo à discriminação positiva com empenho na desconstrução do imaginário negativo verificado nos livros didáticos.

Concomitante a essas ações, vale destacar uma outra sutil sinalização de abertura de diálogos das representações negras nas diversas instâncias de governo.

O conjunto das organizações negras, há época, já evidenciava uma desconfiança quanto ao grau de eficácia quanto às políticas mitigadoras da extrema pobreza e a ausência plena de direitos para a grande maioria da 
população se negra. Havia um sentimento expressos nas entrevistas ${ }^{11}$ de que as propostas de ações afirmativas, como aceno governamental, sinalizavam o limite entre o debate necessário e o esvaziamento das reivindicações do movimento negro.

Entretanto, se as sinalizações do governo FHC para o conjunto das organizações seguiam na direção de uma incorporação das demandas propostas, por outro lado seu plano de governo tinha como fundamento maior a defesa inconteste da política econômica de caráter neoliberal, presente em fatores como a reforma do Estado, a quebra dos monopólios estatais nas áreas da comunicação e do petróleo, bem como a abertura para o capital estrangeiro.

Nesse contexto, é possível verificar um momento divisor de duas perspectivas históricas, frontalmente distintas no sentido da política: para o conjunto do movimento negro, esse foi o momento de maior expressividade na tradução das aspirações históricas e das reinvindicações negras em sendo transformadas em políticas de Estado.

Da parte do Governo, a demarcação do campo político revelou-se em uma bem engendrada manifestação de apreço ao reconhecimento de uma identidade negra, sem contudo alterar o escopo da política conservadora de manutenção da ordem capitalista, pelo qual as desigualdades são nutridas e mantidas pela lógica do racismo.

Apesar do reconhecimento tácito do racismo, enquanto mecanismos de reprodução das abissais distancias entre negros e brancos, não foram razões suficientes para que o Governo adotasse estratégias políticas capazes de gerar uma aproximação entre o dito, o conhecido e o realizado.

A questão posta é de que forma conciliar as aspirações do Estado reconhecidamente focado nos interesses do grande capital e em suas consequências imediatas - segregação socioespacial, desemprego estrutural, fome e desigualdade racial -, com as perspectivas de políticas raciais.

Eu acho que elas têm papel importante e estratégico. É fato que nós todos reconhecemos que as desigualdades sociais no Brasil decorrem em grande parte do racismo. Essa

11 Á época de conclusão da dissertação de mestrado, entrevistei as principais lideranças do Movimento Negro nacional, sobretudo aqueles que foram dirigentes da Marcha Zumbi, e já na ocasião as manifestações denotavam uma percepção de rumos de que as repostas do Governo levariam a um esvaziamento. 
desigualdade social, na verdade é uma desigualdade racial, ou seja os indivíduos, as pessoas de origem racial específica ocupam determinados espaços na sociedade. Comprovadamente, o quadro de violência, o quadro de miséria que existe no Brasil está associado a essa questão. O desenvolvimento de ações políticas dirigidas à população negra tem um papel no sentido de combater as desigualdades produzidas pelo racismo. Como o racismo se constitui num sistema ideológico, essas políticas teriam como objetivo cria as condições para um grande debate ideológico mesmo. (Militante D, apud PAULO, 2002 )

A percepção estratégica da grande maioria dos militantes negros estava posta com base nas formulações, ainda que fragmentadas e diversas, em relação a um consenso em torno da essencialidade do papel do racismo enquanto limitador dos avanços democratizantes em uma sociedade calcada pelos reflexos ainda bastante presentes da escravidão.

No entanto, a partir do lançamento do Programa Nacional de Direitos Humanos - PNDH - I, em 13 de maio de 1996, o Governo FHC, objetivando responder as demandas do $\mathrm{MN}$, estabeleceu estratégias de combate às discriminações raciais, adotando políticas públicas cujo caráter pontual ressaltamos, dado que as proposições do movimento negro iam na direção de promover mudanças estruturais.

As respostas pontuais, um conjunto de ações especificas no universo de diversas outras ações para os direitos humanos, ou seja de um programa, compondo um amplo leque de expectativas, não refletiam mudanças em meio a um cenário interno a exigir a efetivação de políticas raciais.

O desafio, daquele governo era estabelecer uma capacidade de responder as exigências externas própria do mercado internacional quanto a superação de contextos históricos impeditivos a política de desenvolvimento. Os compromissos internacionais assumidos passam a ser uma exigência para a boa governança, exigindo com isso o cumprimento de importantes acordos no nível internacional e que devem ser implementados nos níveis nacional.

A gestão pública em sua complexidade vem aderir a um modelo institucional de governança que não mais se realiza no escopo reservado da nação, mas a partir de prioridades do capital internacional, incidindo em uma rede complexa de debates sobre políticas com uma variada gama de atores envolvidos nos processos de formulação de políticas. 
Vale registrar que esse cenário no qual essas políticas com foco nas população e grupos vulneráveis vão surgir tem relação direta com um cenário internacional de importantes processos participativos protagonizados pela articulação transnacional dos movimentos sociais e a centralidade para a agenda política dos países.

Com efeito, a realização de diversas conferências mundiais promoveu significativos contrapontos à onda neoliberal, nos anos 1990, os quais, sedimentaram as lutas nacionais:

\begin{abstract}
Cúpula Mundial para crianças (Nova York, 1990); Conferencia sobre Meio Ambiente e Desenvolvimento (Rio de Janeiro, 1992); Conferência Mundial sobre Direitos Humanos (Viena, 1993); Conferência Internacional sobre População e Desenvolvimento (Cairo, 1994); Cúpula para o Desenvolvimento Social (Copenhague, 1995); Quarta Conferência Mundial sobre Mulheres (Beijing, 1995); Conferencia Sobre Assentamentos Humanos (Habitat II, Istambul, 1996) (SILVA; PEREIRA, 2012, p.24).
\end{abstract}

Consequência imediata, destas conferencias, foi a necessidade de alinhamento por parte dos Estados de um conjunto de medidas práticas e políticas o compromisso de orientar, a curto prazo, ações em seus processos decisórios de acordo com os ciclos eleitorais, políticas focalizadas, quando as demandas requerem um prazo maior para aferição de seus impactos.

Talvez aqui resida o impasse entre as denominadas políticas universalistas e as políticas focalizadas. Para efeito deste estudo, as políticas universalistas obedecem os princípios fundamentais do Estado Democrático de Direito, compondo assim o escopo das diretrizes gerais de princípios constitucionais que organizam as políticas sociais.

Quanto a focalização das políticas, sem contradição com as universalistas, elas refletem a necessidade de dar ênfase a determinado aspecto da política, visando atender a segmento especifico dado a sua emergência e necessidade com vias à equidade. Portanto diferentemente de uma polarização entre essas duas categorias, elas podem e devem dialogar constantemente, quando o objeto a ser alcançado assim o exigir, como é o caso das políticas raciais para a população negra.

Ainda na gestão do $\mathrm{FHC}$, temos o lançamento do segundo Programa Nacional de Direitos Humanos - PNDH II, no qual a temática racial volta com 
nova roupagem. O Estado, passa a reconhecer a escravidão e os processos relativos ao tráfico enquanto crimes contra a humanidade.

Nessa direção, é mister o Estado assumir a responsabilidade através do reconhecimento dos resultados das práticas anteriormente estimuladas como responsáveis pela situação presente do conjunto da população negra no país.

Esse momento emblemático, levado por certo pelas diversas manifestações dos organismos internacionais de proteção aos direitos humanos e com a efetiva participação de uma infinidade de Estados-nação mobilizados pelas ações de vilipêndio da escravidão e êxodo forçado dessas populações, promoveu um intenso debate a respeito das formas de reparações.

Para alguns países, as formas deveriam compor um conjunto de diretrizes políticas, dentre elas, a reparação pecuniária como forma de restabelecer as condições mínima para uma inserção dessas populações nas perspectivas materiais e econômicas.

No Brasil, esses debates tiveram nas vozes do Movimento Negro nacional duas correntes efetivas. Uma primeira propunha a criação de fundos de reparação financeira em decorrência da escravidão. Outro segmento propugnava pela criação de um fundo de reparação social destinados a financiar políticas de ação afirmativa e de promoção da igualdade de oportunidades (LIMA, 2010 p.5).

Defendo que nesse ponto há uma inflexão significativa na trajetória desse debate, acreditando que as políticas de ações afirmativas, que no âmbito popular são fragilmente traduzidas em "cotas", não foram uma pretensão objetiva do Movimento negro, mas sim uma bem engendrada manifestação das ações do Governo em consonância com uma pequena parcela especifica de militantes afinados com a política do PSDB, partido do então FHC.

Esse ponto é fundamental porque localiza as percepções e injunções internas ao MN, quanto a pensar uma política de caráter universal e focalizada, negando com isso o caráter residual que a política racial veio a assumir.

Para uma parcela maior do $\mathrm{MN}$, o cuidado na formulação da política racial estava em consonância com os rumos que os debates passaram a ter, 
sobretudo com o advento da participação de ativistas estratégicos aliados as estruturas de governo:

Eu tenho profunda divergência sobre a forma como o Estado vem trabalhando com setores do $M N$, esses setores vêm alimentando esses equívocos do Estado. (...) Eu acho que a bandeira principal do MN deveria ser a de garantir e sustentar as políticas universalistas e não as ações afirmativas. Quando - MN insiste com ações afirmativas, continua retardando e protelando a implementação de políticas porque as ações afirmativas são valorizadas na sua complexidade, na sua especificidade, em seu objeto singular a ser beneficiado e isso só reforça resistências no seio da sociedade Brasileira (...) Ora, se o Estado é quem diz hoje que o negro é o mais pobre entre os pobres, é quem fala dos indicadores socioeconômicos da população negra, queremos que na hora de discutir as políticas, ele considere esse diagnóstico. Existe um fluxo de realidade orçamentária no país que rola todo dia e onde a questão racial não está presente e é aí que ela tem que estar. Por exemplo, existe alguma política de combate à mortalidade infantil no Brasil? Pois é nessa política, com os recursos disponíveis que se deve dizer: Vamos focalizar nas crianças negras porque, pelos próprios indicadores do governo, são elas que mais morrem. Então, sem abandonar o conjunto das crianças a serem atendidas, sem abandonar a perspectiva universal, iremos focalizar nas crianças negras. $E$ mais: queremos lutar para que todos os projetos sociais só possam obter recursos se colocarem como parte obrigatória do projeto, a descrição sobre seu impacto sobre as desigualdades raciais. Eu defendo que dentro de toda e qualquer política social brasileira deve estar a vontade de superação das desigualdades raciais." (Militante G, apud PAULO, 2002)

Dessa afirmação é possível extrair algumas questões importantes para esse estudo. De início, há uma deliberada escolha de membros do MN para a composição das estruturas de governo que obedece a uma participação carismática, ${ }^{12}$ forma pela qual a participação dos ativistas representa uma espécie de concessão na relação entre "casa grande e senzala".

Por outro lado, evidenciam-se alguns impasses no interior do MN quanto as escolhas entre um modelo de política assimilacionista, no qual o governo tenta incorporar os discursos do conjunto da militância, e outro segmento que propõe a integração das políticas de caráter racial, determinada

${ }^{12}$ Carismática aqui pressupõe uma atitude de escolha por afeição, sem qualquer racionalidade de gestão política. Define também as formas como até hoje as políticas de caráter racial têm sido tratadas, não havendo assim uma efetiva transversalidade nem uma intersetorialidade na conformação dessas políticas. 
pela incidência das vulnerabilidades e carências que recaem sobre a população negra.

Nesse sentido, a incorporação passa a significar um processo pelo qual a apropriação do discurso e a cooptação tornam frágil a possibilidade de um protagonismo e autonomia dos envolvidos no processo de proposição e formulação da política.

Contrariamente, a perspectiva de uma efetiva integração a partir das correlações de forças na construção das políticas raciais - ainda que levando em consideração a expressividade dos números e indicadores, as definições racionais e objetivas da política - perde-se na fragmentação das ações estanques e factuais, tendo como consequência o escopo reduzido quanto ao alcance, conforme afirmava

Se as políticas de ação afirmativa forem reduzidas a políticas de cotas dos $20 \%$ que é um número mágico inventado, elas vão construir uma inclusão minoritária e subordinada que acho que é o projeto político que o Estado brasileiro tem para com os negros. (Militante C, apud PAULO, 2002).

Ainda nessa direção podemos observar que para alguns militantes a

Política de ação afirmativa é uma reforma. Temos que ter isso claro. Mas num Estado tão conservador em relação à questão racial como o Brasil, isto vira revolução. [As políticas de ação afirmativa] não vão resolver todos os problemas do combate à discriminação, nem das desigualdades raciais no Brasil, mas vão possibilitar em alguns espaços que hoje são caixas brancas, carreiras inclusive de elite, a capacitação e a entrada dos negros nesses espaços, consequentemente, a mais vai criar um espaço de interação e de incentivo à existência de profissionais mais qualificados e criar uma vanguarda, uma vanguarda negra dirigente e política também. (Militante D, apud PAULO, 2002)

Desta maneira, as Políticas raciais implementadas no período que compreendido entre 1995 a 2002, revelaram-se um marco na política racial, muito menos pelas sinalizações do Governo, mas sobretudo pelo efervescente cenário no âmbito internacional e nacional. 
O período aqui denominado de política desenvolvimentista irá compreender a fase de tentativa de superação do atraso econômico, tema já fartamente justificado pelas condições objetivas advindas do colonialismo e seu congelamento.

Para que essa caracterização possa explicitar de que forma o diálogo entre as políticas desenvolvimentistas e a construção do projeto nacional seja capaz de cotejar a temática racial, é necessário aliar pretensões de desenvolvimento econômico com a dimensão social.

Para Cepêda (2012), a diferença fundamental entre o desenvolvimento e o desenvolvimentismo, para além de uma distinção semântica, configura uma importante inflexão, na definição das configurações políticas dentro do contexto nacional.

No espectro do desenvolvimento, as bases que estruturam esse pensamento têm suas diretrizes voltadas para o livre mercado e maximização de ganhos, confundindo se por vezes com crescimento econômico.

O desenvolvimentismo, para a mesma autora, significa aportar às configurações históricas um caráter de dimensão social, que detém as bases para um projeto de transformação social, profunda, orientada pelo Estado, estabelecendo um forte relação da economia com o avanço social.

\title{
Desta forma,
}

\begin{abstract}
O desenvolvimentismo nasce de uma constatação de deficiência estrutural e crônica como base lógica de intervenção com objetivo de transformação. Portanto, é mais que desenvolvimento: é mudança social sistêmica, orientada e sustentada politicamente. O desenvolvimentismo, percebido como projeto, é produto de um momento datado e de uma conjuntura específica, mas mesmo nessa modalidade foi capaz de produzir um arranjo teórico e político capaz de ser atualizado e realinhado em outras situações históricas. (CEPÊDA, 2012, p.79)
\end{abstract}

Portanto o contexto em que se insere a política desenvolvimentista e seu encontro com a questão racial se dá em um cenário cujos marcos referenciais de análise não se desvencilharam da anteriormente denominada descolonização congelada, ao tempo em que se orienta uma política para uma significativa mudança no rumo da política econômica.

Os anos 2000, a partir das premissas desenvolvimentistas, irão estabelecer um importante debate quanto ao problema nacional. $O$ atraso herdado do período colonial e os decorrentes processos históricos dão lugar a um novo padrão de desigualdades desafiador frente a uma recomposição do tecido social que seja capaz de implementar novas políticas com características desenvolvimentistas. 
A construção do pensamento social brasileiro, no transcorrer dos séculos que compreendem as principais fases do surgimento do Estado brasileiro, possibilita uma efetiva explicação dos dilemas sociais em curso na atualidade em torno da questão racial.

Desta forma, se adotamos as desigualdades enquanto referencial primeiro das nossas percepções da realidade social brasileira, teremos temas como violência, criminalidade, ausência de direitos, em uma narrativa persistente das mazelas de um passado fragmentado pelas interrupções históricas derivadas de um passado escravista.

Por certa (não correta) percepção seletiva, constrói-se uma visão por vezes confortável da evolução da história, não levando em conta as condições objetivas nas quais se efetivaram uma naturalização dos atuais desníveis de condições de vida de parcela significativa da sociedade.

Ao tratar dos temas mais instigantes para uma explicação dessas anomalias sociais, evidenciam-se a predisposição e o pressuposto das políticas mitigadoras das desigualdades. O ponto cego que se pretende evidenciar é que no bojo dessas análises nunca se situa a questão racial que perpassa todos os processos da historiografia nacional.

Mas para delimitar um período mais recente, é preciso recuperar brevemente os séculos que antecedem a esse momento, tratando dos aspectos institucionalizados da expansão comercial da Europa, importando situar esse marco referencial para localizar a origem das aspirações nacionais atuais por semblante mais afeito a realidade expansionista do capital.

As expectativas geradas nas elites nacionais perduram até hoje quando se põe a descoberto as pretéritas necessidades de expansão do capital comercial e as atuais demandas por abertura de mercado e suas decorrentes antíteses de superação das desigualdades sociais.

Sem embargo, o transcurso histórico das primeiras investidas coloniais, passa pela anuência de um império comprometido pelo capital estrangeiro, chegando a república, momento no qual as primeiras iniciativas são perpassadas por avanços e retrocessos.

A questão racial e a luta de classe têm sido até aqui o principal objeto da reflexão histórica para efeito desse estudo, importando trazer ao debate 0 papel central que as relações raciais têm para os estudos da formação econômica e social. 
Diversos autores trouxeram contribuições para situar o desenvolvimento capitalista brasileiro, com especial atenção às contribuições de pensadores marxistas. As incursões teóricas em torno da história do Brasil, ao requerer modelos de análise teórica do marxismo clássico, pretenderam alcançar os fundamentos da democracia brasileira.

Tomando como questão central as interpretações exegéticas em torno da transição do escravismo para a sociedade de classes, a análise interpretativa do "problema racial" e das relações de classe se configura enquanto uma das bases mais efetivas para o aprofundamento das fases por nós assumidas como fundamentais para compreensão da questão racial.

A influência dos debates atuais sobre desenvolvimentismo, sobretudo nos países latino-americanos, leva por certo à análise profunda dos processos de independência desses países. Apesar das peculiaridades de que se reveste a história de cada um desses países, em um ponto há convergência - o traço marcante do colonialismo que persistente em alguns até o presente.

Assumindo essa perspectiva enquanto marca indelével dos entraves estruturais quanto a uma autonomia efetiva para o desenvolvimento, observamse no transcurso da história especificidades características do padrão de uma burguesia muito específica. As lutas de independência estavam fortemente marcadas pela manutenção dos privilégios dos setores das elites. Ou seja aqueles que já detinham o poder econômico mantiveram também o poder político.

A restruturação hegemônica das elites no Brasil torna-se, portanto, uma questão importante para a análise dos atuais impasses para pensar um desenvolvimento que tenha em seu conteúdo o caráter autônomo pelo qual se pode pensar um projeto democrático cujas bases sejam diferentes do modelo tradicional em que as desigualdades sociais não se confundem com as desigualdades raciais mas se retroalimentam.

A vasta literatura em torno da questão do desenvolvimento capitalista nacional tem significativa importância nas contribuições de Florestan Fernandes, sobretudo quando o mesmo afirma que a descolonização foi um processo congelado.

Sua crítica assenta-se dentro do espectro de que o processo de descolonização pressupõe um movimento que seja efetivamente radical para 
que as bases do capitalismo dependente sejam transmutadas em uma economia democrática fortalecida por um estado nacional independente.

A independência que se criava era a dos estamentos privilegiados e o Estado nacional independente nascia antes da Nação, como expressão da vontade coletiva e dos interesses de dominação econômica, social e política da gente válida, ou seja, como maneira de organizar a voz política dos donos de fato do poder e de dar continuidade às estruturas de produção e de exportação montadas previamente (FERNANDES, 1981, p.81).

Parece-nos questão central, nessa quase passagem do colonialismo para o neocolonialismo, que a transição não se dá de maneira a substituir um período por outro mas evidentemente pela adequação gradual da manutenção dos poderes políticos e o controle da nação.

Desta forma, as movimentações das elites, seguiam no sentido de garantir a mudança do modelo escravista no plano formal, mas a assegurar que as bases estruturais da colonização se mantivessem inalteradas (FERNANDES, 1981, p.82).

A prevalência dessa linha de raciocínio nos parece dotada de um vigor capaz de traduzir nos dias atuais a percepção de que essas mudanças verificadas quanto da transição do trabalho escravo para o trabalho livre se deram de forma satisfatória, restando apenas aspectos residuais do modelo escravista, que consistiriam na inadequação cultural da população negra ao novo padrão econômico de produção.

A nação insere-se nas grandes aspirações do industrialismo, sem contudo, resolver uma questão central que é promover de fato a descolonização. Nesse sentido as contribuições contundentes de um outro autor, Fanon (2013, p.51), ainda que não tenha se referido ao Brasil, ilustram de forma insofismável esses impasses teóricos políticos. Ao afirmar categoricamente o papel radical do processo da descolonização:

a descolonização é, simplesmente, a substituição de uma "espécie" de homens por uma outra "espécie" de homens. Sem transição, há substituição total, completa, absoluta. Certamente, também se poderá mostrar o surgimento de uma nova nação, a instalação de um Estado novo, suas relações diplomáticas, sua orientação política, econômica. Mas decidimos, precisamente, falar dessa espécie de tabua rasa que define, no início, toda descolonização. Sua importância inabitual é que ela constitui, desde o primeiro dia, a reivindicação mínima do colonizado. $\mathrm{Na}$ verdade, a prova do sucesso reside num panorama social inteiramente modificado. A importância extraordinária dessa 
transformação é de que ela é desejada, reclamada, exigida. A necessidade dessa transformação existe em estado bruto, impetuoso e obrigatório, na consciência e na vida de homens e das mulheres colonizados. Mas a eventualidade dessa mudança é também vivida sob a forma de um futuro terrificante na consciência de uma outra "espécie" de homens e mulheres: os colonos. (FANON, 2013, p.5152)

A crítica do supracitado autor segue na direção de que a descolonização se propõe a modificar a ordem do mundo, não sendo portanto uma operação mágica ou de negociações amigáveis. A descolonização como processo histórico assume a radicalidade que se insere em seu contexto mais agudo, a mudança de um paradigma integral.

A necessidade de um projeto nacional democrático esbarrou nas dificuldades de promoção de uma descolonização, de acordo com Florestan, no entanto, o desenvolvimento se deu às custas da exploração do trabalho e ampliação das desigualdades.

Desta forma, entende-se, pois, que as bases de um desenvolvimento com desigualdades estavam plantados, o que viria a sedimentar uma naturalização das desigualdades sociais observadas, sem um questionamento profundo da situação colonial e dos elementos constituintes do modelo econômico com base na escravidão.

O novo programa que se inaugura deita por terra a melhor oportunidade de se reparar na origem os males da escravidão e de seu pilar de sustentação - a desigualdade com base no racismo.

Não obstante, o desenvolvimento sempre foi paradoxal no que diz respeito a pensar uma sociedade com as características do pluralismo étnico. O capital industrial forjará um modelo de sociedade inserida no mundo da produção capitalista que não irá buscar equacionar a questão racial, através da integração desse contingente populacional.

As argumentações para essa não integração, em determinado momento, seguem a lógica explicativa da não preparação dos antigos trabalhadores escravizados para o novo modelo em gestão; por outro lado, as determinações do capital industrial afinavam-se à pretensão de inserção da mão-de-obra estrangeira aos moldes do projeto universalista eurocêntrico.

Talvez esse contexto nos permita compreender que o ponto de convergência entre o capitalismo inaugurado aqui e os ideias e uma sociedade 
imaginada estavam em dissonância com as então recentes formulações do racismo europeu. ${ }^{13}$

O retorno do debate no tocante a questão racial sempre teve no decorrer do processo civilizatório nacional, entre as idas e vindas, um recomeço, como se a nação a todo momento estivesse reatualizando os pilares civilizatórios nos quais estivessem contidos a confirmação de ideais racistas dissimulados pela lógica universalista.

Se o tema retorna de maneira decisiva hoje, revela uma mal disfarçada seletividade com que se construiu as visões lacunares do papel central de quem hoje representa a maior expressão das ausências das políticas sociais. As determinações históricas, negadas no passado, confirmam os atuais debates acalorados acerca da redução da maioridade penal, política mais eficiente de encarceramento, genocídio da juventude, combate à criminalidade.

As políticas sociais e as políticas econômicas procuram evidenciar programas e ações que sinalizem uma reversão do quadro de deterioração social em que se encontra a nação atualmente. No entanto, essa busca frenética por um projeto nacional inclusivo, mobiliza a coletividade para 0 desenvolvimento econômico, deixando tudo o mais para um futuro.

O que se percebe é que, na lógica das soluções mitigadoras dessas iniquidades, as propostas passam por uma incorporação de fórmulas mágicas e rápidas para a solução de uma questão que requer fundamentalmente a revisão radical dos modelos explicativos, quer do ponto de vista do desenvolvimento econômico, quer do ponto de vista das implicações das subjetividades envolvidas marcadas pela lógica do racismo estrutural.

Importa afirmar que a progressiva vulnerabilidade da população negra no país, desde sempre não é fato isolado para o resto da população nacional, está ficando inequívoco que o problema não é apenas uma questão pontual, mas uma evidência do modelo social escolhido e tido como uma das mais perversas formas de constituição de uma nação.

A inter-relação da política econômica com o racismo, enquanto sistema, gradualmente apresenta seus pontos de tensão. Os padrões de desenvolvimento escolhidos, desde a colonização aos dias atuais, obedeceram

$13 \mathrm{O}$ racismo cientifico teve seu apogeu exatamente no momento em que se buscava erigir as estruturas do modelo de sociedade capitalista que vigorou nesse século. 
a uma lógica estratificada com base nas diferenças étnico-raciais, sob o manto das estruturas nacionais integradoras.

A burguesia nacional, ao protagonizar um projeto nacionalista, tendo a economia como epicentro, nunca pretendeu criar as condições de produção da riqueza a serviço da nação.

O Estado, em sua conformação, apesar de sinalizar para formas novas de relações sociais, sempre foi o espaço central das garantias de privilégios dos grupos originários da burguesia nacional oriunda desde a colonização.

Evidencia-se no atual momento, o temor amplificado das massas de negros e pobres, em sua grande maioria, a ameaçar a pretendida estabilidade econômica. Não por acaso, as instâncias repressivas do Estado sem põem em alerta para debelar essas ameaças.

Por um lado, tem-se o recrudescimento das representações legislativas com o aumento exponencial de grupos e segmentos conservadores, por outro, o aumento gradual da atuação das forças policiais no combate aos conflitos sociais.

\section{O desenvolvimento nacional como utopia burguesa}

O desenvolvimentismo, segundo Sampaio Jr., surgiu como corrente de pensamento debruçada sobre a necessidade de desatar os nós que desassociaram classicamente o desenvolvimento capitalista e os problemas da população nos países de desenvolvimento tardio.

Para os desenvolvimentistas, era necessário criar as bases materiais, sociais e culturais que permitiriam expandir as relações capitalistas de produção, controlando seu ritmo e direções em nível doméstico.

Assim seria possível combinar acumulação de capital, desenvolvimento das forças produtivas e atendimento das necessidades da população, num momento de consolidação das estruturas do capitalismo nacional. Em suma, tratava-se de uma tentativa de integrar o desenvolvimento capitalista e as necessidades de uma sociedade civil em processo de formação. 
Para tornar factível esse projeto, os desenvolvimentistas partiam de um diagnóstico: as economias latino-americanas não conseguiam controlar sua própria direção em virtude da elevada dependência externa e da extrema desigualdade entre as classes sociais.

Em suma, isso implicava dizer que, de um lado, a soberania estava bloqueada pelo capital especulativo; de outro que a luta de classes, motor do capitalismo, sofria os constrangimentos de uma estrutura social absurdamente segregadora.

Esses elementos foram apontados como causas principais do subdesenvolvimento e, neste sentido, seriam os alvos centrais aptos a garantir a transição e a saída do subdesenvolvimento.

Era necessário, pois, enfrentar o imperialismo calcinado no desenvolvimento desigual e combinado e, de outro, destruir as condições objetivas e subjetivas que sustentam o regime de segregação social, sobretudo o latifúndio e os privilégios de setores burgueses, cuja força estava estruturada na superexploração de uma força de trabalho condenada à pobreza e à miséria. Todos estes elementos eram contingências históricas passíveis de serem superadas por uma vontade política nacional. ${ }^{14}$

Para uma gama variada de autores, portanto, o desenvolvimento capitalista nacional não resolveria espontaneamente as grandes mazelas sociais. Seria necessário construir as condições para a integração da população no progresso técnico, subordinando a acumulação capitalista a uma vontade coletiva. Para tanto, seria necessário também formar uma burguesia nacional capaz de confrontar interesses externos.

$\mathrm{Na}$ prática, um arsenal de políticas foi formado: fortalecimento da indústria nacional, organização de instituições públicas e formação de uma inteligência nacional capaz de conduzir técnica e politicamente os órgãos de Estado. Na América Latina essa escola de pensamento foi bem representada

14 Importante se faz caracterizar a definição de "vontade política", expressão tão em voga em nossa cultura de gestão, aspecto que a nosso ver configura uma similaridade com a dimensão patrimonialista sob a qual reside uma percepção de que as decisões de gestão passam pela anuência do signatário decisor de determinada política e não pelo compromisso e reponsabilidade social. 
por Raul Prebisch e toda a Cepal; no Brasil, o principal expoente foi Celso Furtado. ${ }^{15}$

A eclosão de diversos golpes de Estado em toda a América Latina destruiu as possibilidades de aplicação de um modelo de capitalismo civilizado, transformando a revolução burguesa em uma contrarrevolução permanente.

O capitalismo dependente se consolida como única via, consolidando a articulação entre dependência externa e segregação social como eixos estruturais do processo de acumulação. A superexploração da força de trabalho tornou-se a pedra fundamental do padrão brasileiro de acumulação, mantendo-se intocado o desequilíbrio profundo existente entre capital e trabalho.

A alteração das bases materiais sobre as quais se estruturou 0 desenvolvimentismo diluiu a oposição entre imperialismo e desenvolvimento. $O$ capital internacional passou de inimigo a condição indispensável para o próprio desenvolvimento em condições periféricas. Fernando Henrique Cardoso e Enzo Falleto construíram o primeiro movimento que diluiu estas contradições. ${ }^{16}$

Logo após, Maria da Conceição Tavares e José Serra construíram as bases teóricas que diluíram a oposição entre pobreza e desenvolvimento autodeterminado. Para eles, a ausência de integração social deixava de ser um obstáculo, transformando-se em mero resíduo colonial incapaz de frear o desenvolvimento do país.

As revisões teóricas propugnadas pelos autores supracitados eram reflexo direto das mudanças operadas no seio do capitalismo ao nível mundial em geral e na América Latina em particular. Reformas estruturais foram suspensas em favor da consolidação de um regime antissocial e antidemocrático. Conforme pondera Sampaio Junior:

Enfim, impugnava-se a própria noção de subdesenvolvimento como uma realidade composta pela totalidade de nexos orgânicos entre: controle da economia pelo capital internacional, latifúndio,

15 A CEPAL foi criada em 1948 pela organização das Nações Unidas (ONU). Destacam-se entre os cepalinos brasileiros o notável economista Celso Furtado, além de Maria Conceição Tavares, João Manuel Cardoso de Mello, entre tantos outros discípulos do uruguaio Raúl Prebisch.

${ }^{16}$ Esses autores, desenvolveram o conceito de "capitalismo dependente" Contrapondo-se à ideia do "subdesenvolvimento" tal como essa figurava nas interpretações "etapistas-dualistas, demonstrando que cada experiência de dependência é própria, fruto da sua historicidade, sendo portanto particular, operando para dentro e para fora. 
desemprego estrutural, marginalidade social, inadequação tecnológica, heterogeneidade estrutural, estreiteza e precariedade do mercado interno, controle do Estado por burguesias aculturadas, modernização dos padrões de consumo, posição subalterna na divisão internacional do trabalho, transferência de recursos ao exterior, tendência estrutural a concentração do progresso técnico, colonialismo interno, instabilidade monetária, tendência estrutural à estagnação, fragilidade fiscal, deterioração dos termos de troca, tendência estrutural a desequilíbrios externos, irracionalidade econômica, dependência tecnológica, financeira e cultural, precariedade dos centros internos de decisão, ameaça permanente de crises de reversão estrutural (SAMPAIO JUNIOR, 2012, p. 278).

\section{O neodesenvolvimentismo como simulacro do desenvolvimento}

O neodesenvolvimentismo é fenômeno recente e localizado, não ultrapassando as fronteiras nacionais. Segundo Sampaio Júnior (2012), tratase mais de uma disputa intra-governamental pelo controle da política econômica do que de uma teoria capaz de demarcar território para além das disputas palacianas.

Em suma, dois grupos disputam o Estado neste quesito específico: a ala monetarista, mais identificada com os postulados neoliberais, e a ala autodenominada desenvolvimentista, setor que pretende aliar desenvolvimento com equilíbrio social.

O neodesenvolvimentismo ganha força enquanto expressão teórica de um tempo a partir do segundo mandato do governo Lula, quando as taxas de crescimento econômico, emprego, salários e consumo sobem a níveis consideráveis, se comparadas com o cenário imediatamente anterior.

Acreditava-se neste aspecto que uma nova onda de desenvolvimento estava aberta. Este neodesenvolvimentismo teria, contudo, algumas diferenças em relação ao velho: afasta-se do populismo fiscal, do nacionalismo anacrônico e da complacência com a inflação; com ele compartilharia, de outro lado, o compromisso com a industrialização, a questão social, o crescimento econômico e o papel do Estado enquanto regulador da economia.

Aliaria, desta forma, aspectos mais positivos do neoliberalismo com aspectos positivos do velho desenvolvimentismo, conformando uma terceira via entre ambos. 
Desenvolvimento e crescimento econômico tornam-se fenômenos indistintos e o debate interno aos economistas passa a centrar nos instrumentos de política macroeconômica que permitam conciliar crescimento econômico, equilíbrio fiscal, política industrial e orçamento para as políticas sociais.

Não há, nestes termos, qualquer confronto direto aos pressupostos neoliberais que conduziram a política econômica do Estado brasileiro desde os anos 1990, mas atenuação dos seus efeitos mais deletérios. Em suma, por um prisma válido, teríamos apenas uma versão amena do neoliberalismo, contrabalanceada por medidas pontuais que em nada ameaçam a ordem burguesa. 


\section{CAPÍTULO 4 - A POLÍTICA DE PROMOÇÃO DA IGUALDADE RACIAL}

O contexto das políticas de promoção da igualdade racial nasce em meio a uma profusão de fatores que tentam reinserir a interlocução entre desenvolvimento econômico e as expectativas de consolidação dos direitos sociais.

Tomando como parâmetro o período compreendido entre os anos 1990 até as primeiras décadas dos 2000, teremos um momento de profunda efervescência no que diz respeito às mais significativas mudanças quanto ao cenário político nacional e internacional para a questão racial.

Esse período tem importância, sobretudo, pelo que representou em termo de esforços do Estado brasileiro na promoção de um tratamento mais adequado destinados às populações negras, segmento majoritário no país.

No que concerne às ações governamentais, pode-se elencar um conjunto significativo de ações que expressaram o vigor dos debates e suas respectivas respostas formais, a saber: 1 - a realização da III Conferência Mundial contra Racismo, Discriminação Racial, Xenofobia e Intolerância correlata, em 2001; 2 - programas e ações relativas à promoção da igualdade racial criados em alguns ministérios entre 2001 e 2002; 3 - Em 2002, a vitória do PT nas eleições presidenciais, defendendo o programa do Partido Brasil sem Racismo, será a base teórica para a criação da Secretaria Especial de Políticas de Promoção da lgualdade Racial (SEPPIR).

As mobilizações preparatórias para a Conferência Mundial contra 0 Racismo, Discriminação Racial, Xenofobia e Intolerâncias Correlatas, convocada pela ONU e realizada em Durban, África do Sul (2001), tiveram seu momento mobilizador ainda no ano de 2000, em meio a uma necessidade de reestruturação da política econômica e às deliberações para a construção da conferência.

Houve a criação de um comitê impulsor, organismo em torno do qual um conjunto de lideranças negras de diversas representações do MN e alguns 
parlamentares negros se envolveu no sentido de disseminar o processo de difusão e articulação para a referida reunião.

Dois pontos estratégicos estavam à época sendo pensados: primeiro, oportunizar essa mobilização para construir um projeto de unidade das organizações do MN; segundo, estabelecer uma interlocução entre Estado e sociedade, pela qual as históricas pautas fossem gradativamente transformadas em políticas de Estado.

Explicitamente, as percepções do MN estavam centradas na expectativa de adensar as sinalizações do Governo com políticas integradoras, diante do amplo conjunto de sinalizações positivas, em um cenário internacional favorável e pelo significado da Conferencia Mundial; ao tempo em que possibilitava a identificação de uma potencialidade das organizações negras do hemisfério sul.

Sem dúvida, esse é um dos marcos históricos de maior visibilidade das questões raciais propostas pelos diversos setores do $\mathrm{MN}$, no Brasil e demais países latino-americanos.

Para a realidade nacional, nesse contexto, em meio a incontestes desigualdades étnico-raciais, não se tratava mais de negar as evidentes assimetrias das desigualdades étnicos raciais, mas de o governo cotejar as políticas universalistas com foco na pobreza e nas populações historicamente marginalizadas.

A despeito das primeiras iniciativas de políticas afirmativas, havia um clima de desvelamento do projeto social em debate. Na corrente do modelo desenvolvimentista ficava evidente que as históricas retrações de envolvimento da população negra no processo de inserção precisavam ser encaradas.

Com advento da conferência, a necessidade de avaliação dos indicadores sociais, com ênfase na população negra, constitui uma radiografia com evidências muito nítidas. O cenário apontava uma desigualdade racial estarrecedora, como afirmou Roberto Borges Martins, ${ }^{17}$ por ocasião da primeira apresentação dos dados estatísticos em torno da população negra, a partir de estudos realizados pelo IPEA, em 2000.

\footnotetext{
${ }^{17} \mathrm{Na}$ ocasião, presidente do IPEA.
} 
O déficit social para consolidar uma identidade nacional, de fato, esbarrava nas condições de vida de uma parcela enorme da sociedade brasileira, resultado do legado colonial e de suas consequências imediatas.

\section{A CRIAÇÃO DA SEPPIR}

A política de igualdade racial, nos últimos anos, ocupou significativos espaços de debate nos meios acadêmicos, nas empresas, e nas agendas governamentais e legislativas. Fruto de uma intermitente luta do movimento negro brasileiro, esse processo foi lento e não isento de contradições, muitas delas advindas da própria maneira com que as expressões da luta de enfrentamento do racismo e suas variadas formas discriminatórias são percebidas pelo próprio movimento e a população negra do país.

A institucionalização tardia do tema pode ser atribuída, inicialmente, a vários fatores, como o lento processo de incorporação dos debates no âmbito da esquerda; a relutância cultural do país em admitir que fora erigido sobre pilares euroetnocêntricos; a negação e ou omissão da historiografia brasileira quanto ao passado escravocrata, dentre outros aspectos igualmente potenciais da invisibilidade das desigualdades entre negros e brancos.

No início do ano 2000, entre fatos de grande expectativa para a política racial, ocorre a eleição do presidente Luiz Inácio Lula (2003-2006), que assumira compromissos com a pauta racial, ao aglutinar as demandas decorrentes do movimento negro nacional e as diretrizes da Declaração e do Programa de ação da Conferencia Mundial. ${ }^{18}$ Essa conjunção de fatores; 0 Plano de Governo do PT, Brasil sem Racismo ${ }^{19}$, a uma maior mobilização do

\footnotetext{
${ }^{18}$ a) Plano de Ação de Durban, produto da III Conferência Mundial contra o Racismo, a Discriminação Racial, Xenofobia e Intolerância Correlata, no qual governos e organizações da sociedade civil, de todas as partes do mundo, foram conclamados a elaborar medidas globais contra o racismo, a discriminação, a intolerância e a xenofobia. Desse documento extraíram-se os desafios a serem enfrentados pelo Estado brasileiro.

19 b) Brasil sem Racismo, documento elaborado para o programa de governo indicando a implementação de políticas de promoção da igualdade racial nas áreas do trabalho, emprego e renda, cultura e comunicação, educação e saúde, terras de quilombos, mulheres negras, juventude, segurança e relações internacionais.
} 
Movimento Negro em torno de uma pauta institucional. Foram determinantes significativos para um novo momento da política racial.

A Secretaria Especial de Políticas para Promoção da Igualdade Racial - SEPPIR em 2003, consagrou um processo relativamente longo quanto a incorporação dessas demandas.

O panorama das políticas raciais passou a ocupar uma dimensão crucial com a instalação da SEPPIR, requerendo novos arranjos institucionais exigidos por essa inovação na inclusão temática desta política, influenciando o comportamento dos atores sociais e dos membros de governo em torno da referida política.

Desde 1995 com a realização da $1^{\underline{a}}$ Marcha Zumbi dos Palmares contra - Racismo, pela Cidadania e a Vida, o movimento negro expressara a necessidade de uma série de políticas públicas através de uma pauta política formalmente protocolada junto ao Governo Federal.

A SEPPIR representou uma resposta a materialização de um anseio há muito esperado pelo conjunto das organizações negras nacionais. Sua criação se deveu a uma forte pressão do movimento negro, ante a necessidade de constituição de uma instância interna na estrutura governamental com atribuição específica de formular e articular políticas para a promoção da igualdade racial.

Esta inflexão se deu com a mudança de governo, quando na disputa das eleições em 2002 houve uma alteração no rumo das ações desenvolvidas no âmbito federal. A vinculação da SEPPIR à Presidência da República, e inicialmente com status de ministério, deu maior credibilidade às demais instâncias governamentais, conferindo-Ihe assim um papel político de interesse do executivo federal.

A SEPPIR tem como objetivo a formulação, coordenação e articulação de políticas para a promoção da igualdade racial, de políticas de ação afirmativa (inclusive de acompanhamento da implementação de legislação a respeito), assim como da proteção de direitos de indivíduos e grupos raciais afetados pela discriminação racial, com ênfase na população negra. 
Para realizar seus objetivos, a SEPPIR enfrenta ainda os desafios de consolidar o tema da igualdade racial no âmbito do governo federal, envolver os diferentes ministérios setoriais no combate aos efeitos da discriminação e às desigualdades raciais, mobilizar uma importante capacidade de coordenação e estabelecer vínculos institucionais efetivos não apenas com a sociedade civil, mas também com organismos como o Ministério Público e os governos estaduais e municipais.

Sua missão tem caráter estratégico na mobilização e coordenação, respondendo pela concertação das ações de promoção da igualdade racial, adotando as definições estratégicas da transversalidade, intersetorialidade e interseccionalidade. ${ }^{20}$

Essa política, por se tratar de matéria nova no que diz respeito a gestão, traduziu-se em um desafio suplementar quanto a capacitação dos gestores públicos para lidar, sobretudo, com a dimensão da transversalidade da política, princípio adotado pelo Ministério do Planejamento. Ao estabelecer as diretrizes de planejamento, foi necessário a combinação das políticas de natureza mais gerais e suas interfaces com as políticas de promoção da igualdade racial.

Seu foco prioritário inicial, tendo como indicação primordial a redução das desigualdades raciais no Brasil, esteve centrado nos eixos temáticos relacionados ao apoio à política quilombola, à adoção de políticas de ações afirmativas, a programas de incentivo à diversidade racial no mercado do trabalho e ao desenvolvimento de programas de atenção à saúde da população negra.

Esses ajustes se configuraram em importantes passos para mudanças quanto ao "lócus" da política, ao sair do campo da violação de direitos humanos, o que muda o seu referencial. Ao desvincular a política racial enquanto política de Estado, vinculada ao Ministério da Justiça em especial a Secretaria de Estado dos Direitos Humanos, eleva-se a sua dimensão, saindo do campo reativo penal (política de combate ao racismo) para a dimensão promocional, mais afeita à política que importa ao Estado brasileiro.

${ }^{20}$ Os conceitos de intersetorialidade, interseccionalidade e transversalidade na gestão pública não são sinônimos. Contudo eles se referem à mesma concepção: de que as políticas públicas devem se articular para contribuir, sobretudo, para a superação das desigualdades econômicas, de gênero e raça/etnia. 


\section{PLANO NACIONAL E CONFERÊNCIAS}

O Plano Nacional de Promoção da Igualdade Racial (PLANAPIR) indica ao Estado as metas para superar as desigualdades raciais existentes no Brasil, por meio da adoção de ações afirmativas associadas às políticas universais.

Aprovado pelo Decreto № 6.872/2009, o PLANAPIR foi idealizado em 2005, com base nas propostas apresentadas na I Conferência Nacional de Promoção da Igualdade Racial. Efetivamente o Plano procura garantir o recorte étnico-racial no conjunto das políticas públicas executadas pelo governo, seguindo os princípios da transversalidade, descentralização e gestão democrática.

Define ainda as principais estratégias para a efetivação da Política de Promoção da Igualdade racial, com a consolidação dos seguintes instrumentos:

a) Conselho Nacional Combate à Discriminação - CNCD

A criação, em 2001, do Conselho Nacional de Combate à Discriminação (CNCD), à época vinculado à Secretaria de Estado dos Direitos Humanos, do Ministério da Justiça e, atualmente, integrando a Secretaria Especial de Direitos Humanos, da Presidência da República, já prenunciava uma necessidade de institucionalização das demandas sociais em uma instância especifica para tratar a questão da discriminação.

O Conselho tem entre seus objetivos o incentivo à criação de políticas públicas afirmativas de promoção da igualdade e de proteção dos direitos de indivíduos e de grupos sociais, raciais e étnicos que sejam objeto de discriminação racial ou de outras formas de intolerância.

b) Conselho Nacional de Promoção da Igualdade Racial - CNPIR

No mesmo ano de criação da Seppir (2003), foi criado Conselho Nacional de Promoção da Igualdade Racial (CNPIR), e lançada a Política 
Nacional de Promoção da Igualdade Racial. O CNPIR, criado pelo Decreto no 4.885, é órgão colegiado de caráter consultivo vinculado à Seppir e tem como missão propor políticas de combate ao racismo e ao preconceito.

Este órgão é composto por 20 representantes da sociedade civil, 17 representantes de ministérios e três personalidades reconhecidas, e é presidido pelo titular da Seppir.

c) Fórum Intergovernamental de Promoção da Igualdade Racial - FIPIR

Outra importante iniciativa de mobilização empreendida pela Secretaria foi a instituição do Fórum Intergovernamental de Promoção da Igualdade Racial (Fipir), que reúne municípios e estados que possuem organismos executivos voltados para a questão racial, como secretarias, coordenadorias, assessorias e estruturas afins.

O objetivo do Fipir é articular esforços nos três níveis de governo para a implementação de políticas de promoção da igualdade racial, uma vez que somente com o envolvimento dos demais entes federativos tal agenda pode encontrar respaldo e ser efetivada, atingindo a totalidade da população foco dessa atuação.

A efetivação desses instrumentos de participação objetiva aproximar 0 diálogo entre Estado e sociedade nos três níveis da Federação. Decorridos treze anos após a criação da SEPPIR, a Política de Promoção da Igualdade racial, neste breve espaço de tempo, vai aos poucos se consolidando enquanto um desafio para a governabilidade com base em critérios de participação e representação da pauta racial.

Neste sentido, cabe avaliar o grau de pertinência quanto aos propósitos estabelecidos e os resultados que se depreende deste esforço, ao redefinir padrões de participação deste segmento a partir do novo desenho institucional. Para sua efetivação, a realização das conferências nacionais de promoção da igualdade racial é o espaço de maior relevância quanto a ampliar sua representação em caráter nacional, fortalecendo assim as instâncias receptoras formais de ligação entre Estado e sociedade. 
Com vistas a avaliar o papel primordial das conferências de promoção de igualdade racial enquanto espaços privilegiados de disputa quanto às estratégias adequadas de formular, propor e deliberar sobre políticas públicas dentro do recorte racial, buscando a transversalidade no âmbito das políticas setoriais, urge, pois examinar o papel das três conferências, ocorridas em 2005 (I Conapir), 2009 (II Conapir) e 2013 (III Conapir).

A realização dessas conferências estabeleceu um marco inaugural na política de promoção da igualdade racial, por possibilitar de maneira ampliada o debate em torno da institucionalidade da política, bem como a capilaridade das ações da SEPPIR.

Se no processo que antecede a realização das conferências a mobilização se dava através de ações pontuais, com base nas articulações de grupos específicos com maior proximidade do Governo, com a realização da primeira conferência a participação assume um caráter consultivo, cujas deliberações buscaram a formação de consensos em torno de pontos convergentes na elaboração do Plano nacional de promoção da igualdade racial.

O repertório das representações políticas do Movimento negro, a exemplo do que ocorreu na primeira ação de mobilização de impacto nacional com o I Encontro Nacional de Entidades Negras(1991), irá proporcionar uma visão panorâmica da diversidade de organizações e orientações ideológicas e política dessas representações.

Com efeito, cabe destacar que as diversas formas de expressão dos segmentos dessas organizações políticas cumprem dois papeis importantes quanto sua atuação no âmbito da política: de um lado, sinalizam a amplitude das demandas voltadas para a população negra; de outro, enfatizam os desafios de mudanças quanto a natureza da democracia representativa.

As especificidades das organizações efetivamente pressupõem um diálogo nem sempre tranquilo com as instituições formais do Estado, uma vez que as conferências cumprem um objetivo central na elaboração de diretrizes para a formulação de políticas públicas, tornando-se assim impulsionadoras dos processos de institucionalização da temática racial no âmbito legislativo e, também, no executivo. 
A I Conferência Nacional de Promoção da Igualdade Racial - I CONAPIR, tendo como sua principal expectativa traçar as linhas gerais para a elaboração de um plano de ação para fortalecer as ações do Estado brasileiro no enfrentamento das desigualdades étnico-raciais e as consequências do racismo, partiu da consequente necessidade de impactar a formação a agenda do poder executivo a partir da SEPPIR.

Com a realização da I CONAPIR, o processo de elaboração e formulação de políticas específicas irá exigir a instrumentalidade necessária às demandas propostas oriundas desta conferência, com o intuito de incorporação às políticas constitucionalmente garantidas. A transversalidade do tema passa a requerer um plano de ação que dialogue com as diversas instâncias de governo, traduzindo assim uma agenda propositiva junto aos órgãos executores, tendo a SEPPPIR enquanto órgão coordenador da política.

A I CONAPIR representou um marco na política governamental orientada para o diálogo efetivo entre Estado e sociedade, consagrando uma ação de Estado capaz de recepcionar as elaborações históricas da luta contra as desigualdades étnico-raciais.

Ao tempo em que revelou uma enorme perspectiva de ampliação do processo democrático nacional, adotando como tema central da referida Conferência "Estado e Sociedade Promovendo a lgualdade Racial", I CONAPIR possibilitou também perceber os limites estruturais para o pleno cumprimento desta incorporação.

A magnitude das desigualdades étnico-raciais e sua complexa composição quanto as representações dos grupos etnicamente discriminados - quais sejam, negros, indígenas, ciganos, entre outros segmentos representou um desafio inovador na promoção do diálogo entre Governo e sociedade.

Sendo assim, o Decreto № 4.886, de 20 de novembro de 2003 - da Política Nacional de Promoção da Igualdade Racial - PNPIR, constituiu-se em um marco regulatório primordial para as ações de Governo, amparado nos princípios que regem a execução da política para a SEPPIR: transversalidade, gestão democrática e descentralização.

Concomitante à PNPIR, também foi publicado o Decreto № 4.885, de 20 de novembro de 2003 - do Conselho Nacional de Promoção da Igualdade 
Racial21- CNPIR, com a função de dar suporte às estratégias de gestão democrática. Composto por representantes da sociedade civil e governamentais, o propósito do CNPIR é a construção dos parâmetros da política de promoção da igualdade racial.

Com a realização da II Conferência Nacional de Promoção da Igualdade Racial, os principais objetivos foram analisar as diretrizes aprovadas na I Conapir, sobretudo avaliar a implementação da Política Nacional de Promoção da Igualdade Racial, cujo desafio maior é articular as políticas setoriais universalistas com as políticas transversais de promoção da igualdade racial.

No entanto, o que se pode depreender é que dado à magnitude das peculiaridades de que se revestem essas demandas políticas, o processo de pactuação requer um ajuste necessário à atuação do poder executivo, bem como do poder legislativo.

A partir da II Conapir, a elaboração e aprovação do Plano Nacional de Promoção da Igualdade Racial - Planapir, aprovado por Decreto n 6872 , em 04 de junho de 2009, cumpre a função impulsionadora de alargar os espaços de participação, passando estes a contar com mecanismos mais abrangentes para a estimulação das organizações em suas mais variadas configurações, de grupos sociais a grupos culturais espalhados pelo país.

Como consequência, a instituição do Comitê de Articulação e Monitoramento, em setembro do mesmo ano, buscou efetivar a necessária articulação entre as representações de governo no âmbito de 15 ministérios $^{22} \mathrm{e}$

${ }^{2121}$ O CNPIR é um órgão colegiado de caráter consultivo e integrante da estrutura básica da SEPPIR. O CNPIR foi criado pela Lei no 10.678, de 23 de maio de 2003, e regulamentado pelo Decreto no 4.885 , de 20 de novembro de 2003, com alterações feitas pelo Decreto no 6.509 , de 16 de julho de 2008, os quais dispõem sobre a composição, estruturação, competências e funcionamento do conselho.Fonte<http://www.ipea.gov.br/agencia/images/stories/PDFs/relatoriopesquisa/120409 _relatorio_igualdade_racial.pdf acessado em 15/09/2014

${ }^{22}$ Comitê de Articulação e Monitoramento - Composição: 15 Representantes do Governo e três da sociedade civis indicados pelo Conselho Nacional de Promoção da Igualdade Racial - CNPIR, Órgão consultivo integrante da SEPPIR. Sob coordenação da SEPPIR, o comitê tem atuação transversal no governo e conta com a participação dos seguintes órgãos: Secretaria Geral da Presidência da República; Secretaria Especial dos Direitos Humanos; Secretaria Especial de Políticas para as Mulheres; Ministério da Justiça; Ministério da Saúde; Ministério das Cidades; Ministério do Desenvolvimento Agrário; Ministério do Desenvolvimento Social e Combate a fome; Ministério do Planejamento, Orçamento e Gestão; Ministério do Trabalho e Emprego; Ministério da Cultura; Ministério de Minas e Energia. 
três representações da sociedade civil indicadas pelo Conselho Nacional de Promoção da Igualdade Racial, com a tarefa de propor ações, estabelecer metas, buscando monitorar, acompanhar e avaliar as atividades concernentes a política de promoção da igualdade racial.

A realização da III Conapir ocorreu em meio a uma profusão de aspectos marcantes na conjuntura do país, das mobilizações nas ruas em junho na luta por serviços sociais básicos passando a situações explicitas do racismo nacional, com homens e mulheres negras sendo vitimados pela violência policial e pela omissão do Estado, e a contextos de avanços no campo institucional, como a confirmação por unanimidade pela Corte Suprema da legalidade do sistema de cotas para negros nas universidades públicas do país.

Fator de grande relevância é o marco de dez anos da política de promoção da igualdade racial, momento propício para uma profunda avaliação dos impactos dessa política, bem como os impasses e desafios para a consolidação desta política.

O tema da conferência, Democracia e Desenvolvimento sem Racismo: por um Brasil Afirmativo, suscitou questões mediadas pela conjuntura quanto aos avanços da institucionalização da política, ao tempo em que revelou os limites dessa mesma política. Os eventos relacionados ao racismo brasileiro têm se evidenciado como uma prática culturalmente arraigada nas estruturas da formação social.

Ainda que mensurações sobre os avanços da referida política sejam relevantes quanto a sua ampliação e incidência nas pautas governamentais, com a incorporação de novas perspectivas de gestão da política inclusiva, estão em disputa de projetos políticos decorrentes de contextos históricos que remontam ao período da colonização escravocrata e até aos novos arranjos para a política de desenvolvimento com a inserção de grupos historicamente postos a margem do processo das políticas universalistas.

OS DESAFIOS PARA A INSERÇÃO DA POLÍTICA DE PROMOÇÃO DA IGUALDADE RACIAL 
A fragmentação e as fragilidades com que se vêm traduzindo as ações governamentais na consolidação dos processos de planejamento e gestão da referida política revelam ambiguidades. Por um lado, quanto ao reconhecimento da existência das desigualdades raciais no Brasil e pela identificação destas desigualdades como o cerne da problemática social brasileira. Por outro, não se percebe uma efetiva disposição de fazer 0 enfrentamento do tema mediante mecanismos institucionais através de políticas públicas dotadas de um conjunto organizado, sistemático e coordenado de iniciativas articuladas intersetorialmente.

Diante do quadro, as questões do financiamento das ações e da definição de estratégias para assegurar recursos nos diferentes ministérios e secretarias têm se constituído em critérios de cunho carismático sem uma clara atribuição formal institucional e sem definição de previsão e execução orçamentária de cada ação.

Para uma melhor explicitação dos obstáculos observados nos processos de planejamento setoriais da política em tela, observemos os mecanismos balizadores da ação do Estado.

Segundo a Constituição Federal, art. 65, as linhas mestras da ação governamental federal, no Brasil, devem estar expressas nos seguintes instrumentos: o Plano Plurianual (PPA); a Lei de Diretrizes Orçamentárias (LDO); e a Lei Orçamentária Anual (LOA).

Esses mecanismos institucionais respondem por um complexo conjunto de objetivos conformando o sistema de planejamento do Poder Executivo, devendo ser submetidos à aprovação do Congresso Nacional.

O PPA tem duração quadrienal. Lá estão as principais linhas de ação governamentais, que, no caso, foram estabelecidas a partir da definição de três mega-objetivos: 1: inclusão social e redução das desigualdades sociais; 2: crescimento com geração de emprego e renda, ambientalmente sustentável e com redução das desigualdades regionais e; 3: promoção e expansão da cidadania e fortalecimento da democracia.

Nesse trabalho, nos propomos apenas a elencar os desafios que as políticas de promoção da igualdade racial têm que enfrentar para se consolidar 
enquanto políticas capazes de reversão da realidade de pobreza e desigualdades.

Os três mega-objetivos do Plano Plurianual Anual expressam em síntese os desafios com os quais a dimensão da política racial se insere na macrogestão da política de governo:

1. Mega-objetivo $\mathrm{n}^{\circ} 01$

$\checkmark$ Combater a fome e promover segurança alimentar e nutricional, garantindo a inserção social e a cidadania;

$\checkmark$ Promover 0 acesso universal, com qualidade à seguridade social (saúde, previdência e assistência) e a educação;

$\checkmark$ Ampliar a transferência de renda e aprimorar os seus mecanismos;

$\checkmark$ Promover o aumento da produção e a redução dos preços de bens e consumo popular;

$\checkmark$ Promover a redução da vulnerabilidade das crianças e dos adolescentes em relação a marginalização e ao crime;

$\checkmark$ Democratizar e universalizar $o$ acesso à informação e ao conhecimento por meio das novas tecnologias;

2. Mega-objetivo oㅜ 02

$\checkmark$ Ampliar a oferta de postos de trabalho, promover a qualificação dos trabalhadores e regular o mercado de trabalho, com ênfase na redução da informalidade;

$\checkmark$ Reduzir as desigualdades regionais com integração das múltiplas escalas espaciais (nacional, macrorregional, sub-regional e local);

3. Mega-objetivo oㅜ 03

$\checkmark$ Promoção e expansão da cidadania e fortalecimento da democracia.

O conjunto de objetivos acima elencados teve sua formulação no Plano Plurianual 2004- 2007 (PPA), elemento-chave da política do então governo Luiz Inácio Lula da Silva, estabelecendo assim um instrumento capaz de 
dialogar através dos instrumentos de gestão, mediante um amplo canal de comunicação com o conjunto da sociedade, em todo o país.

Cada um dos mega-objetivos foi decomposto em desafios. Ao todo, foram estabelecidos 31 desafios, dentre os quais, o de no 8 , ligado ao Megaobjetivos 1, que interessa mais de perto a este trabalho: "promover a redução das desigualdades raciais, com ênfase na valorização cultural das etnias". O desafio $n^{\circ} 8$ apresenta os seguintes desdobramentos em termos de diretrizes:

- Definir políticas direcionadas para a redução das desigualdades raciais, ao combate à discriminação e ao preconceito racial;

- $\quad$ Promover políticas de ação afirmativa;

- Promover a equalização do acesso aos serviços públicos e aos direitos sociais básicos, tendo em vista o corte racial;

- Apoiar, ampliar e aperfeiçoar a cogestão, parcerias e controle social com as organizações da sociedade civil;

- $\quad$ Envolver a população, grupos vulneráveis e organizações na elaboração das políticas e implementação dos projetos;

- Implementar políticas de promoção que garantam a igualdade racial e condições de trabalho iguais independentemente de raça e estrato social.

O segundo balizador, a LDO, também tem suas atribuições definidas no texto constitucional: deve apresentar as metas e prioridades anuais da administração pública federal; orientar a elaboração da lei orçamentária anual; dispor sobre as alterações na legislação tributária; e estabelecer a política de aplicação das agências financeiras oficiais de fomento (CF, art. $165 \S 2^{\circ}$ ).

É a LDO, portanto, que vai estabelecer as bases da lei orçamentária do ano seguinte, funcionando como uma espécie de elo entre o PPA e o Orçamento.

Tomando-se o exemplo da LDO sancionada em dezembro de 2006, temse, em seu Art. 1으 o seguinte: 
São estabelecidas, em cumprimento ao disposto no art. 165 , $\S 2^{\circ}$, da Constituição, e na Lei Complementar no 101, de 4 de maio de 2000, as diretrizes orçamentárias da União para 2007, compreendendo:

I - as prioridades e metas da Administração Pública Federal;

II - a estrutura e organização dos orçamentos;

III - as diretrizes para a elaboração e execução dos Orçamentos da União e suas alterações;

IV - as disposições relativas à dívida pública federal;

$\mathrm{V}$ - as disposições relativas às despesas da União com pessoal e encargos sociais;

VI - a política de aplicação dos recursos das agências financeiras oficiais de fomento; da União;

VII - as disposições sobre alterações na legislação tributária

VIII - as disposições sobre a fiscalização pelo Poder Legislativo e sobre as obras e serviços com indícios de irregularidades graves; $\mathrm{e}$

IX - as disposições gerais.

Tem-se assim, com a LDO, o roteiro básico a ser seguido pela Lei Orçamentária Anual (LOA).

A LOA é, de fato, a peça orçamentária na qual estão previstos os programas e as ações, assim como os desembolsos respectivos. Lá estão inscritas, de fato, as prioridades do governo. De acordo com a Constituição Federal, o orçamento deve ser desmembrado em três: o orçamento fiscal; o orçamento de investimento das empresas; e o orçamento da seguridade.

$\mathrm{Na}$ prática, apenas os dois primeiros orçamentos existem de fato. Já o terceiro, referente à seguridade social, em função da própria segmentação, independência e autonomia das três áreas que o compõem (saúde, assistência social e previdência social), tem uma existência meramente contábil, o que certamente vem desvirtuar a perspectiva de política social inscrita na Carta Magna. De todo modo, a LOA estabelece o horizonte e os limites da ação governamental, assim como suas prioridades e perspectivas.

Para um balizamento dessa análise, Theodoro (2011) asseverava:

[...] Com efeito, nesses três anos de vigência do PPA 2003-2007, o que se pode observar é que, de um modo geral, a despeito das diretrizes anuais inscritas nas respectivas LDO, as ações propostas 
nas LOA, no que tange à problemática racial, têm sido pontuais e as metas a elas associadas não se colocaram efetivamente à altura do desafio de "reduzir as desigualdades raciais no país". No caso do

Programa "Gestão da Política de Promoção da Igualdade Racial", governo disponibilizou, anualmente, menos de $\mathrm{R} \$ 20$ milhões. Muito pouco para o que seria o principal instrumento do desafio de redução das desigualdades raciais.

É importante ressaltar que não está previsto, nas LDO ou nas LOA dos últimos anos, qualquer programa setorial que tenha por objetivo 0 combate às desigualdades raciais e suas causas. E sem programas, não há indicadores que permitam o acompanhamento das ações públicas. (THEODORO, 2011, p. 9).

A Política de Promoção de Igualdade Racial foi apresentada como diretriz nos dois últimos Planos Plurianuais. No PPA 2003-2007, a estratégia de governo estava direcionada para a inclusão social e desconcentração de renda, por meio da dinamização do mercado de consumo de massa. As iniciativas que dariam forma a essa estratégia distribuíam em cinco dimensões: social, econômica, regional, ambiental e democrática, que se articulavam em torno de mega-objetivos, desdobrados em desafios a serem enfrentados por meio de programas compostos por ações conforme dispositivo normativo.

Tal desafio somente se desdobrou em dois programas, a saber: o da "Gestão da Política de Igualdade Racial" e o programa voltado às comunidades remanescentes de quilombos, o "Brasil Quilombola".

O primeiro programa citado apresenta limites importantes, pois de acordo com o PPA, os programas de gestão não preveem a adoção de indicadores. Tais indicadores estão associados apenas aos programas finalísticos que são definidos setorialmente. Porém, como o desafio "redução da desigualdade racial" não foi desmembrado em programas e/ou ações nos diferentes ministérios setoriais, não se constata uma concreta ação multissetorial para se enfrentar as desigualdades raciais no Brasil. Desta forma, como não houve envolvimento efetivo dos demais ministérios na consecução de uma linha política de promoção da igualdade racial, ou seja, face à ausência de programas setoriais, não foram previstos indicadores que balizassem, nas diferentes áreas, os resultados do programa e de suas ações. 
O programa Brasil Quilombola, que teve por objetivo "coordenar as ações governamentais para as comunidades remanescentes de quilombo por meio de articulações transversais, setoriais e interinstitucionais, com ênfase na participação da sociedade civil", tornou-se o principal programa do governo federal no que tange a políticas direcionadas à população negra.

Dada limitada política governamental para a população negra, ainda que expressa a manifestação das intenções políticas de criação de uma Secretaria com status de Ministério, que mais tarde veio a se efetivar enquanto Ministério, muito mais para adequação institucional, as intenções não significaram mudanças estruturais quanto a realidade para o qual a Secretaria fora criada.

\section{LIMITAÇÕES DO NEODESENVOLVIMENTISMO}

O caminho até aqui percorrido possibilitou avançar no alargamento dos espaços de representação e identidade, todavia, muito se há ainda a lastrear o caminho, sobretudo na reconstrução de uma ordem social equitativa e livre do racismo, pedra angular das desigualdades no Brasil.

Todavia, os arranjos institucionais adotados na adoção de políticas de promoção da igualdade racial não devem ser vistos como a solução de integração da referida política na agenda pública.

A complexidade e amplitude de que se reveste essa política não poderia se resumir a uma simples incorporação de matéria nova no tocante a uma dimensão a ser inserida no conjunto das demais políticas. Ainda que se reconheçam os avanços preconizados com a institucionalidade, é mister que se avaliem as exigências de acomodação entre políticas econômicas com forte viés econômico desenvolvimentista ${ }^{23}$ e políticas sociais.

\footnotetext{
${ }^{23}$ De acordo com Cepêda (2012, p.79), o desenvolvimentismo nasce de uma constatação de deficiência estrutural e crônica como base lógica de intervenção tendo o objetivo de transformação. É em síntese um projeto de transformação social profundo operado politicamente de maneira racional e orientado pelo Estado, vinculando economia e avanço social.
} 
As escolhas pela adoção de um modelo neodesenvolvimentista, ${ }^{24}$ no governo Lula, traduziram-se em desafios adicionais por se tratar de opção heterogênea de fomento a política de crescimento econômico e transferência de renda, como forma de mitigar desigualdades historicamente observadas.

O debate das questões raciais ainda não se efetivou enquanto uma demanda a ser considerada no interior da sociedade brasileira. Dentro da lógica do desenvolvimento, há uma tênue sinalização de que esse tema, quando evidenciado, traz consigo uma marca do passado que precisa ser esquecido.

Com isso o que poderia conter um forte teor político na política racial passa a ser um ônus complementar ao debate em torno da pobreza. Com isso, inverte-se a lógica de que o processo civilizatório determinou o lugar desse segmento com a anuência do Estado, que agora se coloca diante do problema percebendo a magnitude e o custo da escravidão e da negação de direitos para a população negra.

A política de proteção social, quando acionada, torna-se irrelevante, tal a dimensão com o que outrora era um problema localizado atualmente assume como uma questão social em aberto na sociedade brasileira.

Desta forma, com efeito, o maior desafio está ao enfrentar a questão racial, desfazer os autoenganos nacionais ao lidar com o tema como se ele fosse menor do que se apresenta; por outro lado, buscar alcançar a dimensão que as demandas em torno das políticas sociais assumiram, para esse contingente populacional não minoritário.

São visíveis os limites com que os dois últimos governos tentaram equacionar do tema de forma pontual e emergencial. As diversas tentativas de se promover políticas pontuais em torno da questão racial - aqui, citando as duas últimas tentativas quer do Governo FHC e ou do Governo Lula -, sinalizações pontuais de longe, não poderiam servir de contraponto as exigências das políticas desenvolvimentistas que esses governos assumiram.

\footnotetext{
${ }^{24}$ Para Boito $(2012$, p.6), o neodesenvolvimentismo tem um sentido mais adequado as exigências do capitalismo neoliberal. Segundo o autor, é uma nova roupagem do neoliberalismo sob o qual os limites de uma política de desenvolvimento está atrelada a lógica do capital internacional atuando como elemento de pressão dos países imperialistas sobre as economias dependentes e dos capitalistas sobre a classe trabalhadora.
} 
Guardadas as devidas proporções, quanto à inovação que a questão racial traz, o que nos parece comum aos dois governos é a forma de tratar essa questão como indissociável do modelo originário de um capitalismo periférico, atualizado pelo padrão de regulação social, não mais pela via do trabalho, mas pela via da renda (COHN, 2000, p.185).

A política de promoção da igualdade racial, quando vista a partir das diretrizes da macroeconomia, insere-se nas especificidades das políticas de proteção social de reduzido escopo.

Isso, evidentemente implica na classificação de uma política de caráter temporal e limitada, devendo assumir sua perspectiva de política de governo, escalonada no tempo e no espaço. Frágil e atacável, essa política tem ainda como aliado a negação do racismo como agravante.

Exemplo disso é que tanto no governo FHC quanto no de Lula, e mais recentemente no governo Dilma, em todos os momentos em que se pensa na redução de gastos, as primeiras inciativas advêm de setores inconformados com a criação dessa nova institucionalidade da política racial:

[...] a tendência, é exatamente a de conformar no país um sistema dual de proteção social, entendendo se por sistema de proteção social todo conjunto de políticas sociais (aí incluída a previdência social), com distintas lógicas na sua articulação com a dinâmica macroeconômica. De um lado, o subsistema de proteção social relativo aos benefícios sociais securitários - e, portanto, contributivos; de outro, o subsistema relativo aos benefícios sociais assistenciais e portanto, redistributivos, financiado com recursos do orçamento fiscal. (COHN, 2000, p.186)

A Secretaria Especial de Promoção da Igualdade Racial, em seus 12 anos de criação, tem um problema de difícil solução que é caracterizar sua identidade uma importante secretaria na formulação das políticas sociais. Seu escopo focalista serve de argumento para reduzir sua abrangência enquanto formuladora de uma política de Estado, estando sempre a reboque das dimensões governamentais do momento.

Este órgão passou a compor o conjunto de pastas que tem 0 compromisso de traçar diretrizes para a política de promoção da igualdade racial. No entanto é importante ressaltar que se trata de uma secretaria com status de ministério, porém sem dotação adequada a magnitude de suas tarefas. 
O que se pode observar é que, sendo seu escopo de ação adstrito a concertações com os demais ministérios, são identificados uma série de problemas, entre os quais o quadro diminuto de pessoal permanente e a falta de capacidade gerencial sobretudo no que diz respeito as ações afeitas a referida pasta.

Se por um lado são percebidos esses obstáculos, há um determinado obstáculo que merece maior atenção. Na composição do segmento que dispõe de meios para ingressar nos concursos públicos, a maioria significativa compõe o substrato mais resistente a integração racial. Nesse sentido, as ações de coordenação das políticas raciais são, via de regra, obstruídas pela pretensa discricionariedade arbitrária (não havendo prescrição, mas uma posição de caráter pessoal), corroborando o racismo institucional.

A perspectiva de consolidação da política de promoção da igualdade racial na atual conjuntura carece de uma profunda revisão, sobretudo no que concerne ao conjunto de lacunas nas programações e diretrizes do Plano Plurianual; à ausência de indicadores, para o público-alvo e mesmo na descrição dos objetivos das ações; e, não menos grave, a não vinculação de recursos para políticas voltadas a esse segmento da população.

Indefinições, falta de recursos, inexistência de programas e ações setoriais consolidadas nos instrumentos de planejamento de governo consubstanciam uma falta de identidade da máquina governamental com relação ao desafio de redução da desigualdade racial.

A Secretaria de Políticas de Promoção da Igualdade racial - SEPPIR, enquanto órgão coordenador da política ainda não conseguiu ao que parece traçar estratégias para além das aproximações carismáticas cujo limite fica a cargo da simpatia do gestor da pasta, isso contraria frontalmente os instrumentos de acompanhamento da ação pública adequadas às práticas de natureza transversal e multissetorial.

As diretrizes foram postas; uma secretaria foi criada, mas sem que seus objetivos se espelhassem no planejamento anual do governo e sem que programas e ações se efetivassem.

No entanto, podem-se observar avanços quanto à compreensão do fenômeno do racismo enquanto um poderoso elemento estruturante das relações sociais, políticas e culturais e seus impactos mais gerais para a 
consolidação da democracia e equidade. Todavia, apesar do forte apelo que o tema enseja na consagração de processos emancipatórios, ainda é corrente as dificuldades de uma efetiva integração ${ }^{25}$ dessa pauta no âmbito das formulações das políticas.

Destaque-se a consolidação de um importante instrumento de gestão e controle social que foram realização as Conferências Nacionais de Promoção da Igualdade Racial (CONAPIR), as quais definiram as diretrizes para a elaboração de planos setoriais para a população negra: I) Plano Nacional de Implementação da Lei № 10.637/2003; II) Plano Nacional de Saúde Integral da População Negra; III) Agenda Social Quilombola e Programa Brasil Quilombola.

De acordo com Nota Técnica № 07 do Instituto de Pesquisa Econômica Aplicada (IPEA) (2011, p. 3):

[...] No entanto, a política de igualdade racial em curso ainda não conseguiu alçar essa temática à centralidade das estratégias de desenvolvimento nacional. $O$ fortalecimento da política depende em nível estratégico de mais apoio político, de forma a reposicioná-la como condicionante para o alcance do ideal nacional de justiça social e, complementarmente, em nível tático e operacional, é essencial que os mecanismos de planejamento e orçamento sejam coordenados de forma a considerar suas especificidades e apoiar sua adoção ativa pelos diversos campos de atuação governamental.

Destarte, no processo de consolidação dessas ações governamentais é fundamental a análise dos aspectos essenciais da política de promoção da igualdade racial no que concerne a reafirmação do compartilhamento das responsabilidades entre os diversos órgãos governamentais na implementação dessas políticas, bem como dar maior visibilidade às estratégias de planejamento e financiamento do órgão coordenador - Secretaria de Políticas de Promoção da Igualdade Racial (SEPPIR) - e demais membros institucionais da esfera governamental.

As exigências atuais de um modelo de gestão que sinalize na redução dessas desigualdades dependem de uma destinação de esforços na reversão dos processos históricos originários e das escolhas políticas que sempre

${ }^{25}$ Como já foi mencionado, importa enfatizar aqui os conceitos de incorporação e integração, sendo a incorporação estratégia pela qual questões relevantes para uma política são levadas em conta de maneira pontual, sem comprometimento com os aspectos estruturantes. Por outro lado, a integração se refere à efetivação de um processo pelo qual os temas relevantes, necessariamente, transversalizam a formulação de determinada política. 
privilegiaram a uma pequena parcela da elite, não por acaso majoritariamente branca.

Para tanto, o reconhecimento dessas disparidades diariamente explicitadas pelo aumento sistemático dos conflitos sociais é revelado pelo aumento da pobreza, da criminalidade, da violência, do homicídio de jovens e pela ausência de serviços e equipamentos públicos em determinados territórios.

A sobre-representação da população negra em todos os índices negativos, é fato inquestionável com e a partir dos indicadores sociais desde sempre. Isso por si só denota uma evidente correlação entre condições de vida e pertencimento étnico-racial.

Todavia o desafio está em correlacionar a questão racial e as desigualdades sociais. O papel efetivo da variável racial na produção das desigualdades representa um dos pilares centrais para a elaboração de políticas públicas.

A questão racial se impõe a nosso ver como um desafio a mais na interpretação dos aspectos que envolvem mercado e sociedade. Se outrora havia uma necessidade de se pensar a identidade nacional, no momento atual a dimensão do racismo se impõe como um componente a mais nessa equação.

O aparato institucional da democracia no capitalismo (se é que é possível) requer a superação da igualdade formal e a revisão moral do mérito vinculado as qualidades individuais, bem como de relações pretéritas e presentes baseadas no racismo.

Dessa forma, o período em que esse trabalho se realiza, atualiza os principais questionamentos quanto as mudanças pretendidas na formulação de políticas públicas e na consolidação de uma gestão de tipo novo. A ampliação para a esfera federal de mecanismos de gestão, requer a inclusão das demandas da sociedade organizadas na gestão pública. 
As reivindicações do Movimento Negro passaram a tomar forma de maneira mais incisiva a partir do momento em que aliados às palavras de ordem vieram os dados. As propaladas desigualdades raciais a que se referiam os reclamos da população negra sobre condições objetivas de vida, enquanto perduravam apenas nos pleitos desse segmento, eram vistas como algo pontual e transitório.

Segundo Paixão (2014, p.393), a ênfase dos estudos raciais em aspectos simbólicos e culturais os distanciou dos temas que poderiam sinalizar um olhar mais acurado sobre as "denúncias" do Movimento Negro. Enquanto o debate racial situou-se nas bordas das questões sociais, mantinha-se inalterada a percepção da prevalência do mito da democracia racial.

Com essa postergação temática, mesmo para os grupos e segmentos socialmente organizados mais próximos do $\mathrm{MN}$, o entendimento era de que a luta de classes prevalecia em detrimentos a outras como raça e gênero.

Por muito tempo as possibilidades de alianças entre os diversos segmentos políticos organizados jazeram calcinadas sob essa premissa. Novos estudos, todavia, propiciaram um olhar mais acurado sobre os velhos dilemas de se constituir uma nação seja pela incorporação cultural do conjunto de seus membros independente do pertencimento racial, seja pela amalgamação das expectativas sociais, econômicas e culturais dos mesmos.

Ainda segundo Paixão, (op.cit., p.394) a persistência das desigualdades tem uma base ideológica de sustentação que ele denomina de "a lenda da modernidade encantada", título de seu livro.

Nessa obra 0 autor explora questões relativas à construção do pensamento social brasileiro e a questão racial à luz das formulações de diversos pensadores, e alia nessa análise crítica, em contraponto a autores estrangeiros e nacionais, as incursões políticas do Movimento Negro Brasileiro. Importante destaque crítico é dado às contribuições de dois autores norteamericanos: 26

${ }^{26}$ Carl Degler escreveu dentre outros, o livro "Nem Branco, nem preto", publicado em 1971, no qual o autor faz uma distinção sobre a discriminação e o preconceito no Brasil, alegando uma flexibilidade capaz de incorporar, ainda que de forma subalterna, o mulato, restando uma rigidez maior em relação ao elemento negro. Harold Hoetink, autor do livro "Escravidão e relações raciais nas Américas", parte das seguintes formulações: o preconceito racial é inerente a toda sociedade multirracial, apenas seu tom e volume variam de acordo com a constelação de formas geradas pelo encontro social; e 
Nesse sentido, autores como Degler ou Hoetink, mesmo operando dentro de um raciocínio eu no limite poderia contribuir para reforçar a lógica de que no Brasil as relações raciais seriam mais abertas e tolerantes, não deixaram de apontar contrapontos que dificilmente permitiriam abordagens mais otimistas sobre 0 modelo. Especialmente se para o mesmo for apresentada a agenda de promoção da igualdade racial entre os indivíduos dos diferentes grupos de raça/cor que, definitivamente, jamais poderia ser alcançada, nem pela solução do branqueamento, nem pelo mero desenvolvimento das forças produtivas. (PAIXÃO, 2014, p.394)

Com efeito, nossa abordagem aqui procura sedimentar os rumos que as pesquisas tomaram na perspectiva de apontar dados quantitativos para superar as percepções subjetivas da condição da população negra.

Nesse sentido, já nos anos 1980, destacam-se dois importantes pesquisadores, Nelson do Valle e Silva e Carlos Hasenbalg, ${ }^{27}$ que deram o teor que persiste na atualidade no debate em torno da questão racial, utilizando os indicadores estatísticos como insumos importantes para contribuir com os estudos relacionados às desigualdades raciais. Essa inflexão irá mudar significativamente a forma de se olhar para a realidade social e a questão racial.

Com base no levantamento das fontes de dados estatísticos sobre a variável raça/cor, objetivando estabelecer metodologias classificatórias, a qualidade das bases de dados promoveu uma melhor avaliação das políticas públicas.

Esses trabalhos passaram a compor um amplo espectro de instrumentos para validar as demandas do Movimento Negro. As instituições de pesquisas e pesquisadores acadêmicos, ante a visibilidade estatística dada aos indicadores que confirmam de maneira contundente a condição em matéria de renda, trabalho, educação dentre outras, passaram a cultivar um novo "lócus" de pesquisa.

toda sociedade multirracial é racista na mesma escala em que seus mecanismos de seleção social e de mobilidade revelam preferências por alguns indivíduos em detrimento de outros.

${ }^{27}$ Nelson do Valle e Silva analisa cuidadosamente as características e mudanças na estratificação social brasileira com base em números e estatísticas através da metodologia quantitativa. Também utilizou esses modelo para auferir os investimentos em educação com ênfase nas relações raciais. Carlos Hasenbalg, em seus estudos, afirma que o modelo de racismo nacional é compatível com o desenvolvimento do capitalismo, confirmando a persistência da dominação racial com base em profundos estudos estatísticos. A contribuição dos dois pesquisadores, sobretudo nos anos 1980, foi elaborar um conjunto de estudos sobre as desigualdades raciais tomando como referência a renda, a educação, a ocupação, dentre outros temas. 
Na efervescência dos anos 1980, período conforme já sinalizado acima de profunda mobilização das forças sociais na consolidação do processo de abertura democrática, ressalta-se o papel das organizações negras a exigir do Estado a maior visibilidade de informações estatísticas que garantam o direito às informações sobre esses indicadores. A reintrodução da variável raça/cor nos questionários, a maior visibilidade das informações na Relação Anual de Informações Sociais - RAIS e Cadastro Geral de Empregados e Desempregados - CAGED passariam a compor instrumentais adicionais na luta racial.

Como marca emblemática desse momento, o $\mathrm{MN}$ propôs, em uma parceria com o IBGE, uma campanha em 1990, "Não deixe sua cor passar em branco, responda com bom senso". Estratégia que, segundo Paixão (2011, p.5), permitiu que no referido ano o levantamento censitário fizesse o peso relativo de pretos e pardos (negros) alcançar $47,4 \%$, tendo, portanto, um aumento de 2,6 pontos percentuais superior ao observado no censo de 1980.

Desta forma, consagrado o direito à visibilidade estatística, o $\mathrm{MN}$ passa a contar com um instrumento fundamental para explicitar de maneira concreta as demandas que, para além dos aspectos simbólicos e culturais, passaram a ser um reforço na análise da efetividade das políticas voltadas com foco específico à população negra, como podermos verificar a seguir, acompanhando alguns desses indicadores que atestam a pouca eficácia de políticas pontuais no decorrer do período em que as políticas marcadamente racialistas foram implementadas.

AS ASSIMETRIAS RACIAIS DE 1995 A 2013

Decorridos 20 anos da realização das Marcha Zumbi contra o Racismo, pela Cidadania e Pela Vida, realizada em 20 de novembro de 1995, a qual teve como objetivo denunciar a ausência de políticas públicas voltadas para a população negra, já dispomos de informação capaz de avaliar a evolução das assimetrias raciais pelo menos até 2013 . 
Como ilustração para esse trabalho, elencamos um conjunto de dados estatísticos para evidenciar que, para além das intenções governamentais, os resultados auferidos na implementação de políticas públicas voltadas para a população negra, ainda se mantêm distantes de alcançar padrões razoáveis de equidade.

Se antes havia uma invisibilidade estatística e o Movimento negro partia do empirismo, hoje com a profusão de dados com recortes étnicos-raciais já é possível constatar e explicitar a magnitude do problema.

A confirmação da pouca ou nenhuma eficácia das políticas implementadas sobretudo a partir de 1995, revela que, para além das ações pontuais, fragmentadas e emergenciais, as políticas governamentais não refletem mudanças estruturais que possibilitem a alteração das condições de vida da maioria da sociedade brasileira.

Constata-se que a progressiva inclusão do quesito raça /cor na declaração da população brasileira tem alterado de maneira positiva os estudos em torno das características demográficas e socioeconômicas, para avaliação e mensuração das ações governamentais.

Por outro lado, a publicidade e transparência desses dados permitem uma acesso cada vez mais amplo de pesquisadores e ativistas para a instrumentalização dos mesmos para o controle e debate em torno da pauta racial.

a) Rendimento Médio Mensal

Quadro 1 - Rendimento Médio Mensal de Todas as Fontes da População Ocupada de 16 anos ou mais de idade, por Sexo, segundo Cor/Raça e Localização do Domicílio - Brasil e Regiões, 1995 a 2013

\begin{tabular}{ccccc}
\hline \hline \multirow{2}{*}{ Cor/Raça } & Região e & \multicolumn{3}{c|}{ Total } \\
\cline { 3 - 5 } & Localização do Domicílio & $\mathbf{1 9 9 5}$ & $\mathbf{2 0 0 3}$ & $\mathbf{2 0 1 3}$ \\
\hline \hline \multirow{4}{*}{ Branca } & Brasil & $1.741,90$ & $1.511,30$ & $2.135,60$ \\
& Norte & $1.673,20$ & $1.269,80$ & $1.715,40$ \\
& Nordeste & $1.096,10$ & 961,1 & $1.525,00$ \\
& Sudeste & $2.044,00$ & $1.729,20$ & $2.361,20$ \\
& Sul & $1.476,50$ & $1.357,30$ & $1.989,20$ \\
& Centro-Oeste & $1.763,40$ & $1.751,80$ & $2.615,40$ \\
\cline { 3 - 5 } & Urbano & $2.005,90$ & $1.652,20$ & $2.275,40$ \\
\cline { 3 - 5 } Negra & Rural & 631,8 & 673,9 & $1.118,00$ \\
\hline \hline
\end{tabular}




\begin{tabular}{llccc} 
Norte & $1.073,40$ & 799,2 & $1.146,30$ \\
Nordeste & 592,8 & 539,5 & 952,7 \\
Sudeste & $1.023,50$ & 884 & $1.402,50$ \\
Sul & 835,9 & 779,8 & $1.329,00$ \\
Centro-Oeste & $1.007,60$ & 963,5 & $1.624,80$ \\
\hline Urbano & 992,1 & 838,5 & $1.353,40$ \\
Rural & 375,1 & 347,1 & 687,4 \\
\hline \hline
\end{tabular}

Fonte: IBGE/PNAD

Elaboração: IPEA/DISOC

*a população negra é composta por pretos e pardos set./2013

** rendimento de todas as fontes deflacionado com base no INPC, período de referência

O rendimento médio mensal, por incorporar todas as fontes de renda, é expressão da agregação do conjunto das políticas de transferência de renda, do incremento do salário mínimo e seus reflexos na renda do trabalho e nas aposentadorias.

No período de 1995 a 2013, há evidentes melhoras dos indicadores sociais e econômicos da população negra, com destaque para a trajetória iniciada a partir de 2003, nas regiões Norte e Nordeste, onde o peso relativo da população negra é mais elevado.

Porém, mesmo num período em que a política social teve nas políticas de transferência o elemento central para mitigar a pobreza e a extrema pobreza, percebe-se que a população negra, em 2013, possuía rendimento médio mensal inferior ao percebido pela população branca dez anos antes.

b) Rendimento Mensal Domiciliar

\begin{tabular}{|c|c|c|c|c|}
\hline \multirow[b]{2}{*}{ Cor/Raça } & \multirow{2}{*}{$\begin{array}{c}\text { Região e Localização do } \\
\text { Domicílio }\end{array}$} & \multicolumn{3}{|c|}{ Total } \\
\hline & & 1995 & 2003 & 2013 \\
\hline \multirow{8}{*}{ Branca } & Brasil & 878,6 & 822,6 & $1.252,80$ \\
\hline & Norte & 720,9 & 580,2 & 870,6 \\
\hline & Nordeste & 539,9 & 489,3 & 819,1 \\
\hline & Sudeste & $1.019,90$ & 936,4 & $1.398,10$ \\
\hline & Sul & 799,3 & 805,7 & $1.254,60$ \\
\hline & Centro-Oeste & 849,8 & 918,3 & $1.524,70$ \\
\hline & Urbano & 985,8 & 884,2 & $1.327,40$ \\
\hline & Rural & 347,1 & 393,8 & 687,9 \\
\hline \multirow{5}{*}{ Negra } & Brasil & 368,8 & 362,3 & 664,2 \\
\hline & Norte & 432,9 & 363,2 & 561,7 \\
\hline & Nordeste & 268,8 & 268,7 & 515,7 \\
\hline & Sudeste & 469,9 & 444,7 & 782,8 \\
\hline & Sul & 384 & 411,1 & 786,9 \\
\hline
\end{tabular}




\begin{tabular}{lccc}
\hline Centro-Oeste & 467 & 477,5 & 903,2 \\
\hline Urbano & 432,9 & 403,7 & 727,9 \\
\hline Rural & 183,8 & 189,8 & 393,1 \\
\hline Fonte: IBGE/PNAD & & & \\
\hline Elaboração: IPEA/DISOC & & & \\
*a população negra é composta por pretos e pardos & & \\
**rendimento mensal domiciliar per capita deflacionado com base no INPC, período
\end{tabular}
de referência set./2013

Quando considerado o rendimento mensal domiciliar per capita médio, em que o tamanho das famílias consegue expressar de forma mais precisa a desigualdade, percebe-se que a distância entre brancos e negros é ainda maior.

Em 2013, a população negra possui rendimento domiciliar médio per capita inferior ao rendimento da população branca em 1995. Mesmo em 2013, a população branca percebia quase o dobro da população negra.

c)

istribuição da população ocupada

A distribuição de negros e brancos no mundo do trabalho, considerada a partir da posição na ocupação, também apresentou pequenas melhoras. 0 percentual de negros no serviço público e entre empregados com carteira assinada cresceu no período 1995-2013, embora empregados sem carteira e conta própria, evidências de trabalho precário, representassem aproximadamente $40 \%$ da ocupação dos negros em 2013. Entre os brancos, o percentual de ocupados em condições precárias é menor, se comparado com os negros, embora também expressivo.

Quadro 3 - Distribuição Percentual da População Ocupada com 16 anos ou mais de idade, por Cor/Raça e Posição na Ocupação - Brasil, 1995, 2003 e 2013.

\begin{tabular}{|c|c|c|c|c|c|c|}
\hline \multirow[t]{2}{*}{ Posição na Ocupação } & \multicolumn{3}{|c|}{ Branca } & \multicolumn{3}{|c|}{ Negra } \\
\hline & 1995 & 2003 & 2013 & 1995 & 2003 & 2013 \\
\hline Funcionário Público/Militar & 7,9 & 7,6 & 8,4 & 6,1 & 5,9 & 6,6 \\
\hline $\begin{array}{l}\text { Empregado com Carteira } \\
\text { Assinada }\end{array}$ & 33,7 & 34,8 & 43,9 & 25,2 & 26,2 & 37,1 \\
\hline $\begin{array}{l}\text { Empregado sem Carteira } \\
\text { Assinada }\end{array}$ & 13 & 15,3 & 12,4 & 19,6 & 20,6 & 16,5 \\
\hline Conta Própria & 22,9 & 21,8 & 19,9 & 24,9 & 24 & 21,5 \\
\hline Empregador & 5,7 & 6 & 5,5 & 2,1 & 2,3 & 2,2 \\
\hline Empregada Doméstica & 5,8 & 6,1 & 5,2 & 9,2 & 9,6 & 8,1 \\
\hline Outros & 10,9 & 8,4 & 4,8 & 12,9 & 11,4 & 7,9 \\
\hline
\end{tabular}




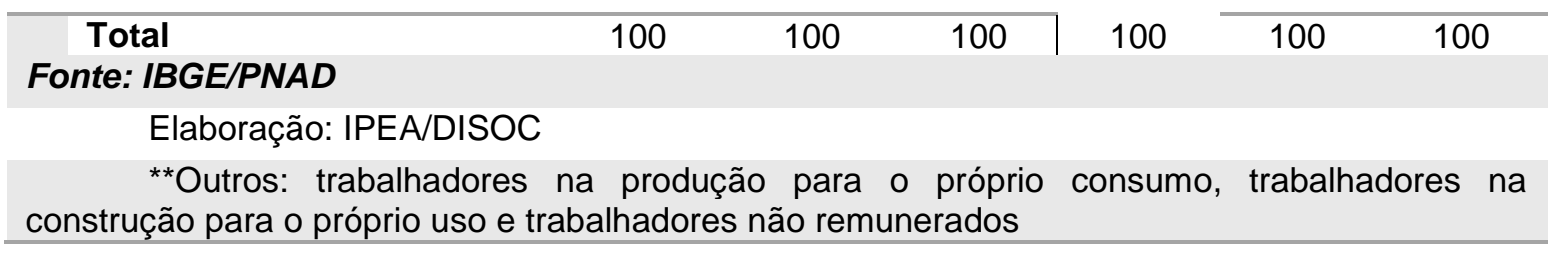

d) Taxa de desocupação

A taxa de desocupação também apresenta resultados díspares quando considerado o perfil racial da população brasileira. Os dados da PNAD apontam diferenças entre negros e brancos quanto a desocupação, sobretudo entre os jovens. Porém, a taxa de desocupação calculada pelo IBGE não inclui as pessoas desempregadas que pararam de procurar emprego - 0 desemprego oculto por desalento. Além disso, o IBGE considera como ocupados trabalhadores inseridos em condições precárias muito distantes dos padrões mínimos de dignidade.

\begin{tabular}{|c|c|c|c|c|c|c|}
\hline \multicolumn{7}{|c|}{$\begin{array}{c}\text { Quadro } 4 \text { - Taxa de desocupação da população de } 10 \text { anos ou mais de idade segundo } \\
\text { Cor/Raça, e Faixa Etária - Brasil, 1995, } 2003 \text { e } 2013\end{array}$} \\
\hline & \multicolumn{3}{|c|}{ Branca } & \multicolumn{3}{|c|}{ Negra } \\
\hline & 1995 & 2003 & 2013 & 1995 & 2003 & 2013 \\
\hline Total & 5,7 & 8,8 & 5,4 & 6,7 & 10,7 & 7,5 \\
\hline 10 a 15 anos & 10,8 & 15,7 & 19,1 & 9,4 & 12 & 14,6 \\
\hline 16 a 17 anos & 14,1 & 25 & 22,5 & 13,7 & 23,2 & 23,1 \\
\hline 18 a 24 anos & 10,2 & 16,9 & 11,5 & 11,2 & 19,2 & 15,2 \\
\hline 25 a 29 anos & 5,8 & 9,3 & 6,7 & 6,5 & 11,5 & 9,2 \\
\hline 30 a 44 anos & 3,9 & 6,1 & 4,1 & 4,8 & 8 & 5,8 \\
\hline 45 a 59 anos & 2,5 & 4,7 & 2,4 & 2,7 & 5,2 & 3,3 \\
\hline 60 anos ou mais & 1,3 & 2,5 & 1,8 & 1,7 & 3 & 2 \\
\hline
\end{tabular}

Fonte: IBGE/PNAD

Elaboração: IPEA/DISOC

**a taxa de desocupação é o quociente entre a população desocupada e a população economicamente ativa, na faixa etária determinada.

e) Rendimento médio mensal no trabalho principal

Quadro 5 - Rendimento Médio Mensal no Trabalho Principal da População Ocupada de 16 anos ou mais de idade, segundo Cor/Raça e Posição na Ocupação - Brasil, 1995, 2003 e 2013

\begin{tabular}{ccccc}
\hline \hline \multirow{2}{*}{ Cor/Raça } & \multirow{2}{*}{ Posição na Ocupação } & \multicolumn{3}{c}{ Total } \\
\cline { 3 - 4 } & & $\mathbf{1 9 9 5}$ & $\mathbf{2 0 0 3}$ & $\mathbf{2 0 1 3}$ \\
\hline \hline Branca & Total & $1.543,6$ & $1.324,1$ & $1.927,0$
\end{tabular}




\begin{tabular}{|c|c|c|c|c|}
\hline & Funcionário Público / Militar & $2.300,2$ & $2.175,2$ & $3.144,0$ \\
\hline & $\begin{array}{l}\text { Empregado/a com Carteira de } \\
\text { Trabalho Assinada }\end{array}$ & $1.733,2$ & $1.423,6$ & $1.820,3$ \\
\hline & $\begin{array}{l}\text { Empregado/a sem Carteira de } \\
\text { Trabalho Assinada }\end{array}$ & 938,7 & 854,0 & $1.350,5$ \\
\hline & Conta Própria & $1.524,6$ & $1.232,4$ & $1.810,1$ \\
\hline & Empregador/a & $5.006,2$ & $4.053,9$ & $5.704,8$ \\
\hline & Trabalhador/a Doméstico/a & 454,7 & 434,8 & 710,9 \\
\hline & Total & 737,1 & 645,5 & $1.101,5$ \\
\hline & Funcionário Público / Militar & $1.472,3$ & $1.429,8$ & $2.139,3$ \\
\hline & $\begin{array}{l}\text { Empregado/a com Carteira de } \\
\text { Trabalho Assinada }\end{array}$ & $1.012,8$ & 887,7 & $1.270,7$ \\
\hline Negra & $\begin{array}{l}\text { Empregado/a sem Carteira de } \\
\text { Trabalho Assinada }\end{array}$ & 513,7 & 497,1 & 872,6 \\
\hline & Conta Própria & 754,6 & 589,0 & $1.015,6$ \\
\hline & Empregador/a & $3.299,3$ & $2.209,9$ & $3.571,8$ \\
\hline & Trabalhador/a Doméstico/a & 380,4 & 361,2 & 614,5 \\
\hline
\end{tabular}

Fonte: IBGE/PNAD

Elaboração: IPEA/DISOC

* a PNAD não foi realizada nos anos de 2000 e 2010

** em 2004 a PNAD passa a contemplar a população rural de Rondônia, Acre, Amazonas, Roraima, Pará e Amapá

*** a população negra é composta por pretos e pardos

**** rendimento do trabalho principal deflacionado com base no INPC, período de referência set./2013

Quando considerada a estrutura social brasileira a partir da faixa de rendimentos, é possível visualizar a elevada participação dos negros na camada mais baixa, com 41,5\% da população negra ocupada recebendo até 1 salário mínimo no trabalho principal.

A despeito da inegável melhora dos rendimentos na série histórica, ela se deu na margem, concentrando mais de $90 \%$ da população negra nas faixas de rendimentos que não ultrapassam 3 salários mínimos.

Essa melhora também pode ser verificada nos indicadores associados à população branca, motivo pelo qual se pode inferir que, embora tenha ocorrido sensível melhora das condições de vida da população, a desigualdade racial permaneceu praticamente intocada.

Quadro 6 - Distribuição Percentual da População Ocupada de 16 anos ou mais de idade, por Sexo, segundo Cor/Raça e Faixa de Rendimento no Trabalho Principal - Brasil, 1995, 2003 e 2013.

\begin{tabular}{|c|c|c|}
\hline \multirow{2}{*}{ Cor/Raça } & \multirow{2}{*}{ Faixa de Rendimentos } & Total \\
\hline & & 2003 \\
\hline
\end{tabular}




\begin{tabular}{lllccc}
\hline & Até 1 SM & 46,6 & 50,1 & 23,6 \\
& Mais de 1 a 3 SM & 34,1 & 34,9 & 54,0 \\
& Mais de 3 a 5 SM & 9,4 & 8,1 & 10,2 \\
& Mais de 5 a 8 SM & 4,6 & 3,4 & 6,4 \\
& Mais de 8 SM & 5,3 & 3,5 & 5,8 \\
& Total & 100,0 & 100,0 & 100,0 \\
\hline \multirow{3}{*}{ Negranca } & Até 1 SM & 69,9 & 73,4 & 41,5 \\
& Mais de 1 a 3 SM & 23,7 & 22,4 & 49,3 \\
& Mais de 3 a 5 SM & 3,9 & 2,7 & 5,3 \\
& Mais de 5 a 8 SM & 1,5 & 0,9 & 2,4 \\
& Mais de 8 SM & 1,1 & 0,6 & 1,4 \\
& Total & 100,0 & 100,0 & 100,0 \\
\hline
\end{tabular}

Fonte: IBGE/PNAD

Elaboração: IPEA/DISOC

* a PNAD não foi realizada nos anos de 2000 e 2010

** em 2004 a PNAD passa a contemplar a população rural de Rondônia, Acre, Amazonas, Roraima, Pará e Amapá

*** a população negra é composta por pretos e pardos

${ }^{* * * *}$ rendimento do trabalho principal deflacionado com base no INPC, período de referência set./2013

\section{f) Educação}

Os indicadores relacionados ao acesso a direitos como educação, cobertura previdenciária e saneamento reforçam as profundas assimetrias ancoradas na reprodução permanente do racismo como um dos elementos estruturantes da sociedade brasileira.

A população negra com mais de 25 anos de idade com menos de um ano é muito superior ao peso da população branca com estas mesmas características.

\begin{tabular}{|c|c|c|c|c|c|c|c|}
\hline \multicolumn{8}{|c|}{$\begin{array}{c}\text { Quadro } 7 \text { - Proporção de pessoas de } 25 \text { anos ou mais de idade com menos de } 1 \text { ano de } \\
\text { estudo, por Cor/Raça, segundo Sexo - Brasil - 1995, } 2003 \text { e } 2013 \text {. }\end{array}$} \\
\hline \multirow[t]{2}{*}{ Região } & \multirow[t]{2}{*}{ Sexo } & \multicolumn{3}{|c|}{ Branca } & \multicolumn{3}{|c|}{ Negra } \\
\hline & & 1995 & 2003 & 2013 & 1995 & 2003 & 2013 \\
\hline \multirow[t]{3}{*}{ Brasil } & Total & 13,6 & 10,5 & 8,4 & 30,8 & 23,0 & 16,2 \\
\hline & Masculino & 12,6 & 9,9 & 8,2 & 30,7 & 23,2 & 16,8 \\
\hline & Feminino & 14,5 & 11,0 & 8,5 & 30,9 & 22,8 & 15,6 \\
\hline \multicolumn{8}{|c|}{ Fonte: IBGE/PNAD. } \\
\hline Elaboraç & IPEA/DISO & & & & & & \\
\hline
\end{tabular}

A taxa de escolarização líquida, que aponta a adequação ideal de idade/série, mostra que a população negra, além de possuir piores indicadores de escolarização formal, enfrenta mais dificuldades para percorrer a rota 
prevista no sistema de ensino, sobretudo a partir do ensino médio e do ensino superior, onde a universalização ainda não é uma realidade.

Quadro 8 - Taxa de Escolarização Líquida, por Sexo, segundo Cor/Raça e Nível de Ensino - Brasil, 1995, 2003 e 2013

\begin{tabular}{clccc}
\hline \hline \multirow{2}{*}{ Cor/Raça } & \multirow{2}{*}{ Nível de Ensino } & \multicolumn{3}{c}{ Total } \\
\cline { 3 - 5 } & Educação Infantil & $\mathbf{1 9 9 5}$ & $\mathbf{2 0 0 3}$ & $\mathbf{2 0 1 3}$ \\
\hline \multirow{4}{*}{ Branca } & $\mathbf{0}$ a 3 anos & $\mathbf{2 8 , 8}$ & 38,2 & 52,3 \\
& $\mathbf{4}$ a $\mathbf{6}$ anos & 5,7 & 12,9 & 26,2 \\
& Ensino Fundamental & 90,3 & 70,3 & 88,3 \\
& Ensino Médio & 32,1 & 95,0 & 96,2 \\
& Ensino Superior & 9,1 & 16,6 & 63,7 \\
& Educação Infantil & 26,1 & 37,1 & 51,1 \\
\hline \hline \multirow{4}{*}{ Negra } & $\mathbf{0}$ a 3 anos & 6,2 & 10,4 & 20,4 \\
& $\mathbf{4}$ a 6 anos & 50,5 & 66,9 & 85,4 \\
& Ensino Fundamental & 80,8 & 92,7 & 96,0 \\
& Ensino Médio & 12,0 & 31,9 & 49,3 \\
& Ensino Superior & 2,0 & 4,4 & 10,7 \\
\hline
\end{tabular}

Fonte: IBGE/PNAD

Elaboração: IPEA/DISOC

*a taxa de escolarização líquida fornece a proporção da população matriculada no nível de ensino considerado adequado conforme as seguintes faixas etárias: educação básica para menores de 6 anos ( 0 a 6 anos); ensino fundamental de 7 a 14 anos; ensino médio de 15 a 17 anos e ensino superior de 18 a 24 anos

${ }^{* *}$ em 2007, a duração do ensino fundamental passa a ser de 9 anos, tal como disposto na Lei $n^{\circ} 11.274 / 2006$, e as crianças de 6 anos passaram a ser incorporadas ao $1^{\circ}$ ano do ensino fundamental. Os municípios, estados e o Distrito Federal tiveram prazo até 2010 para adaptar-se a esta nova realidade.

\section{g) Previdência}

Quanto à cobertura previdenciária, houve nítidos avanços no período recente, mas persistem as desigualdades entre a população negra e branca em quase $10 \%$. Isto implica dizer que a população negra está mais exposta às oscilações do mundo do trabalho.

Quadro 9 - Cobertura Direta e Indireta da Previdência Pública na População em Idade Ativa, segundo Cor/Raça e Sexo - Brasil e Regiões, 1995 a 2013

\begin{tabular}{|c|c|c|c|c|}
\hline \multirow[t]{2}{*}{ Cor/Raça } & \multirow[t]{2}{*}{ Sexo } & \multicolumn{3}{|c|}{ Ano } \\
\hline & & 1995 & 2003 & 2013 \\
\hline \multirow{3}{*}{ Branca } & Total & 69,2 & 64,4 & 71,5 \\
\hline & Masculino & 71,3 & 66,2 & 73,0 \\
\hline & Feminino & 67,2 & 62,8 & 70,1 \\
\hline \multirow{3}{*}{ Negra } & Total & 58,5 & 53,5 & 62,2 \\
\hline & Masculino & 60,8 & 55,4 & 64,1 \\
\hline & Feminino & 56,2 & 51,7 & 60,4 \\
\hline
\end{tabular}

Fonte: IBGE/PNAD. 
Elaboração: IPEA/DISOC.

* a PNAD não foi realizada nos anos de 2000 e 2010.

**é considerada em idade ativa a população entre 10 e 59 anos de idade.

**** são considerados cobertos diretamente pela previdência pública aqueles que contribuem diretamente, os funcionários públicos, militares e empregados com carteira de trabalho assinada em qualquer trabalho na semana de referência e os segurados especiais da previdência rural.

***** são considerados cobertos indiretamente pela previdência pública os cônjuges e filhos até 21 anos de idade daqueles que são cobertos diretamente.

\section{h) Saneamento}

Importante indicador para aferir a saúde da população negra são os dados referentes a saneamento. De acordo com os dados da PNAD, 33,5\% da população negra residiam em domicílios sem esgotamento sanitário adequado. A população branca, embora também esteja exposta a falta de saneamento, não ultrapassa $20 \%$ de domicílios sem esgotamento sanitário adequado.

Quadro 10 - Proporção de Domicílios Particulares Permanentes Urbanos com Esgotamento Sanitário Adequado, segundo Cor/Raça do/a Chefe do Domicílio - Brasil e Regiões - 1995, 2003 e 2013.

\begin{tabular}{clccc}
\hline \multirow{2}{*}{ Cor/Raça } & \multirow{2}{*}{ Região } & \multicolumn{3}{c}{ Total } \\
\cline { 3 - 5 } & Brasil & $\mathbf{1 9 9 5}$ & $\mathbf{2 0 0 3}$ & $\mathbf{2 0 1 3}$ \\
\hline \hline \multirow{3}{*}{ Branca } & Norte & 70,0 & 75,2 & 80,0 \\
& Nordeste & 36,0 & 15,9 & 30,5 \\
& Sudeste & 88,1 & 46,8 & 57,8 \\
& Sul & 51,1 & 61,7 & 95,4 \\
& Centro-Oeste & 43,1 & 46,0 & 69,7 \\
& Brasil & 47,3 & 55,9 & 66,5 \\
\hline \multirow{4}{*}{ Negra } & Norte & 8,8 & 12,5 & 24,3 \\
& Nordeste & 27,9 & 41,0 & 52,1 \\
& Sudeste & 75,0 & 82,4 & 90,9 \\
& Sul & 37,2 & 53,5 & 64,9 \\
& Centro-Oeste & 34,7 & 38,1 & 50,0 \\
\hline
\end{tabular}

Fonte: IBGE/PNAD.

Elaboração: IPEA/DISOC.

* a PNAD não foi realizada nos anos de 2000 e 2010.

** em 2004 a PNAD passa a contemplar a população rural de Rondônia, Acre, Amazonas, Roraima, Pará e Amapá.

*** a população negra é composta por pretos e pardos.

**** esgotamento sanitário adequado em domicílios da área urbana: domicílios com rede coletora de esgoto ou pluvial ou domicílios com fossa séptica ligada à rede coletora. 


\section{Conclusão}

Nesse estudo, pretendeu-se enfatizar os caminhos sinuosos pelos quais se tem evidenciado uma questão intencionalmente em aberto no interior da sociedade brasileira. A estrutura da sociedade brasileira apresenta uma composição em que os obstáculos socioeconômicos, tais como pobreza, desigualdades e violência tem uma relação direta com o racismo, sobretudo com as formas miméticas do modelo racial aqui instalado.

Os diferentes aportes teóricos à compreensão da natureza do racismo não têm sido suficientes para dar a dimensão essencialista com que as atualizações racistas vêm ocorrendo. O longo percurso histórico, da escravidão negra no Brasil, terminou por estabelecer um ente não assimilável na consolidação da sociedade brasileira, sem contudo assumir o desprezo, o ódio e a rejeição de parcela de sua população.

A concepção moderna das relações sociais prescindiu de maiores explicações para estabelecimento do lugar central em que as desigualdades econômicas passaram a compor o amplo espectro das mazelas sociais. No entanto, para efeito de localização desse estudo, compreendem-se dois importantes fundamentos conceituais que procuram atestar a dualidade do 
pensamento social em torno da questão racial em todo seu processo de afirmação de uma identidade nacional.

Primeiro, a incorporação do negro na sociedade de classe não acompanhou o movimento histórico do capital. As alterações verificadas nas condições de vida do conjunto da sociedade e as novas formas políticas da dominação burguesa permitiram a manutenção da violência racial sem deixar de levar em consideração as contribuições simbólicas e culturais da população negra.

A construção de uma identidade assimilacionista em que o visto de fora (exótico) emoldurou as principais características do elemento branco, enquanto referência central de civilidade e modernidade.

Todavia esse movimento não fora capaz de forjar um padrão de poder no qual a capacidade regulatória do Estado nacional contemplasse o conjunto das expressões sociais da realidade brasileira de maneira objetiva. A escolha pelo padrão branco ficou expressa nas constituições desde 1824 a 1967, o que veio a constituir se pilares institucionais efetivados pelo padrão europeu.

O racismo em suas várias facetas terminou por compor um complexo mosaico cujas partes são historicamente refletidas nos arranjos institucionais desenvolvidos há séculos. A grave situação observada nos indicadores sociais mais atualizados confirma uma insofismável verdade. À base das relações sociais constituídas desde o século $\mathrm{XVI}$, confirma-se o racismo enquanto fundamento maior na institucionalização e estruturação das relações sociais.

As características marcantes desse padrão de relações raciais se caracterizam por um sistema classificatório no qual as características fenotípicas aparentes definem o tratamento, as relações e as obstruções aos acessos aos direitos sociais. Por outro lado, as configurações culturais decorrentes de dois mitos fundantes - o mito do branqueamento social e o mito da democracia social -, conferiram a esses arranjos um status de harmonia racial.

No entanto, alguns aspectos fundamentais saltam aos olhos de observadores mais atentos, a alegada ausência de uma cultura de ódio racial explícito, em verdade, revela uma construção ideologicamente vigorosa que teve a efetiva participação do Estado brasileiro como promotor de políticas 
públicas segregacionistas nas três fases de consolidação da nação brasileira Colônia, Império e República.

Tendo essa última fase a tarefa mais efetiva no sentido de confirmar para o mundo que aqui os desafios de uma nação integrada haviam sido superados pela engenhosa estratégia de constituir-se uma nação cuja miscigenação representou uma estratégia bem sucedida na mitigação da discriminação e do racismo, observadas em outras nações.

Ao adotar o método da teoria marxista, no transcorrer das narrativas dessa tese, pretendeu-se traçar um panorama histórico capaz de revelar as causas dos persistentes indicadores sociodemográficos negativos da população negra, bem como identificar a força motriz que mantem de forma quase inalterada as desigualdades, verificadas nos níveis das políticas sociais na saúde, educação, trabalho, dentre outras.

Não há como negar a presença majoritária negra nos piores índices de desenvolvimento humano e tratar de maneira displicente os efeitos devastadores do racismo.

Por outro lado, permeou esse trabalho, o racismo como substantivo concreto das ações institucionais da ação do Estado corroborado pelas plásticas relações cordiais entre negros e brancos.

Conquanto, a percepção desses fatores determinantes de um lugar social da segregação racial brasileira, buscou-se aliar a essa análise os fundamentos históricos do nascente capitalismo nacional, suas transformações do modo de produção e o consequente estabelecimento da divisão social em classes.

Aqui a caracterização demonstrada seguiu na direção de explicitar que a sucessão do modo de produção escravista para o modelo de produção capitalista não obedeceu a uma sequência cronológica, mas ocorreu concomitantemente, hibridizando as formas econômicas e sociais, caracterizando-as por uma composição incomum em relação aos demais países em pleno desenvolvimento do capitalismo.

$\mathrm{Na}$ constituição do projeto de nação se observa uma matriz originária das relações coloniais em que os marcadores étnico-raciais, por vezes biologizados, nutriram o imaginário nacional de reais possibilidades de uma 
incorporação de valores culturais, sem contudo possibilitar uma efetiva integração política.

De outra forma, é possível traduzir que no plano ideológico as estratégias para a consolidação da nação brasileira herdaram as raízes históricas das nações colonizadoras, em especial a lusitana, que teve no patriarcado patrimonialista e branco sua principal orientação.

Porém é marcante e decisiva as influências das teorias do racismo científico no final do século XIX, que fundamentou as determinações nacionalistas que em alguns casos (Alemanha e Itália) deram origem ao nazifacismo.

Dentro dessa linha de raciocínio, com o advento da modernidade, a inspiração igualitarista da revolução francesa irá servir de modelo de nação em que as leis estabeleceram uma constituição de princípios que passou a regular a vida social dos indivíduos a partir do princípio da igualdade, segundo Kaysel (2011).

Importa aqui a reafirmação de que os elementos que estruturaram e balizaram as relações econômicas e sociais no passado trouxeram implicações de difícil solução quanto a aplicação do igualitarismo.

Os arranjos pretéritos na consolidação do capitalismo industrial e a instalação das concepções de Estado moderno não permitiram a adoção de soluções para a questão racial.

Em síntese, o modelo desenvolvimentista inserido no capitalismo de Estado se apresenta inexoravelmente como incompatível com as exigências de integração do enorme contingente populacional negro.

Dessa forma, uma possível conclusão é de que a questão se mantém em aberto, primeiro porque não foi objeto de preocupações quanto as contradições internas decorrentes do anacronismo da escravidão em compatibilidade com o nascente capitalismo.

Depois, porque essas teorias racistas nascidas no bojo dos Estados nacionalistas sedimentaram aqui um determinismo racial em que o conjunto da população negra não teria as condições cognitivas para uma adequação ao modelo de desenvolvimento em curso na atualidade.

No entendimento desse trabalho, o mito da democracia racial se atualiza quando o debate não avança para além das constatações das 
assimetrias existente entre negros e brancos. Mesmo quando há na atualidade vastos indicadores recortado por raça/cor, ainda assim os gestores assumem uma discricionariedade capaz de negar o mais óbvio desses indicadores sob a alegação de que a não existência de um modelo binário de classificação racial compõe o imaginário social.

Nesse sentido, a adoção do método de análise marxista, possibilitou alcançar ainda de maneira tênue alguns detalhes do processo do desenvolvimento da nação brasileira, que ciclicamente se repete na reificação de uma sociedade estratificada cujos elementos estruturadores deitam raízes nas diferenças étnico-raciais.

A espiral, em suas repetidas voltas, aponta inexoravelmente para os fenômenos sociais ocorridos na superação das etapas passadas, no entanto parece manter-se inalterada a sustentação do racismo enquanto elemento da superestrutura definida por Marx:

\begin{abstract}
$\mathrm{Na}$ produção social de sua vida, os homens contraem relações determinadas, necessárias e independentes da sua vontade, relações de produção estas que correspondem a uma determinada etapa de desenvolvimento das suas forças produtivas materiais. A totalidade destas relações de produção forma a estrutura econômica da sociedade, a base real sobre a qual se ergue a superestrutura jurídica e política, e à qual correspondem formas sociais determinadas de consciência. $O$ modo de produção da vida material condiciona $O$ processo em geral de vida social, política e espiritual. (MARX, 2006, p.25)
\end{abstract}

Os diferentes caminhos pelos quais optamos percorrer, sinalizam uma necessidade de adensar elementos para a reflexão em torno do debate ainda pouco explorado das relações raciais e o processo civilizatório na conformação atual do pensamento social brasileiro.

Longe de ter uma pretensão maior do que apontar algumas possíveis perspectivas, esse estudo pretendeu contribuir na compreensão do papel central que as relações raciais e o racismo, enquanto elemento estruturante, ainda desempenham na sustentação para um debate parcial no tocante ao papel da escravidão na configuração do modelo social e econômico, que insiste em trilhar o caminho da ideologia de negação do racismo. 
Interessa-nos pois estabelecer uma perspectiva de considerar a evolução das relações produtivas no Brasil com base nas primeiras investidas europeias na expansão territorial e nas protoformas do que viria a ser as linhas mestras do capitalismo peculiar com que lidamos na atualidade.

A persistente invisibilização da questão racial nos debates em torno da modernização e do desenvolvimento econômico traduz a determinação em tratar as questões relacionadas a desigualdades e pobreza, como parte de um processo natural de evolução social, sem que as caraterísticas marcantes da escravidão sejam colocadas em debate.

As funções integrativas da dominação europeia $e$ as bases do capitalismo formaram uma bem sedimentada ideologia na qual o sistema social de poder, no decorrer do largo período colonial e imperial, reafirmou a ordem escravocrata.

Em seguida, com a emergência da nascente república, estabeleceu-se uma ordem social competitiva, sem contudo permitir formalmente o ingresso de uma grande massa de negros. (FERNANDES, 2004, p.365)

Ao nosso entendimento, o debate racial, no âmbito das ciências sociais, tem melhorado quanto a abordagem do tema, mas sua inserção ainda se mostra frágil por estabelecer paradoxos imaginários entre o econômico e 0 social.

Os fundamentos que caracterizam uma aproximação conceitual, estabelecidos por uma nova institucionalidade da questão racial, ante as demandas desse contingente populacional majoritário dentro da realidade brasileira, conferem prioridade ao explicitar da natureza problemática da junção de raça e classe enquanto categorias essenciais das análises sociais do país:

De acordo com uma ou outra dessas perspectivas, o funcionamento e o rendimento da escravidão são vistos como contraparte de um contexto histórico-estrutural regulador e determinante. Se se constrói o contexto histórico estrutural a partir do sistema de produção e de dominação econômica, o que ganha saliência são as funções econômicas da escravidão, que variam ao longo da evolução apontada. Se se constrói o contexto histórico estrutural a partir do sistema social de poder (e portanto de dominação política), o que ganha saliência são as funções sociais da escravidão, que variam menos mas, ainda assim, também sofrem transformações ao longo da evolução apontada. Em um tratamento analítico exaustivo, a primeira modalidade de reconstrução teria de passar da base econômica as estruturas sociais de poder (ou "as superestruturas dos sistemas"), para que o quadro ficasse completo. E reciprocamente, a 
segunda modalidade de reconstrução teria de abranger, forçosamente, as determinações e as implicações da base econômica sobre o sistema social de poder e de dominação política." (FERNANDES, 2004, p.366.)

Desta forma, a luta antirracista termina por se inserir nas determinações das captações teóricas do debate em torno do processo originário civilizatório nacional, tendo como epicentro dois movimentos simultâneos: a consolidação de uma sociedade que se constitui a partir da imigração de trabalhadores europeus, e a migração do capital mercantil e consequente fortalecimento de uma classe burguesa local.

As representações sociais dos períodos estudados levam as análises para um campo em que a importância que se deu ao tema da questão racial é secundarizada por uma perseguição dos ideais modernizantes e do alinhamento das atividades econômicas e, por conseguinte, do crescimento econômico.

Com isso, percebe-se um distanciamento das investigações quanto ao papel-chave do lugar do negro na sociedade. Esse silêncio, por vezes injustificado, sob a alegação de uma neutralidade comprometedora, limita significativamente o olhar sobre as raízes das desigualdades sociais de cariz racial.

No decorrer desse estudo discorremos sobre os principais períodos em que se fez necessário um debruçar-se em torno dos movimentos contínuos da institucionalidade da questão. Em uma primeira visão, percebe-se que não foram suficientemente explorados os momentos de inflexão para o debate racial.

A relevância histórica das especificidades das relações capitalistas no Brasil, sem a observância as múltiplas determinações desse processo, contribuiu para retardar a elucidação das ambivalências que comumente ocorrem ao analisar a luta de classes e inserir a categoria racial.

O marco histórico verificado na passagem das etapas que compreendem os interstícios da colônia, e sobretudo entre o império e a república, revela intensos debates para inserção da luta da população negra, impondo uma alteração nas formas políticas da dominação burguesa no país. 
A omissão quanto ao papel preponderante do racismo reside na formulação dispersa em torno desse conceito e suas implicações práticas; de outra forma, a sociedade brasileira, assimilou as noções racialistas com e a partir das diferenças, mas sobretudo pelas condições concretas daqueles que vieram em condição distinta ao trabalho livre, portadores de livre acesso ao trabalho livre

Para melhor caracterizar o conceito de racismo, tão em voga nos debates mas ainda muito distante de sua complexa e variada definição, utilizaremos as definições categoriais do racismo a partir de Taguieff (1997):

Trata-se, para nós, de responder à questão falsamente simples: como se coloca hoje o problema do racismo? Tentar responder-Ihe, equivale a comprometer-nos a repensar o racismo mas também o antirracismo. No prefácio de A Fenomenologia do espirito(1807), Hegel lança uma advertência altamente filosófica, sob forma de um quase jogo de palavras: "Geralmente, o que é conhecido, justamente porque é bem conhecido, não é conhecido." O bem conhecido racismo não é por isso conhecido. Nem o estudo do racismo nem luta contra as suas formas atuais poderão basear-se simplesmente numa definição do tipo: "O racismo é a doutrina que assenta na afirmação de uma hierarquia entre as raças humanas". (TAGUIEFF, 1997, p.7)

O autor acima citado traduz os dilemas de tratar as implicações do racismo nas formulações políticas de constituição das relações sociais e por conseguinte do uso político que se faz do conceito, para o bem ou para o mal.

Nesse trabalho, a recuperação conceitual segue na confrontação necessária em traduzir as primeiras percepções do racismo enquanto fundamento cientifico do século XIX, e suas implicações para a realidade da então colônia.

De outra forma, igualmente importante é caracterizá-lo enquanto abstrações prejudiciais muitas das vezes indutoras de neutralidades axiológicas do pensamento social brasileiro. Interessa-nos trazer as constantes ressemantizações que vem acompanhando o termo tanto no que diz respeito ao sentido político empregado como na perspectiva mítica do tabu em trazê-lo para o campo das formulações das políticas atuais de discriminação positiva.

Segundo Taguieff (1997, p.67), os comportamentos racistas não se revelam apenas nas dimensões das atitudes, das opiniões ou das xenofobias, eles podem produzir efeitos que necessariamente não estão em consonância 
com essas vertentes mensuráveis, mas podem atuar no inconsciente coletivo pelo qual as dimensões pré-conhecidas não necessariamente atuam.

Por outro lado, o racismo, não só é operacionalizado biologicamente com referências a raça. Para tanto, o autor faz distinção entre o racismo biológico ${ }^{28}$ e o racismo cultural, ressaltado seu caráter clássico no qual a cor da pele, tamanho, forma do crânio dentre outros aspectos são determinações a serem levadas em conta nas diferenças humanas.

$O$ argumento que nos interessa com ênfase para esse momento é o que Taguieff desenvolve:

[...] convém distinguir o racismo de exploração (o racismo colonial, escravista, imperialista, etc.) - explicável pela teoria marxista ou pela da escolha racional - e o racismo de exterminação, que, para além de todo o cálculo racional de interesses econômicos, preconiza o aniquilamento total de um grupo humano (como o semitismo genocida de tipo nacional-socialista). O primeiro põe em jogo uma desigualdade entre raças julgadas superiores e inferiores, tendendo a desumanizar ou a animalizar as raças inferiorizadas, e concede direitos superiores às raças superiores, legitimando assim o proveito tirado da exploração das raças ditas inferiores. (TAGUIEFF, 1997, p.70).

Nesse ponto, retornamos as reflexões do trabalho ao sinalizar que, em função dos derivados das vertentes do colonialismo até os dias atuais, o debate em torno das ações afirmativas expõe algumas questões de ordem prática quanto a análise das referidas políticas e das tradicionais políticas públicas.

Ao tratar com especificidade as políticas raciais, a inflexão com que o debate se irradia segue na direção das práticas individualizadas do racismo cultural e biológico, todavia as abstrações para negação de um fato que confere relevância ao debate não estão circunscritas em apenas duas tipologias, mas no engendramento dessas com as dimensões reparadoras de políticas de Estado.

Dito de outra forma, nas atuais configurações dos debates raciais, por um lado, questiona-se a legitimidade dos movimentos sociais negros em caracterizar o racismo enquanto obstáculo central, propondo assim a revisão

${ }_{28}$ Racismo biológico - racismo clássico, baseia-se nos caracteres somáticos (cor da pele, tamanho, forma do crânio etc. Racismo Cultural - pseudo-racismo ou neo-racismo - baseia-se nas explicações do curso da história o0u do funcionamento social em categorizações elaboradas a partir de características culturais (costumes, língua, religião etc.). (TAGUIEFF, 1997, p. 68-69). 
do conjunto da sociedade quanto aos benefícios auferidos com base na escravidão e sua consequência direta a discriminação racial.

Por outro lado, na defesa dos interesses nacionais, elogia-se a dimensão coletiva de ascensão ao desenvolvimento econômico sem contudo reconhecer e reparar as hierarquias pretéritas que ensejaram as desigualdades verificadas de forma mais severas nas populações negras.

Diante do esforço empreendido na elaboração dos estudos dessa tese, uma eventual conclusão que nos permitimos formular é de que, no longo período compreendido desde a colônia até o momento atual, as oscilações entre a incorporação e integração da população negra no processo civilizatório nacional tiveram na incorporação a forma mais adequada aos interesses de uma nação que se pretendeu sempre de cariz europeu.

Uma outra possibilidade de aproveitamento conclusivo é de que o determinismo econômico sempre esteve a espreitar as movimentações do Estado-nação quando se tratou de questionar o que fazer com a massas de negros.

$\mathrm{Na}$ atualidade não nos parece haver em curso um movimento revolucionário capaz de mudar as perspectivas de uma repactuação em torno da construção de um projeto de nação em que a dimensão racial passe a ter relevância, se não pelo apreço às particularidades étnico-raciais, quando muito pela capacidade produtiva negada dentro do mundo das coisas a esse contingente majoritário numericamente falando.

À deriva entre o carisma do governante e as políticas pontuais e emergenciais, a questão racial conserva o caráter estruturante de relações sociais iníquas cujos sinais afloram com mais frequência no noticiário jornalístico que nas elucubrações de nossa cultura política. 


\section{REFERÊNCIAS}

ARICÓ, José. Marx e a América Latina. Rio de Janeiro: Paz e Terra, 1982.

BASTIDE, Roger. El Positivismo Brasileño y la Incorporación del Proletariado de Color a la Civilización Occidental. Revista Mexicana de Sociologia. Vol.8, oo3 (sep.-dec. 1946), p. 371-388.

BERMÚDEZ S., Maillyng. Silencio y exclusión: la afrovenezolanidad tras la sombra - una perspectiva desde la enseñanza de la historia. Caracas: Fundación Editorial El perro e larana, 2009. 
BESOUCHET, Lídia. História da Criação do Ministério do Trabalho. Rio de Janeiro: Departamento de Informação do M.T.C.I., S/d.

BORÓN. Atílio. A Coruja de Minerva: mercado contra democracia no capitalismo contemporâneo. Petrópolis: Vozes, 2001.

BOSCHETTI, Ivanete. Seguridade Social e Trabalho: Paradoxos na Construção das Políticas de previdência e Assistência Social. Brasília: Editora da Universidade de Brasília e Editora Letras Livres, 2006.

Assistência Social no Brasil: um Direito entre a Originalidade e Conservadorismo. Brasília, Ivanete Boschetti, 2001;

CASTEL, Robert. A Nova Questão Social. Petrópolis: Vozes, 2001.

CIMADAMORE, A.; DEAN, H.; SIQUEIRA, J. (orgs). A Pobreza do Estado - Reconsiderando o papel do estado na luta contra a pobreza global. Buenos Aires: CLACSO, 2006.

COORDENAÇÃO NACIONAL DE ENTIDADES NEGRAS. Marcha à Brasília por uma política de combate ao racismo e à desigualdade social. São Paulo: Coordenação de Entidades Negras, 1995.

CRESWELL, John W. Projeto de pesquisa - métodos qualitativos, quantitativo e misto. Tradução: Luciana de Oliveira da Rocha. Porto Alegre: Artmed, 2007.

DAGNINO, Evelina (org.). Anos 90 - política e Sociedade no Brasil. São Paulo: Brasiliense, 1994.

DAGNINO, Evelina; ESCOBAL, Artur (org.) Cultura e Política nos Movimentos Sociais Latino-americanos: novas leituras. Belo Horizonte: UFMG, 2000. 
DAGNINO, Evelina; OLIVERA, Alberto J.; PANFICHI, Aldo (Orgs.) $A$ Disputa pela Construção Democrática na América Latina. Campinas-SP: Ed. Unicamp, 2006.

DENZIN, N. K., LINCOLN, Y. S. \& colaboradores. O planejamento da pesquisa qualitativa - teorias e abordagens; tradução: Sandra Regina Netz. Porto Alegre: Artmed, 2006.

DJICK, Teun A. van (org.). Racismo e Discurso na América Latina. São Paulo: Contexto, 2008.

DOIMO, Ana Maria. A Vez e a Voz do Popular: solidariedade, movimentos sociais e participação política no Brasil pós-70. Rio de Janeiro: Relume Dumará, 1995.

FANON, Frantz. Pele Negra e Máscaras Brancas. Salvador: Editora Fator: Outra Gente, 1983.

. Os Condenados da Terra. Tradução: Enilce Albergaria Rocha e Lucy Magalhães. Juiz de Fora-MG: Ed. UFJF, 2005. (Coleção Cultura, v.2)

FERNANDES, Florestan. A Integração do Negro na Sociedade de Classes. São Paulo: Ática, 1978.

. Poder e Contrapoder na América Latina. Rio de Janeiro: Zahar Editores, 1981.

FERNÁNDEZ, Arturo; LESGART, Cecilia (orgs.). La democracia em América Latina: partidos políticos e movimentos sociales. Rosário: Homo Sapiens Ediciones, 2008.

FREYRE, Gilberto. Casa Grande e Senzala. 100 anos de Gilberto Freyre. $39^{a}$ ed. Rio de Janeiro: Editora Record, 2000. 
FURTADO, Celso. Formação Econômica do Brasil. São Paulo: Ed. Companhia das Letras, 2007.

GOHN, Maria da Glória; BRINGEL, Breno M.(Orgs). Movimentos Sociais na era Global. Petrópolis, RJ: Vozes, 2012.

GONÇALVES, Reinaldo. Vagão Descarrilhado: O Brasil e o Futuro da Economia Global. Rio de Janeiro: Ed. Record. 2002.

GIDDENS, Anthony (Orgs.) O Debate Global sobre a Terceira Via. Trad. Roger Maoli dos Santos. São Paulo: Ed. UNESP, 2007.

GUIMARÃES, Antônio Sérgio Alfredo. Classes, Raças e Democracia. São Paulo: Editora 34, 2002.

HARVEY, David. O Neoliberalismo: História e Implicações. São Paulo: Ed. Loyola, 2008.

HOLSTON, James. Cidadania Insurgente: Disjunções da Democracia e da Modernidade no Brasil; Trad. Claudio Carina. São Paulo: Companhia das Letras, 2003.

IANNI, Octávio. Raças e Classes Sociais no Brasil. Rio de Janeiro: Ed. Civilização Brasileira, 1972.

. Estado e Capitalismo. São Paulo: Ed. Brasiliense, 2004.

As metamorfoses do Escravo. $2^{\mathrm{a}} \mathrm{ed}$. Revista e Aumentada. São Paulo: Hucitec; Curitiba: Scientia et Labor, 1988.

IVO, Anete Brito Leal. A Reconversão da Questão Social e a Retórica da Pobreza. In: CIMADAMORE, A.; DEAN, H.; SIQUEIRA, J. (orgs). A Pobreza do Estado - Reconsiderando o papel do estado na luta contra a pobreza global. Buenos Aires: CLACSO, 2006. 
JACCOUD, Luciana (org.). Questão Social e Políticas Sociais no Brasil Contemporâneo. Brasília: IPEA, 2005.

JEAN, Lojkine. O Estado Capitalista e a Questão Urbana. Trad. Estela dos Santos Abreu, 2를. São Paulo: Martins Fontes, 1997.

LAGO, Luiz Aranha Corrêa do. Da escravidão ao trabalho livre. Brasil, 1550-1900. São Paulo: Companhia das Letras, 2014.

LESSA, Sérgio; TONET, Ivo. Introdução à Filosofia de Marx. São Paulo: Expressão Popular, 2008.

LUKÁCS, G. Ontologia do ser Social: os princípios ontológicos fundamentais de Marx. São Paulo, Ciências Humanas, 1979.

MACHADO DE ASSIS, J.M. A Reforma pelo Jornal. Disponível em: < http://machado.mec.gov.br/images/stories/pdf/cronica/macr14.pdf $>$. Acesso em 03/08/2005.

Bons dias! Disponível em: http://machado.mec.gov.br/images/stories/pdf/cronica/macr11.pdf>. Acesso em: 03/08/2005.

MARX, Karl. O Capital: Crítica da Economia Política: Livro I. 25ª Ed. Rio de Janeiro: Civilização Brasileira, 2008.

Para a Crítica da Economia Política. Trad. Leonardo de Deus, Belo Horizonte: Ed. Autentica, 2010.

MARX, Karl; ENGELS, Friedrich. A Ideologia Alemã. São Paulo: Ed. Martin Claret, 2006.

MASSON, Gisele. As contribuições do método materialista histórico e dialético para a pesquisa sobre políticas educacionais. UEPG, Acesso internet em 02/04/2013. 
MOURA, Clovis, Dicionário da Escravidão Negra no Brasil. São Paulo: Ed. Universidade de São Paulo, 2004.

MUNANGA, Kabengele. As facetas de um racismo silenciado. In: Raça e diversidade. SCHWARCZ, Lília Moritz; QUEIROZ, Renato da Silva (orgs). São Paulo: EDUSP, 1996, pp. 213-229.

. Rediscutindo a Mestiçagem no Brasil - Identidade Nacional versus Identidade Negra. Rio de Janeiro, Ed. Vozes, 1999.

NEVES, Marcelo. Estado Democrático de Direito e Discriminação Positiva: um Desafio para o Brasil. In: SOUZA, Jessé (org.) Anais do Seminário Internacional Multiculturalismo e Racismo: o Papel da Ação Afirmativa nos Estados Democráticos Contemporâneos. Brasília, 1997;

NEVES, Rômulo Figueira. Cultura política e elementos de análise da política venezuelana. Brasília: FUNAG, 2010.

PAULO, Carlos Alberto Santos de. Movimento Negro, Participação e Institucionalidade: desafios para uma agenda pública. Mestrado em Política Social. Universidade de Brasília, 2002.

PEREIRA, Potyara A. P. Política Social - temas \& questões. São Paulo: Cortez, CNPq, 2008.

A Assistência Social na Perspectiva dos Direitos: Crítica aos Padrões Dominantes de Proteção aos Pobres no Brasil. Brasília, Thesaurus, 1996.

PAIXÃO, Marcelo; CARVANO, Luiz M.(org.). Relatório Anual das Desigualdades Raciais no Brasil - 2007/2008. Rio de Janeiro: Ed. Garamond Ltda, 2008.

Relatório Anual das Desigualdades Raciais no Brasil 2009/2010. Rio de Janeiro: Ed. Garamond Ltda, 2008. 
PAIXÃO, Marcelo. A Lenda da Modernidade Encantada: por uma crítica ao pensamento social brasileiro sobre relações raciais e projeto de Estado/nação Curitiba: CRV, 2014.

PATTERSON, Orlando. Escravidão e Morte Social: Um estudo Comparativo; trad. Fábio Duarte Joly. São Paulo: Ed. Universidade de São Paulo, 2008.

PIOVESAN, Flávia; MARTINS, Douglas (coord.) Ordem Jurídica e Igualdade Étnico-Racial. Brasília: Secretaria de Políticas de Promoção da Igualdade Racial - Presidência da República, 2006.

PORTO, Maria Stela Grossi; DWYER, Tom P. (orgs.). Sociologia e Realidade - pesquisa social no século XXI. Brasília: Editora Universidade de Brasília, 2006.

POULANTZAS, Nicos. O Estado, o Poder e o Socialismo. Rio de Janeiro: Edições Graal, 1980.

O Estado em Crise. Rio de Janeiro: Edições Graal, 1977.

RELATÓRIO DE DESENVOLVIMENTO HUMANO. Racismo, Pobreza e Violência. Programa das Nações Unidas para o Desenvolvimento PNUD/Brasil, Brasília, 2005

RENAULT, Emanuel. Vocabulário de Marx. Trad. Claudia Berliner. São Paulo: Ed. Martins Fontes, 2010.

REVISTA SERVIÇO SOCIAL E SOCIEDADE. Espaço Público, Cidadania, Terceiro Setor, no 59, Ano XX. São Paulo: Cortez, março / 1999.

REVISTA SOCIEDADE E ESTADO. O Estado em Questão: Teoria e Prática. Departamento de Sociologia, Universidade de Brasília. Vol. VI (2) jul/dez. 1991 - Brasília: Editora Universidade de Brasília, 1986. 
REVISTA DE SOCIOLOGIA DA USP. TEMPO SOCIAL, V.11, № 2 (out/1999) São Paulo, USP, FFLCH, 1989.

SAMPAIO JUNIOR, Plínio de Arruda. Desenvolvimentismo e neodesenvolvimentismo: tragédia e farsa. Disponível em: $<$ http://www.scielo.br/pdf/sssoc/n112/04.pdf $>$. Acesso 24 jan. 2015.

SILVERMAN. David. Interpretação de dados qualitativos - métodos para análise de entrevistas, textos e interações; tradução: Magda França Lopes. Porto Alegre: Artmed, 2006.

SORIANO, Raul Rojas. Manual de pesquisa social; tradução: Ricardo Rosenbusch. Petrópolis (RJ): Vozes, 2004

TAGUIEFF, Pierre-André. O Racismo; trad. José Luís Godinho. Lisboa: Instituto Piaget, 1997.

TELLES, Edward. Racismo à Brasileira - uma nova perspectiva sociológica. Rio de Janeiro: Relume Dumará, Fundação Ford, 2003.

THEODORO, Mario; JACCOUD, Luciana. OSÓRIO, Rafael; SUAREZ, Sergei (orgs.). As Políticas Públicas e a Desigualdade Racial no Brasil: 120 anos após a Abolição. Brasília: IPEA, 2008.

VIANNA, Luiz Werneck. Esquerda Brasileira e Tradição Republicana: Estudos de Conjuntura sobre a era FHC - Lula. Rio de Janeiro: Ed. Revan, 2006.

VENTURA, Roberto. Estilo Tropical: história cultural e polêmicas literárias no Brasil, 1870-1914. São Paulo: Companhia das Letras, 1991.

VIDA, Samuel. O racismo institucional e as ações afirmativas enquanto dever do Estado. In: FUNDAÇÃO CULTURAL PALMARES. O Negro no 
Mercado de Trabalho. Brasília: Ministério do Trabalho e Emprego: Ministério da Cultura, 2005.

VIEGAS, Waldyr. Fundamentos de metodologia científica. Brasília: Paralelo 15: Editora Universidade de Brasília, 1999. 